\title{
EXCEPTIONAL EXAMPLES OF THE MASTERS OF ETCHING AND ENGRAVING
}

THE PRINT COLLECTION OF THE LATE

J. HARSEN PURDY, OF NEW YORK CITY

TO BE SOLD AT UNRESTRICTED PUBLIC SALE ON TUESDAY AND WEDNESDAY EVENINGS

APRIL 10TH AND 11TH, 1917

UNDER THE MANAGEMENT OF THE AMERICAN ART ASSOCIATION

AMERICAN ART GALLERIES

MADISON SQUARE SOUTH

NEW YORK CITY 

SMITH*ONIAN

IIITITUTION

$$
3119 \text {. }
$$



THE AMERICAN ART ASSOCIATION DESIGNS ITS CATALOGUES AND DIRECTS ALL DETAILS OF ILLUSTRATION TEXT AND TYPOGRAPHY 



\author{
ON PUBLIC EXHIBITION \\ AT THE AMERICAN ART GALLERIES \\ MADISON SQUARE SOUTH, NEW YORK \\ ENTRANCE, 6 EAST 23RD STREET \\ BEGINNING THURSDAY, APRIL 5TH, 1917
}

\title{
MASTERPIECES OF ENGRAVERS AND ETCHERS \\ THE PRINT COLLECTION OF THE LATE \\ J. HARSEN PURDY, OF NEW YORK CITY
}

TO BE SOLD AT UNRESTRICTED PUBLIC SALE

BY ORDER OF ALBERT W. PROSS, ESQ., AND

THE NEW YORK TRUST COMPANY, AS EXECUTORS

ON TUESDAY AND WEDNESDAY EVENINGS

APRIL 10TH AND 11TH, 1917

AT 8:00 O'CLOCK IN THE EVENINGS

AT THE AMERICAN ART GALLERIES 




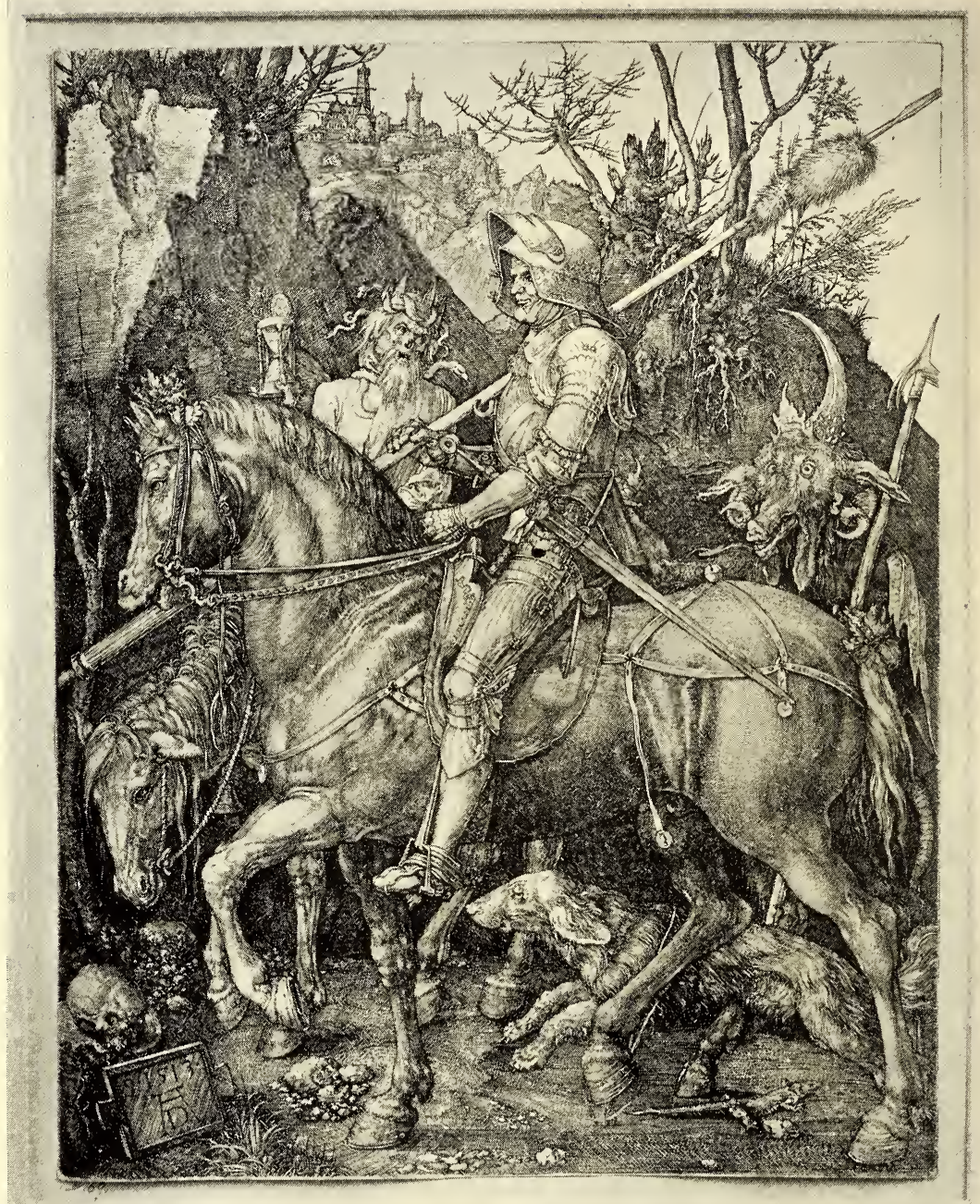

\section{ALBRECH'T DÜRER. ENGRAVING}

Knight, Death and the Devil

[No. 69] 


\section{EXCEPTIONAL EXAMPLES OF THE MASTERS OF ETCHING AND ENGRAVING}

THE PRINT COLLECTION OF THE LATE

J. HARSEN PURDY, OF NEW YORK CITY

TO BE SOLD AT UNRESTRICTED PUBLIC SALE

BY ORDER OF ALBERT W. PROSS, ESQ., AND

THE NEW YORK TRUST COMPANY, AS EXECUTORS

ON TUESDAY AND WEDNESDAY, APRIL 10TH AND 11TH AT 8:00 O'CLOCK IN THE EVENINGS

THE SALE TO BE CONDUCTED BY

MR. THOMAS E. KIRBY AND HIS ASSISTANTS, OF

THE AMERICAN ART ASSOCIATION, MANAgERS

NEW YORK CITY

1917 



\section{INTRODUCTORY NOTICE REGARDING THE PRINT- COLLECTION OF THE LATE MR. J. HARSEN PURDY OF NEW YORK CITY}

In collecting the engravings and etchings herein described, the late Mr. Purdy showed the same clear judgment and keen desire to procure only the best obtainable copies as he displayed in the choice of his library. The "Masters" who interested him most were of various schools, and date, from the latter part of the fifteenth century, when Albrecht Dürer reigned supreme among the German engravers, down through the highest development of the art of English portrait engraving in mezzotint, to the modern "Master" of etchers-James Abbott McNeill Whistler.

Many of the plates are in "Collector's" state, including proofs BEFORE ALL LETTERS and SIGNED ARTIST'S PROOFs, the impressions in most cases being of unUSUAL BRILLIANCY.

Among the more noted examples of the works of Albrecht Dürer are beautiful impressions of:-“St. Jerome in His Cell,", one of the choicest pieces of the Collection; "Knight, Death and the Devil;" "Virgin with Long Hair;" "St. George Standing;" "The Dream;" "The Standard Bearer;" "Effects of Jealousy;" "Coat of Arms with the Cock;" and "Coat of Arms with the Scull."

ANDREA MANTEGNA'S plate of "The Battle of the Sea-Gods," a beautiful impression, showing plate-mark and margins on all sides, can perhaps be classed as the "Gem of the collection," being an absolutely unique impression.

REMBRANDT VAN RIJN is represented by several etchings, including fine impression of-“The Triumph of Mordecai," "View of Amsterdam;" and "Rembrandt and Saskia."

Among the more noted mezzotint engravers and their work, the following bear special mention,-William Dickinson's "Mrs. Groynne and Mrs. Bunbury;" beautiful impression of the first state; Jонх Finlayson's “William Drummond," and "Maria, Duchess of Gloucester," both beautiful impressions of the first state; Joнn Jones's "James Boswell" and "Black Monday," the latter, an open-Letter proof; George 
Keating's "Nurse and Children in the Field;" John Sinon's "Philip, Earl of Chesterfield," "John Milton," and "Mrs. Oldfield;" Char Les Turner's "London from Greenwich," a beautiful impression over the original etching by J. M. W. Turner; James Watson's "Frances, Lady Bridges," and "Samuel Johnson;" and Thомаs Watsox's "Frances, Duchess of Richmond."

JAMES ABBO'TT MCNEILL WHISTLER is represented by three charming plates, all beautiful impressions,-_"The Limeburner," first state; "Rotherhithe," second state, and "Battersea Bridge," fourth state, with the "Butterfly" signature.

Attention is also called to the works of Francesco Bartolozzi, John Dean, Sir Francis Seymour Haden, Alexander Herman Haig, George Keating, Charles Meryon, Jean François Millet, John Ogborne, Marc Antonio Raimondi, William Walker and Jerome Wierix. The present collection containing one or more beautiful examples of each artist.

The charming mezzotint portraits of Nell Gwyn, engraved by Peter Van Bleeck, John Ogborne, Jan Verkolje, G. Valeck, A. de Blois, and Gerard Volck are also important items of the collection. 



\section{Conditions of Sale}

1. Any bid which is merely a nominal or fractional advance may be rejected by the auctioneer, if, in his judgment, such bid would be likely to affect the sale injuriously.

2. The highest bidder shall be the buyer, and if any dispute arise between two or more bidders, the auctioneer shall either decide the same or put up for re-sale the lot so in dispute.

3. Payment shall be made of all or such part of the purchase money as may be required, and the names and addresses of the purchasers shall be given immediately on the sale of every lot, in default of which the lot so purchased shall be immediately put up again and re-sold.

Payment of that part of the purchase money not made at the time of sale, shall be made within ten days thereafter, in default of which the undersigned may either continue to hold the lots at the risk of the purchaser and take such action as may be necessary for the enforcement of the sale, or may at public or private sale, and without other than this notice, re-sell the lots for the benefit of such purchaser, and the deficiency (if any) arising from such re-sale, shall be a charge against such purchaser.

4. Delivery of any purchase will be made only upon payment of the total amount due for all purchases at the sale.

Deliveries will be made on sales days between the hours of $9 \mathrm{~A}$. M. and $1 \mathrm{P}$. M., and on other days-except holidays-between the hours of 9 A. M. and 5 P. M.

Delivery of any purchase will be made only at the American Art Galleries, or other place of sale, as the case may be, and only on presenting the bill of purchase.

Delivery may be made, at the discretion of the Association, of any purchase during the session of the sale at which it was sold.

5. Shipping, boxing or wrapping of purchases is a business in which the Association is in no wise engaged, and will not be performed by the Association for purchasers. The Association will, however, afford to purchasers every facility for employing at current and reasonable rates carriers and packers ; doing so, however, without any assumption of responsibility on its part for the acts and charges of the parties engaged for such service.

6. Storage of any purchase shall be at the sole risk of the purchaser. Title passes upon the fall of the auctioneer's hammer, and thereafter, while the Association will exercise due caution in caring for and delivering such purchase, it will not hold itself responsible if such purchase be lost, stolen, damaged or destroyed.

Storage charges will be made upon all purchases not removed within ten days from the date of the sale thereof.

7. Guarantee is not made either by the owner or the Association of the cor rectness of the description, genuineness or authenticity of any lot, and no sale will be set aside on account of any incorrectness, error of cataloguing, or any imperfection not noted. Every lot is on public exhibition one or more days prior to its sale, after which it is sold "as is" and without recourse.

The Association exercises great care to catalogue every lot correctly, and will give consideration to the opinion of any trustworthy expert to the effect that any lot has been incorrectly catalogued, and, in its judgment, may either sell the lot as catalogued or make mention of the opinion of such expert, who thereby would become responsible for such damage as might result were his opinion without proper foundation.

SPECIAL NOTICE.

Buying or bidding by the Association for responsible parties on orders trans mitted to it by mail, telegraph or telephone, will be faithfully attended to without charge or commission. Any purchase so made will be subject to the above Conditions of Sale, which cannot in any manner be modified. The Association, however, in the event of making a purchase of a lot consisting of one or more books for a purchaser who has not, through himself or his agent, been present at the exhibition or sale, will permit such lot to be returned within ten days from the date of sale, and the purchase money will be returned, if the lot in any material manner differs from its catalogue description.

Orders for execution by the Association should be written and given with such plainness as to leave no room for misunderstanding. Not only should the lot number be given, but also the title, and bids should be stated to be so much for the lot, and when the lot consists of one or more volumes of books or objects of art, the bid per volume or piece should also be stated. If the one transmitting the order is unknown to the Association, a denosit should be sent or reference submitted. Shipping directions should also be given.

Priced copies of the catalogue of any sale, or any session thereof, will be furnished by the Association at a reasonable charge. 


\section{At The American Art Galleries MADISON SQUARE SOUTH, NEW YORK \\ UNRESTRICTED PUBLIC SALE, BY ORDER OF ALBERT W. PROSS, ESQ., AND THE NEW YORK TRUST COMPANY, AS EXECUTORS \\ First Session, Numbers 1 to 199, inclusive}

TUESDAY E VE N ING, A PRIL $10 \mathrm{th}$, A T $8: 00$ O, C L O C K

\section{CAREL ALLARD}

Engraver and printseller, executed a number of mezzotint portraits of English celebrities. He flourished in Amsterdam at the end of the 17th and beginning of the 18th Centuries.

\section{ALLARD, CAREL}

1. Madame Davis. Mezzotint.

Not in Smith.

Engraved after the painting by Sir Peter Lely. Fine IMPREssion with letters. Surface and condition perfect.

Cut on the plate-mark.

\section{ALBRECH'T AL'TDORFER}

One of the "Little Masters." Born at Ratisbon, 1480; died there, 1538. The oldest artist in the group of "Little Masters," and the least dependent on Dürer in the formation of his style.

\section{ALTDORFER, ALBRECHT}

2. Martin Luther. Engraving.

Bartsch, No. 61.

Signed on the plate with the monogram-"A.A." Fine IMPRESSION IN PERfECT Condition. Cut outside the plate-mark.

Duplicate from the Berlin Museum. 
First Session, Tuesday Evening, A pril 10th

\section{BENOI'T AUDRAN}

Second son of Germain Audran; born at Lyons, 1661. First received instructions from his father, afterwards studied under his uncle, Gérard Audran. Entered the "Academy" in 1709.

\section{AUDRAN, BENOIT}

3. Le Passe Temps. Engraving.

Engraved after the painting by A. Watteau. Lettered impression. IN PERFECT CONDITION AND WITH FULI. MARGINS.

\section{FRANCESCO BAR'TOLOZZI}

Borm in Florence, 1727; died in Lisbon, March 7, 1815. Pupil of Joseph Wagner at Venice. Removed to London, and founded the "Royal Academy," being nominated as one of the original members.

\section{BARTOLOZZI, FRANCESCO}

4. A St. Giles Benutr. Stipple Engraving.

Engraved after the painting by J. H. Benwell. Proof BEFORE TITLE, and with the address,- "Pubd. \& Sept. 1783 by E. M. Diemar. Strand." Splendid impression printed in brownish ink. Condition perfect. Margin $1 / 8$ inch all around. VERY FINE AND RARE.

A companion piece to "A St. James Beauty."

\section{BARTOLOZZI, FRANCESCO}

5. A Str. James Beautr. Stipple Engraving.

Engraved after the painting by J. H. Benwell. Proof Before title, and with the address,- "Pubd. 8 Sept. 1783 by E. M. Diemar Strand." Very Fine impression printed in brownish ink. Condition perfect. Margin 1/8 inch all around. Very FINE ANd RARE.

Companion piece to "A St. Giles Beauty."

\section{BARTOLOZZI, FRANCESCO}

6. Mary Queex of Scots and Her Son. Engraving.

Engraved after the painting by F. Zuccheri. Proof beFore title. Fine impression in perfect condition. Original margins. 


\section{First Session, Tuesday Evening, A pril 10th}

\section{BARTOLOZZI, FRANCESCO}

7. Innocence Taught by Love and Friendente. Stipple Engraving.

Tuer, No. 72.

Engraved after the design of Cipriani. Printed in sanguine. Good impression.

The Flower Girl. Stipple Engraving.

Published in $\mathbf{1 7 8 5}$ by J. Walker. Fine impression, printed in sanguine.

Together, 2 pieces. Both framed.

\section{BARTOLOZZI, FRANCESCO}

8. Spring. Stipple Engraving.

Tuer, No. 166.

Engraved after the painting by F. Wheatley. Fine mipression, but cut to the engraved surface.

Framed.

\section{BARTOLOZZI, FRANCESCO}

9. Winter. Stipple Engraving.

Tuer, No. 169.

Engraved after the painting of F. Wheatley. Good impression with letters.

Framed.

\section{BARTOLOZZI, FRANCESCO}

10. The Dowager Queen of Edward IV. Parting with Duke оғ York. Stipple Engraving.

Tuer, No. 1261.

Engraved after the design by G. B. Cipriani. Proof before letters. Splendid impression with Margins. VERY FINE.

Framed.

\section{BARTOLOZZI, FRANCESCO}

11. Vexus Surrounded by Cupids. Stipple Engraving.

Tuer, No. 1608.

Engraved after the drawing by G. B. Cipriani. BeautiFUL PROOF BEFORE TITLE, printed in brownish ink. Condition very good. Mended tear in lower left corner. Margin 1/16 inch all around. Mounted down for framing. 
First Session, Tuesday Evening, April 10th

BARTOLOZZI, FRANCESCO

12. Mrs. Abington as Thalia. Stipple Engraving.

Tuer, No. $161 \%$.

Engraved after the painting by Richard Cosway. Proof BEFORE TITLE, printed in brownish ink. Fine IMPREssion. Condition Perfect. Margin $1 / 16$ inch all around.

\section{BARTOLOZZI, FRANCESCO}

13. Mrs. Abington as Thalia. Stipple Engraving.

Tuer, No. $161 \%$.

Engraved after the design by Richard Cosway. Proof BEFORE TITLE, printed in sanguine. Good IMPRESSION And in Perfect condition. Margin cut to plate-line.

\section{BARTOLOZZI, FRANCESCO}

14. The Daughters of Lady Diana Beauclerk. Engraving. Tuer, No. 1628.

Engraved after the drawing by Lady Diana Beauclerk. Fine impression, printed in brownish ink. Condition very good. One slight fold through middle. Cut just inside the plate-mark. Mounted down for framing.

\section{BARTOLOZZI, FRANCESCO}

15. Mrs. Crouch. Stipple Engraving.

Tuer, No. 1651.

Engraved after the painting by Romney. Proof before all letters. Beautiful mellow impression, in PerFECT CONDITION and with full margin.

\section{BARTOLOZZI, FRANCESCO}

16. Charles Burney. Stipple Engraving.

Tuer, No. 1748.

Engraved after the painting by Sir Joshua Reynolds. SPlendid impression with letters. Condition fair. Slightly rubbed and wrinkled in lower left corner of margin. Cut on the plate-mark. Rare. 
First Session, Tuesday Evening, A pril 10th

\section{BARTOLOZZI, FRANCESCO}

17. Lord Hawke, Lieut. Gov. of Greenwich Hospital. Stipple Engraving.

Not in Tuer.

Engraved after the painting by Coates. Splendid Impression. Proof before title, printed in brownish ink. IN IMMACULATE CONDITION WITH ORIGINAL MARgINS.

\section{BARTOLOZZI, FRANCESCO}

18. Ophelia. Stipple Engraving.

Not in Tuer.

Engraved after the painting by James Nixon. Proof before alL Letters. Fine impression, printed in brown. Full margins.

Framed.

\section{BARTOLOZZI, FRANCESCO}

19. "Veillez Amans si l'Amour Dort." Stipple Engraving. Engraved after the design of Angelica Kauffman. FInE impression, with letters. In perfect condition.

Le Coucher. Engraving.

Engraved by G. Kellaway after the painting by Carle Vanloo. Fine impression, with letters. Ix perfect Condition and with original margins.

Together, two pieces.

\section{BARTOLOZZI, FRANCESCO}

20. Orange Girl. Stipple engraving.

Engraved after Benwell. Late impression with letters.

In PERFECT CONDITION.

Jane Shore. Stipple engraving.

Fine impression with letters. Condition perfect. Margin 1 to $1 \frac{1}{2}$ inches all around.

Together, 2 pieces. 


\section{ÉTIENNE BAUDET}

French line-engraver, born at Vineuil about 1636. He was a pupil of Bourdon and Bloemart; also, a member of the Royal Academy of Paris, in which city he died in 1711 .

BAUDET, ÉTIENNE

21. Louise, Duchess of Portsmouth. Engraving.

Engraved after the painting by H. Gascar. Fair impression in fair condition. Somewhat stained. RARE. Framed.

\section{ISAAC BECKE'T}

English engraver, born in Kent, 1653. He was bred to the business of calico-printing, but becoming acquainted with the mezzotinter Lutterel, he learned from him the process, and became one of the earliest mezzotint engravers in England.

BECKET, ISAAC

22. Barbara, Duchess of Cleveland. Mezzotint.

Smith, No. 22.

Engraved after the painting by Sir Godfrey Kneller. SECond state, with the words,- “I. Smith ex." Good impression. Surface and condition fair. Margin 1/16 inch all around.

"Her (The Duchess of Cleveland) acquaintance with Charles commenced in Holland in 1659. She became his avowed mistress at the Restoration, and exercised a power, or rather a tyranny, over him greater than even her beauty would seem possible to obtain."-J. c. SMITH.

\section{BECKET, ISAAC}

23. Lady Playing the Violoncello. Mezzotint. Smith, No. 103.

SCratched LetTer proof before further inscription. Very fine impression. Surface and condition practically perfect. Thin places along the edge. Cut just outside the plate-mark.

Smith suggests that this may be a portrait of Miss Mary Davis.

From the collection of Queen Victoria of England. 


\section{HANS SEBALD BEHAM}

"If Barthel was the more talented artist, Hans Sebald Beham (1500-1550), who was probably of a stronger nature or constitution, and able to give more assiduous practice to his craft, attained to a greater virtuosity in engraving, and left a far more prolific work. On his earlier prints he used a monogram composed of the letters H. S. P., while later, from about 1531, that is, about the time of his settlement in Frankfort, he changed the signature to H. S. B."-A. м. HIND.

\section{BEHAM, HANS SEBALD}

24. Death and the Womax. Engraving.

Bartsch, No. 149.

Signed on the plate,_- $H S B$." Engraved after his own design in 1541. Fair impression and in good condition except for a mended crease across the bottom. The inscription on the plate reads,- "Omnem in homine venustatem mors abolet."

\section{ABRAHAM BLOO'TELING}

Born at Amsterdam, 1634; died, after 1685. Draughtsman, line-engraver and mezzotinter. Pupil of Cornelius van Dalen.

\section{BLOOTELING, ABRAHAM}

25. Anne Killigrew. Mezzotint.

Not in Smith.

Engraved after the painting by Anne Killigrew. VEry Fine impression with letters. Surface very good. ConDition PERfect. Margin $1 / 4$ inch all around. RARE.

Anne Killigrew, the daughter of Dr. Henry Killigrew, was eminent in poetry and painting. She died in 1685 in her 25th year and was buried in the Parry Chapel.

\section{BLOOTELING, ABRAHAM}

26. Catherine of Exgland. Mezzotint.

Engraved after the painting by Sir Peter Lely. SpLexDID IMPREssion, with inscription. Surface and condition perfect. Margin 1/4 inch all around. 


\section{First Session, Tuesday Evening, A pril 10th}

\section{BLOOTELING, ABRAHAM}

27. Louise, Duchess of Portsmouth. Mezzotint.

Smith, Letter N.

Engraved after the painting by Sir Peter Lely. SEcond state, with inscription. Fine impression. Surface and condition good. A few slight rubs and thin spots. Cut on the plate-line.

\section{BLOOTELING, ABRAHAM}

28. Mary, Princess of Orange. Mezzotint.

Engraved by an unknown artist, perhaps by Blooteling. Proof before letters. Splendid impression. Surface and condition good. Several thin places. Cut outside plate-mark.

Charles II as a Child. Mezzotint.

Smith, Letter i.

Engraved after the painting by Sir Anthony Van Dyck. Second state with inscription. Fine impression. Surface slightly wrinkled. Condition perfect. Margin $3 / 4$ inch all around.

Together, 2 pieces.

\section{BLOOTELING, ABRAHAM}

29. Count Huyghens. Engraving.

Engraved after the painting by $\mathrm{N}$. Visscher. Unique state. Splendid impression, in practically perfect condition. Margin on one side reinforced. Margin $1 / 8$ to $1 / 4$ inch all around.

\section{BLOOTELING, ABRAHAM}

30. Tête de L'Enfant. Engraving.

Dutuit, No. 98.

Le Même. Vue de Profil.

Dutuit, No. 99.

After paintings by Rubens.

Together, 2 pieces. 


\section{First Session, Tuesday Evening, A pril 10th}

\section{JEAN JACQUES DE BOISSIEU}

French painter, more celebrated as an engraver. Born at Iyons, 1736; where he died in 1810 .

\section{BOISSIEU, JEAN JACQUES DE}

31. Paysage. Etching.

Signed on the plate,-“D. B. 1800." V'ErY Fine impresSion in PERFECT Condition. Printed on Japan paper. Ample margins. Mounted down for framing.

\section{ALEXANDER BROWNE}

"A considerable number of mezzotints of the last three decades of the 17th Century bear the names of Richard Tompson and Alexander Browne, but as they are never accompanied by anything but the word "exc." it is doubtful whether they were ever more than the printers and publishers." -A. M. HIND.

\section{BROWNE, ALEXANDER}

32. Frances, Countess of Portland. Mezzotint.

Smith, No. 29.

Published by A. Browne. Engraved after the painting by Sir Anthony Van Dyck. Only state. Fine Rich impression. Surface and condition very good. Margin $1 / 8$ inch all around.

\section{LUIGI CALAMATTA}

Calamatta (1802-1869), an Italian engraver, went to Paris and had an immediate success by securing the patronage of Ingres. In 1837 he became professor at the "Academy of Fine Arts" at Brussels. Among his pupils were,-Flameng, Desvachez, Biot, and Charles Blanc.

CALAMATTA, LUIGI

33. Francesca da Rimini. Engraving.

Beraldi, No. 4.

Engraved after the painting by Ary Scheffer. STIPpled LETTER PROOF BEFORE TITLE, ON INDIA PAPER, with original margins. 


\section{DAVID YOUNG CAMERON}

Celebrated contemporary Scotch painter and engraver. Born at Glasgow in 1765 .

"In examining Cameron's etchings it is not easy to designate his forte . . Cameron (though we hope his best work is still to be done) already shows himself equally at home when delineating pure landscape, views of buildings and shipping, interiors, or portraits."-FrEDERICK KEPPEL.

\section{CAMERON, DAVID YOUNG}

34. The Abbazia, Venice. Etching.

Rinder, No. 306.

Signed Artist's proof on soft Japan paper. Third state, with additional ink on the steps. Fine impression printed with brownish ink. IN PERFECT CONDITION. About 30 impressions. ONe OF THE ARTIST's MASTERPIECES. RARE.

\section{CAMERON, DAVID YOUNG}

35. Rose Window, St. Mark's. Etching.

Rinder, No. $30 \%$.

Signed ARTIST's PRoof on old paper water-marked with a scallop shell. Fourth state. Beautiful impression, in perfect condition and with full margins.

Extremely fine and rare. One of the artist's masTER PIEC ES.

\section{[See Reproduction $]$}

\section{MANUEL SALVADOR CARMONA}

Engraver and designer; born at Madrid in 1730; became a pupil of Dupuis in Paris. He died at Madrid in 1807.

\section{CARMONA, MANUEL SALVADOR}

36. Le Fils de Rubens. Engraving.

Dutuit, No. 54.

Engraved after the painting by Rubens. First state, before all letters. Splendid impression in perfect conDITION. RARE. 


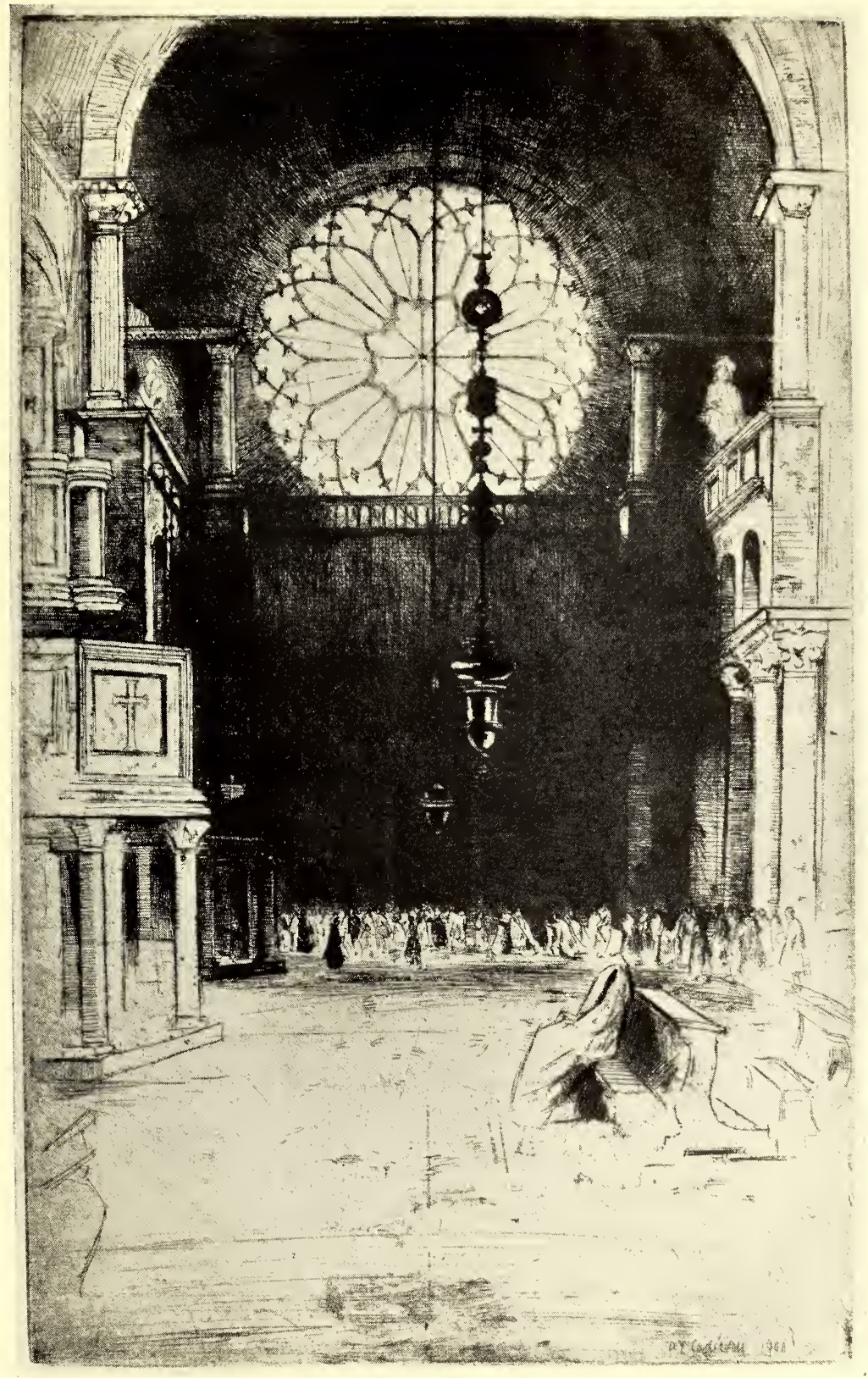

\section{DAVID YOUNG CAMERON. ETCHING}

Rose Window, St. Mark's

[No. 35] 


\section{THOMAS CHEESMAN}

Born in 1760, and was a pupil of Bartolozzi. He worked in both stipple and mezzotint.

\section{CHEESMAN, THOMAS}

37. The Lady's Last Stake, or Virtue in Danger. Stipple Engraving.

Dobson, page 317 .

Engraved after the painting by William Hogarth. Proof BEFORE ALL LETTERS. VERY FINE EARLY IMPRESSION IN Perfect condition. Plate-line intact. Several slight mended tears in the margin. VERY FINE AND RARE.

Mrs. Thrale (or Mrs. Piozzi), who claimed to be the original of the picture, wrote the following account of the painting,-

"The next time we went to Leicester Fields, Mr. Hogarth was painting, and bid me sit to him: 'And look here now,' said he, 'I am doing this for you. You are not fourteen years old yet I think, but you will be twenty-four, and this portrait will then be like you. 'Tis the Lady's Last Stake; see how she hesitates between her money and her honor. Take you care; I see an ardor for play in your eyes and in your heart; don't indulge it. I shall give you this picture as a warning, because I love you now, you are so good a girl." "'

\section{PIERRE CHARLES COQUERE'T}

French engraver in aquatint; born at Paris in 1761. He studied under Janinet and produced a large number of very excellent engravings.

\section{COQUERET, PIERRE CHARLES}

38. The Horse Dealer. Aquatint.

Engraved after the painting by C. Vernet. Proof BEfore title. Splendin impression. Surface very good. Condition fair. Several tears in the margin. $\mathbf{R}_{\mathrm{AR}}$.

\section{SAMUEL COUSINS}

Born in Exeter, 1801; died in London, May 7, 1887. Pupil of S. W. Reynolds.

"Un des meilleurs graveurs anglais de ce siècle."- HENRI BERALDI.

\section{COUSINS, SAMUEL}

39. Prince Metternich. Mezzotint.

Whitman, No. 109.

Engraved after the painting by Sir 'Thomas Lawrence. 


\section{First Session. Tuesday Evening, A pril 10th}

[No. 39-Continued]

First state. Very fine impression. Surface and condition good. Original margins.

From the collection of Sir Thomas Lawrence.

COUSINS, SAMUEL

40. "Turn Again Whittington." Mezzotint.

Whitman, No. 234.

Engraved after the painting by James Sant. ONLY state. Fair impression. Surface good. Condition fair. Margin $1 / 8$ to $1 / 2$ inch all around. Mounted on linen for framing.

\section{I. DANFORTH}

English engraver of the 19th century.

\section{DANFORTH, M. I.}

41. Uncle Toвy. Engraving.

Engraved after the painting by C. R. Leslie. Scratched letter proof before title. Splendid impression in PERFECT CONDITION AND WITH ORIGINAL MARGINS.

\section{LUCIEN DAUTREY}

Contemporary French reproductive etcher. Pupil of Courtry.

\section{DAUTREY, LUCIEN}

42. The Gleaner. Etching.

Etched after the painting by Jules Breton. EARLY Trial proof on Japan Paper signed in pencil by both painter and engraver. Fine impression. Good condition. A small tear to the right. 


\section{First Session, Tuesday Evening, A pril 10th}

\section{HENRY DAWE}

Engraver and subject painter. Born near London in 1790; died, 1848. Studied with his father, Philip Dawe, and in the Royal Academy. He assisted Turner in the "Liber Studiorum." Became a member of the "Society of British Artists" in 1830.

\section{DAWE, HENRY}

43. Mrs. Siddons as the Tragic Muse. Mezzotint.

Not in Smith.

Engraved after the painting by Sir Joshua Reynolds. Proof before all letters. Superb impression. Surface and condition perfect. Margin 1 to $1 \frac{1}{2}$ inches all around. VERY FINE AND RARE.

\section{JOHN DEAN}

Mezzotint engraver, a pupil of Valetine Green. He scraped several plates of portraits and other subjects in a very respectable style. Died in London in 1798 .

DEAN, JOHN

44. Mrs. Martrr. Mezzotint.

Smith, No. 18.

Engraved after the painting by M. Brown. First state, scratched letter proof. Superb impression. Surface very fine. Condition good. Corners of margins slightly mended. Margin $1 / 4$ inch all around. VERY FINE AND RARE.

"Maiden name Thornton; appeared first in public as a singer at Vauxhall and was afterwards engaged at Covent Garden. She was a farorite in Rosetta and other characters in English opera."-J. c. SMITH.

\section{FRANCIS DELARAM}

Born, 1590; died, 1627. Contemporary with Elstracke and Van de Passe. Engraved various plates in the neat and formal style which was prevalent at that time.

\section{DELARAM, FRANCIS}

45. King James of England. Engraving.

Fine impression, with letters. Condition perfect. Cut just inside the plate-mark all around. VERY FINE AND OF THE GREATEST RARITY. 


\title{
First Session, Tuesday Evening, A pril 10th
}

\section{DELARAM, FRANCIS}

46. Henry VIII. Engraving.

Signed on the plate,-“Francisco Delaram Scul." First state, before the address was changed to "Are to be sould by William Peake." VEry Fine impression in Perfect Condition. Margin $3 / 4$ inch all around. VERY FINE AND RARE.

From the collections of St. John Dent and E. W. Martin.

\section{DELARAM, FRANCIS}

4\%. Capt. Arthur Severus Nonsuch O'Toole. Engraving.

VERY FINE IMPREssion with inscription. Condition very good; a few small mended tears. Margins 1/16 inch all around. OF THE GREATEST RARITY.

O'Toole was a soldier of fortune who served against the Irish rebels, and in various parts of Europe. He was the subject of an ironical Panegyric by Taylor, the water-poet, who classed him with Amadis de Gaul, Don Quixote, etc.

\section{DELARAM, FRANCIS}

48. Queen Mary of England. Engraving.

Signed on the plate,-“Fran. Delaram Sculp." First state. Splendid impression in perfect Condtion. Cut on the plate-line. VERY FINE AND RARE.

From the Buckingham, Dent and Walker Collections.

\section{THOMAS DE LEEUW (OR DE LEU)}

\begin{abstract}
"Native of Flanders, was in France from 1560 to 1612. Pupil of Jean Rabel, afterwards of Antoine Caron, whose daughter he married. Engraved at first after Cornelis Cort, Sadeler, and Wierix, in a dry-point manner, but devoted himself afterwards to portraiture, in which he became one of the most distinguished artists of his time."-BRYAN's DICTIONARY OF ENGRAVERS AND PAINTERS.
\end{abstract}

\section{DE LEEUW (OR DE LEU), THOMAS}

49. Montaigne. Copperplate Engraving.

Fine impression, signed below the inscription,-“Thomas de Leu, fecit." Condition perfect. 
First Session, Tuesday Evening, April 10th

DE LEEUW (OR DE LEU), THOMAS

50. Francis II. King of France. Engraving.

Very fine impression. With inscription. In perfect CONDITION.

\section{DE LEEUW (OR DE LEU), THOMAS}

51. Mary Stuart. Engraving.

Signed on the plate,-“Tho. de leu F. et ex." Fine ImPression. A few thin places, otherwise perfect condition. From the collection of Pierre Mariette, 1664.

\section{WILLIAM DICKINSON}

Born in London, 1746; died in Paris, 1823.

"Associated with Thomas Watson in print selling and of close affinity with his style and technique. . . . With a pictorial sense that was exquisite and a touch full of vivacity and vigor, Dickinson, of course, became one of Sir Joshua's trusted interpreters. His prints after the master are among those most valued by collectors."-м. c. salaman,-Old English Mezzotints.

\section{DICKINSON, WILLIAM}

52. Mrs. Gwynne and Mrs. Bunbury. Mezzotint. Smith, No. 34 .

Engraved after the painting by D. Gardner. Finst state, before the names of the personages were erased. Beautiful impression. Perfect surface and condition. Margin $1 / 8$ inch all around. Exceedingly fine. From the W. Drugulin Collection.

\section{DICKINSON, WILLIAM}

53. Mrs. Hartley in the Character of Elfrida. Mezzotint. Smith, No. $3 \%$.

Engraved after the painting by J. Nixon. SEcond state, with inscription. Fine impression. Surface good. Condition perfect. Cut on the plate-line.

"Mrs. Hartley first appeared at Bath about 1771, and became very popular as a tragic actress, more probably from her beauty than her talents; left the stage 1780 . The play Elfrida was specially written for her by Mason, and she was most successful in it."-J. c. sMiTH. 


\section{First Session, Tuesday Evening, A pril 10th}

\section{DICKINSON, WILLIAM}

54. The Rev. Thomas Warton. Mezzotint.

Not in Smith.

Published in 1786 by W. Dickinson. Probably engraved by Hodges. Open letter proof. Cut inside plate-line. Good impression, surface little rubbed.

A portrait of the celebrated professor of poetry at Cambridge.

\section{JOHN DIXON}

Mezzotint engraver; born in Dublin about 1740; died in London, 1780. He studied under West in Dublin, and in 1766 became a member of the "Incorporated Society of Artists."

\section{DIXON, JOHN}

55. Garrick as Richard III. Mezzotint.

Smith, No. 15.

Engraved after the painting by N. Dance. First state, scratched letter proof. Splendid impression. Surface and condition perfect. Margin $1 / 4$ inch all around. VERY FINE AND RARE.

From the Brentano collection.

"Garrick, born in 1716, pupil of Samuel Johnson; at first intended for the bar, but adopted the stage in 1741; became distinguished as actor, manager, author, and was one of the leading minds of the time; died, Jan. 1779."-J. c. sMirh.

\section{ASHER B. DURAND}

American Line-Engraver. Born at Jefferson Village (So. Orange), New Jersey, August 21, 1796; died in 1886.

DURAND, ASHER B.

56. William Cullen Bryant. Engraving.

Grolier Catalogue, No. 15.

Engraved after the painting by Asher B. Durand. First STATE, PROOF BEFORE ALL LETTERS ON INDIA PAPER. Splendid impression in perfect condition and with original margins.

The final work on the plate was done by Durand himself. The head was etched on the plate by Charles Burt, filled by Schoff, and finished by Jones to the first state. 
DURAND, ASHER B.

5\%. Musidora. Engraving.

Grolier Catalogue, No. 236.

Engraved after the artist's own design. Splendid im-

pression. In perfect condition. Presentation copy.

Framed.

DURAND, ASHER B.

58. Ariadne. Engraving.

Grolier Catalogue, No. $23 \%$.

Engraved after the painting by Vanderlyn. Proof BEFORE TITLE ON INDia PAPER, With FULL MARgins.

\section{ALBRECH'T DÜRER}

Celebrated German painter and engraver. Born of Hungarian descent at Nüremberg in 1471, died there in 1528. He studied with Michael Wolgemut at Nüremberg and made several journeys to Italy. Like so many of the great artists of the period, he was a man of wide attainments. A scientist, writer, and mathematician as well as artist, he counted among his friends Erasmus, Luther, Melanchthon, Bellini and Raphael. His influence dominated the engraving of all the North Countries. His copper-engravings, woodcuts, and even his etchings in their way have never been surpassed. "Dürer did not possess the modern sense of limitation. . . His imagination was deeply suggestive, straightforward, and marvelously fertile in invention; but he interpreted the imaginative world in terms of daily and often homely life; he knew beauty only as German Beauty, and life and its material surroundings only as German life and German civilization. . . But the grotesqueness disappears as the eye becomes acquainted with the unfamiliar, and the mind is occupied with the emotion, the intellectual idea, and imaginative truth expressed in these sometimes ugly modes, for they are of that rare value which wins forgiveness for far greater defects of formal beauty than are apparent in Diurer's work."GEORGE EDWARD WOODBERRY.

\section{DÜRER, ALBRECHT}

59. Christ on the Mount of Olives. Etching.

Bartsch, No. 19.

Signed on the plate with the monogram,-“ $A D$ 1515." Fine impression. Margin cut inside the plate-mark.

From the Alferoff collection and another unknown to Fagan.

"The etchings fall into a class by themselves, remarkable in Dürer's work not only for the technical method of production but also for the spirit in which they are conceived. Among the earliest etchings known to us, for they were made in the five years following 1513, the first date that appears on an etched plate, they are also among the finest. If we judge them from the point of view of the cookery 
[No. 59-Continued]

of etching they are uncouth, as is to be expected when we remember that they were done on iron plates with an etching ground that in all probability consisted of boiled linseed oil and red lead. Moreover, in addition to the fact that there is no internal evidence that Dürer knew anything about stopping-out or rebiting, the action of the mordant on the iron gave the lines a peculiar raw, flat quality wholly unlike that produced when copper is used. Now if these facts are borne in mind it will be found that the etchings are finer works of art than many of the famous and generally admired engravings. . . . The wonderful Agony with its dramatically symbolic tree blasted and tortured in the more than earthly storm-a tree only to be approached in one of Blake's woodcuts. . . ."-w. M. IVINs, Jr.

\section{DÜRER, ALBRECHT}

60. Virgin with Long Hair. Engraving.

Bartsch, No. 30.

Signed on the plate with the monogram,- “A D." Engraved after his own design in 1508. Good impression. Several thin places. Cut on the plate-mark.

From an unidentified collection. Duplicate from the Berlin Museum.

"For in the same way as they (the ancients) applied the most beautiful of a man to their idol, Apollo, thus we will take the same measurement for Christ, the Lord, who is the most beautiful of all the world. And as they have used Venus as the most beautiful woman, thus will we chastely devote the same graceful figure to the most pure Virgin, the Mother of God."-ALBrecht Düren,-Notes for an Introduction to his Book, "On the Proportions of the Human Body."

\section{DÜRER, ALBRECHT}

61. Virgin with Crown and Sceptre. Engraving. Bartsch, No. 32.

Signed on the plate with the monogram,- “A. D." Engraved after his own design in 1516. Fair impression with plate-line intact. IN PERfECT Condition.

\section{DÜRER, ALBRECHT}

62. Virgin Crowned by One Angel. Engraving. Bartsch, No. 3\%.

Signed on the plate with the monogram,- “A. D." Engraved after his own design in 1520. Fair impression, in PERFECT CONDItIon. On paper with the watermark of the little jug. Margin $1 / 16$ inch top and sides, 3/16 inch on the bottom.

From the Ruhl and Theodore Roussell collections. 


\section{First Session, Tuesday Evening, A pril 10th}

DÜRER, ALBRECHT

63. St. George Standing. Engraving.

Bartsch, No. 53.

Signed on the plate with the monogram,-“A. D." Engraved after his own design. Fine impression, with 1/16 inch margin. One very slight thin place, otherwise in fine condition. $\mathrm{R}_{\mathrm{ARE}}$.

\section{DÜRER, ALBRECHT}

64. St. Jerome in His Cell. Engraving.

Bartsch, No, 60.

Signed on the plate with the monogram,- “A. D." Engraved after his own design in 1514. BEAUTIFUL IMpression in perfect condition. Trimmed outside the plate-mark. OF THE GREATEST RARITY.

From the T. E. Crawhall, and Julian Marshall Collections.

"It is absolutely necessary to have this print in delicate, thoroughly transparent impressions. One of the greatest charms is the reflected light which fills the room and penetrates even the shadow under the wall. This effect, which is so thoroughly in accord with the subject, . . is lost in heavy or dull impressions."-s. R. KOEHLER,-Grolier Catalogue.

\section{[See Reproduction]}

\section{DÜRER, ALBRECHT}

65. Effects of Jealousy. Engraving.

Bartsch, No. 73.

Signed on the plate with the monogram,-“ $A$. D." Very FINE CLEAR IMPRESSION IN UNUSUALLY PERFECT CONDItion. Margin $1 / 32$ to $1 / 16$ inches all around. VERY FINE AND RARE.

From the Archinto, Julian Marshall and Alfred Morrison collections.

\section{DÜRER, ALBRECHT}

66. The Dream. Engraving.

Bartsch, No. 76 .

Signed on the plate with the monogram,- “ $A$. D." Engraved after his own design. Brilliant impression. Several thin places. Margin cut to plate-mark. From the collection of the Duke of Buccleugh. 


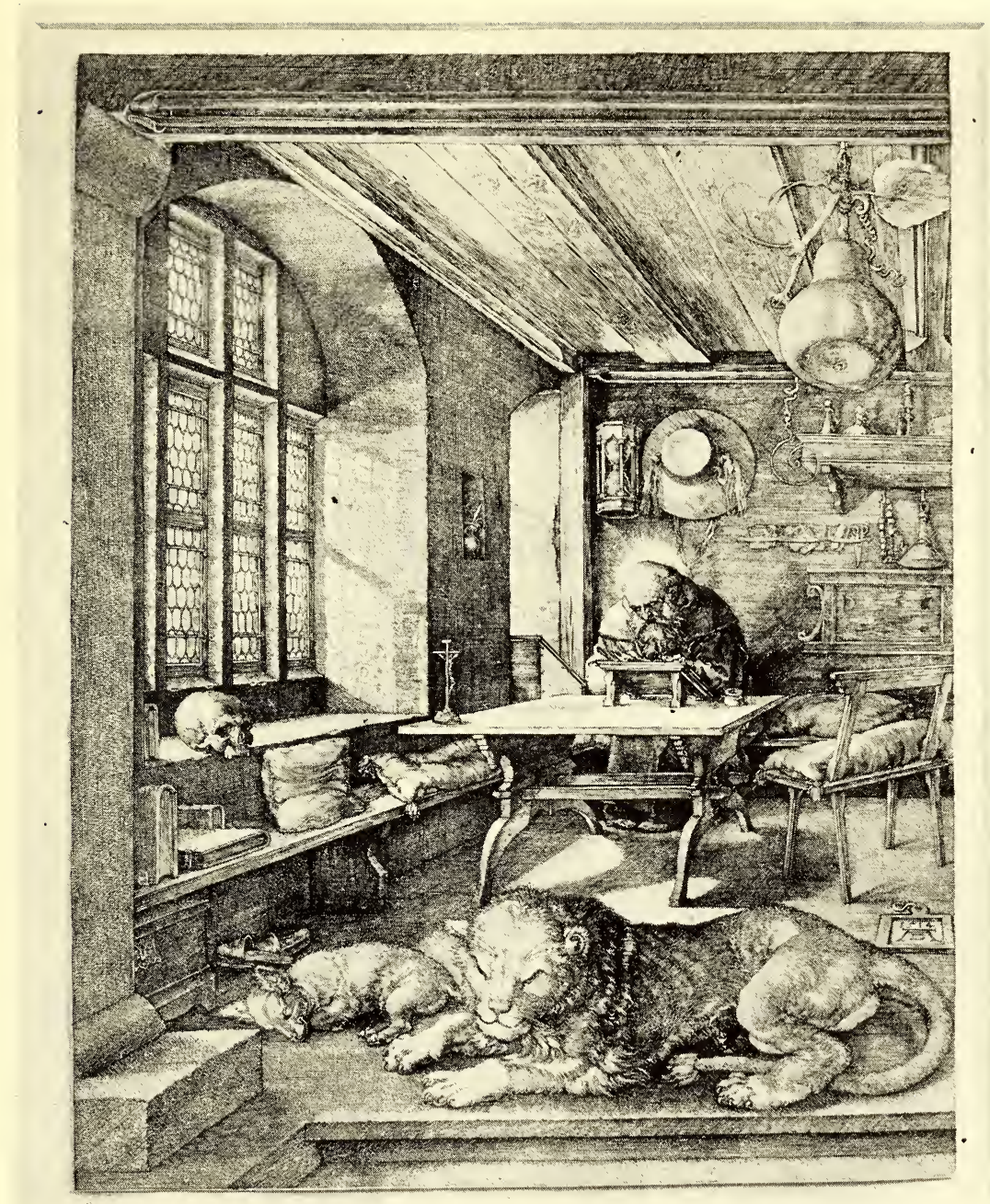

\section{ALBRECH'T DÜRER, ENGRAVING}

St. Jerone in His Celi

[No. 64] 


\section{DÜRER, ALBRECHT}

6\%. The Standard Bearer. Engraving.

Bartsch, No. $8 \%$.

Signed on the plate with the monogram,-“ $A$. D." Engraved after his own design. Fine impression and in PERFECT CONDITION, with $1 / 16$ inch margin all around.

\section{DÜRER, ALBRECHT}

68. 'The Little Horse. Engraving.

Bartsch, No. 96.

Signed on the plate with the monogram,- " $A$. D." Engraved after his own design in 1505. Extraordinarily BRILLIANT IMPRESSION on paper with the watermark of "The Bull's Head," Haussman No. 19. Margin 1/16 inch all around. A few thin places, otherwise in perfect condition.

From the collection of the Duke of Buccleugh.

\section{DÜRER, ALBRECHT}

69. KNight, Death and the Devil. Engraving.

Bartsch, No. 98.

Signed on the plate with the monogram,-“A. D." Engraved after his own design in 1513. Brilliant IMPRESSION IN PERFECT CONDITION. Trimmed outside the platemark. Extremely fine and of The GREATEs? RARITY.

"Much has been written about the meaning of this engraving, which Dürer himself calls Der Reuter. The interpretation of the Christian Knight is the oldest, simplest, and best. Passing resolutely through the terrors of this mortal life, turning his back on temptation and undismayed by the prospect of temporal death, he rides straight on along the road which will eventually leave the dark valley and lead up to the bright city on the hill. This notion of the Christian Knight, to which Erasmus gave the greatest vogue by the publication of his Enchiridion Militis Christiania, had been current long before in the mystical literature and popular theology of the fifteenth century. It had already inspired some rude woodcut illustrations, and Dürer was not so much expressing an original thought of his own as giving the first adequate artistic form to a conception universally familiar in his generation."-CAMPBELL nODGSON.

[See Frontispiece for Reproduction] 


\section{First Session, Tuesday Evening, A pril 10th}

\section{DÜRER, ALBRECHT}

70. Cont-of Arms with a Cock. Engraving.

Bartsch, No. 100.

Signed on the plate with the monogram,-“A. D." Engraved after his own design in 1512. Splexid impresSion in PERFECT Condition. Cut on the plate line. Inner margin lines added in ink. Extremely fine AND RARE.

From the Brentano and Kennedy collections.

"He drew splendid coats-of-arms, including the finest the Renaissance produced in the way of heraldry."-kNACkFuss.

\section{DÜRER, ALBRECHT}

71. Cont-of Arms with a Skull. Engraving.

Bartsch, No. 101.

Signed on the plate with the monogram,-“A. D." Engraved after his own design in 1503. Extrenely BRILLIANT IMPRESSION IN PERFECT CONDITION. Cut outside the plate-line. Extremejy fine and rare.

From the collection of the Duke of Buccleugh.

"Called also the Coat of Arms of Death and The Dying Bride. A much-discussed print, which, however difficult it may be today to follow the wandering fancy of the artist it would seem safe to connect in a general way with the idea of the 'Dance of Death,' although the 'wild man' is evidently not a personification of Death, but a Satyr, as his right leg, visible to the left, clearly shows."Catalogue.

\section{DÜRER, ALBRECHT}

72. The Four Riders. Woodcut.

Bartsch, No. 64.

Signed on the plate with the monogram,-“A. D." Impression without the text on the back, probably after the regular edition. Brilliant impression on paper water-marked with "The Little Jug." PERFECT CondTIos. Margin 3/16 inch all around. One of the most famous of the illustrations to the Apocalypse.

From the collection of A. Artaria. 


\title{
DÜRER, ALBRECHT
}

73. The Martyrdom of St. Catharine Woodcut. Bartsch, No. 120.

Signed on the plate with the monogram,-_ $A$. D." Fine clear proof, but somewhat battered, skilfully mended. Cut on the plate-mark.

\section{DÜRER, ALBRECHT}

74. The Emperor Maximilian. Woodcut.

Bartsch, No. 153.

Signed on the block with the monogram,-“ “A. D." Fair impression. Cut on plate-mark. Laid down to mend a cut on the left.

\section{CORNELIS DUSAR'T}

\begin{abstract}
Born at Haerlem, in 1660; died there in 1704 .
"He was a pupil of Adriaan Van Ostade, whose style he imitated with considerable success. His works, like those of Ostade, represent Dutch peasants regaling and merry-making. Although not equal to his master in the richness of his tones and the harmony of his effects, his coloring is clear and agreeable, his compositions ingenious, and his touch very spirited." -BRYAN.
\end{abstract}

\section{DUSART, CORNELIS}

75. Le Barbier. Mezzotint.

Bartsch, No. 18.

Engraved after the artist's own design. Fine impression in very good condition. Extremely rare.

\section{DUSART, CORNELIS}

76. Le Tabac Présenté. Mezzotint.

Bartsch, No. 19.

Engraved after the artist's own design. Superb impression. Surface and condition perfect. Margin 1/8 inch all around. Very fine and extremely rare. 


\section{DUSART, CORNELIS}

7\%. LA Loterie de Grotteniroeck. Mezzotint.

Bartsch, No. 40.

Engraved after the artist's own design. Finst state, proof beFore ALL LetTers. SpleNdid IMPRESSION IN perfect condtion. Extremely rare.

\section{DUSART, CORNELIS}

78. Les Sept. Mezzotint.

Bartsch, No. 41.

Engraved after the artist's own design. Splendid ImPRESSION IN PERFECT CONDITION.

\section{DUSART, CORNELIS}

79. Victoria Publica. Mezzotint.

Not in Bartsch.

Engraved after the artist's own design. Fine impresSION IN PERFECT CONDITION.

A scene representing a public celebration, perhaps the same which Dusart shows in Bartsch No. 32-37, the festival on the occasion of the capture of Namur by William III. of Orange, King of England.

\section{RICHARD EARLOM}

Born in Somersetshire, 1743; died in London, 1822. He was at first a pupil of Cipriani, but later devoted himself to mezzotint engraving. He executed few works in stipple, but they are of a quality which entitled him to rank as one of the greatest engravers in that manner.

\section{EARLOM, RICHARD}

80. Jupiter and Calisto. Mezzotint.

Wessely, No. 86.

Engraved after the painting by Sir Anthony Van Dyck.

Second state. Scratched letter proof, with coat of arms. Surface and condition good. Right corner of margin mended. 


\section{EARLOM，RICHARD}

81. The Lioness and the Wild Boar. Mezzotint. Wessely, No. $13 \%$.

Engraved after the painting by F. Snyders. First state. Scratched letter proof. Brilliant impression. Surface and condition very good. Margin $3 / 4$ inch all around.

\section{GÉRARD EDELINCK}

Born at Antwerp, 1640; died at Paris, 1707. Pupil of C. Galle and later of Poilly at Paris.

"Others may have surpassed him in particular things, but; according to the Italian teacher, he remains, by common consent, the Prince of engrazing. Another critic calls him King."-chardes sumer.

\section{EDELINCK, GÉRARD}

82. Јонn Drydex. Engraving.

Robert-Dumesnil, No. $18 \%$.

Engraved after the painting by Sir Godfrey Kneller. Second state, with coat of arms. Grood IMPREssion in PERfECt Condition. Margin 1/16 inch all around.

\section{REGINALD ELSTRACKE}

Flourished in England about 1620.

"He worked chiefly for the booksellers, and his plates are almost entirely confined to portraits. He also engraved the title-page and several portraits for Holland's 'Baziliologia.'"-BRYAN.

\section{ELSTRACKE, REGINALD}

83. Sir Julius Caesar. Engraving.

Signed on the plate,-“R. Elstracke sculpsit." Finst state, before the address, probably unique. Splendin impression in PERFECT CONDITION. Margin $1 / 4$ inch all around. Extremely fine AND RARE. 


\section{First Session, Tuesday Evening, A pril 10th}

ELSTRACKE, REGINALD

84. Anne Boleyx. Engraving.

Signed on the plate,-“R. Elstrack sculpsit." Splendid IMPRESSION, IN PERFECT CONDITION. Margin $1 / 4$ inch all around. VERY FINE AND RARE.

\section{ELSTRACKE, REGINALD}

85. Thomas Howard, Earl of Suffolk. Engraving.

Signed on the plate,-“R. Elstracle Sculp." Sprendid impression, in perfect Condition. Margin $1 / 2$ to 1 inch all around. VERY FINE AND RARE.

From the E. W. Martin collection.

\section{ELSTRACKE, REGINALD}

86. John Oldenbarnerelt. Engraving.

Signed on the plate,-“ $R$. $E$. scul." Stperb mpression in PERFECT Condition. Margin $1 / 4$ inch all around. VERY FINE AND RARE.

\section{ELSTRACKE, REGINALD}

8\%. Sir Philip Sidney. Engraving.

Signed on the plate,-“R. Elstracke." Good impression, in good condition. One corner slightly mended. Cut on the plate-line.

From the F. Walker Collection.

\section{ELSTRACKE, REGINALD}

88. Mary Queen of Scots. Engraving. Signed on the plate,-“'R. Elstracke sculpsit." Good impression, in good condition. Cut on the plate-mark and remargined. $\mathrm{R}_{\mathrm{ARE}}$.

From the E. W. Martin and Joseph Crawhall collections.

\section{ELSTRACKE, REGINALD}

89. Sigismund III. of Poland. Engraving.

Signed on the plate,_- "R. E. sculp." Splexdid impression, in perfect condition. Cut on the plate-line. 


\section{GEORGE H. EVERY}

Contemporary English mezzotint engraver of the Cousins School.

EVERY, GEORGE $\mathrm{H}$.

90. For the Squire. Mezzotint.

Engraved after the painting by Sir John Millais. ArTIST'S PROOF ON INDIA PAPER, signed by both artists. Framed.

\section{EVERY, GEORGE H.}

91. Lilac. Mezzotint.

Engraved after the painting by Sir John Millais. ArTIST'S PROOF ON INDIA PAPER, signed by both artists. Framed.

\section{JOHN FABER, JR.}

Mezzotint engraver, was born in Holland in 1684; died at London, 1756. He greatly surpassed his father as a mezzotinter and was esteemed the ablest engraver of his time after John Smith.

FABER, JOHN, Jr.

92. Charles I. Mezzotint.

Smith, No. 74.

Second state, with the address of John Bowles. Fine impression. Surface and condition good. Cut on the plate-line.

Similar to Faithorne's mezzotint of the same subject.

FABER, JOHN, Jr.

93. William Congreve. Mezzotint.

Smith, No. 208.

Engraved after the painting by Sir Godfrey Kneller. Fine impression, with letters. Condition and surface very good. Margin $1 / 2$ inch all around.

This was plate number 40 of the Kitcat Club series.

"The Kitcat Club was founded not far from the year 1700 by Jacob Tonson, a bookseller and publisher who had the faculty of forming friendships with his many distinguished clients. The club began as an assembly of wits and authors who held their meetings in a small house in Shire Lane, but before long, noblemen of high descent and statesmen of far-reaching influence sought admission to such an extent that the Kitcat Club 'generally mentioned as a set of wits,' became-to quote the words of Horace Walpole-'in reality the patriots that saved Britain." "-c. s. HELLMAN. 
FABER, JOHN, Jr.

94. Alexander Pope. Mezzotint.

Smith, No. 293.

Engraved after the painting by Sir Godfrey Kneller.

First state, before the retouch and change of publisher.

Fine impression. Condition perfect. Surface good.

Cut just outside of plate-mark.

FABER, JOHN, Jr.

95. Alexander Pope. Mezzotint.

Smith, No. 294.

Engraved after the painting by C. Vanloo. Second state, with inscription. Fine impression. Surface and condition very good. Margin of one inch all round.

FABER, JOHN, Jr.

96. Cave Underhill in the Character of Obadiah. Mezzotint.

Smith, No. $35 \%$.

Engraved after the painting by R. Bing. Only state. Good impression. Surface fair. Condition perfect. Cut on plate-line and remargined. VERY RARE.

Probably Faber's first print.

Underhill's acting is alluded to by Cibber in Chap. V. of his Life. "The Tatler" for May 31, 1\%09, also calls attention to him as having been "a comic for three generations."

\section{ÉTIENNE FICQUET}

French engraver. Born at Paris in 1719; died there in 1794. He was instructed by Schmidt and Le Bas. Acquired great reputation by a set of small portraits which he engraved of distinguished literary characters of France. One of his best plates is a portrait of Mme. de Maintenon after Mignard.

FICQUET, ÉTIENNE

97. Françoise d’Aubigne, Marquise de Mantexon. Engraving.

Engraved after the painting by Pierre Miguard. VERY Fine impression, in Perfect condition. Margin 11/2 to 2 inches all around. 


\section{JOHN FINLAYSON}

Mezzotint engraver. Born about the year 1730, and worked in London. In 1773 he received a premium from the "Society of Arts" and about three years later he died.

\section{FINLAYSON, JOHN}

98. William Drummond. Mezzotint.

Smith, No. 5.

Engraved after the painting by Cornelis Jansen. First state, before any inscription. Superb impression. Surface very good. Condition perfect. Margin $1 / 8$ inch all around. VERY FINE AND RARE.

The poet William Drummond of Hawthornden was born in 1585 and died in 1649. Drayton and Ben Jonson are said to have been his friends.

\section{[See Reproduction]}

\section{FINLAYSON, JOHN}

99. Maria, Duchess of Gloccester. Mezzotint.

Smith, No. 9.

Engraved after the painting by Sir Joshua Reynolds. First state, before the name and the coat of arms. Splendid impression. Surface and condition practiCAlly Perfect. Margin $1 / 4$ inch all around.

From the collection of the Duke of Buccleugh.

The Duchess of Gloucester was a daughter of Sir Edward Walpole; married the Earl of Waldegrave who died in 1763, and later the Duke of Gloucester, brother of George III. She was a prominent personage in the Walpole Correspondence.

\section{EDWARD FISHER}

Born in Ireland, 1730; died in London, about 1785. Was at first a hatter, but took to engraving; went to London; became a member of the "Incorporated Society of Artists," in 1766.

"Fisher must be allowed a high place for both breadth of treatment and delicacy of finish."-chAlONER sMith.

\section{FISHER, EDWARD}

100. Colley Cibier. Mezzotint.

Smith, No. 9.

Engraved after the painting by J. B. Vanloo. ONLY 


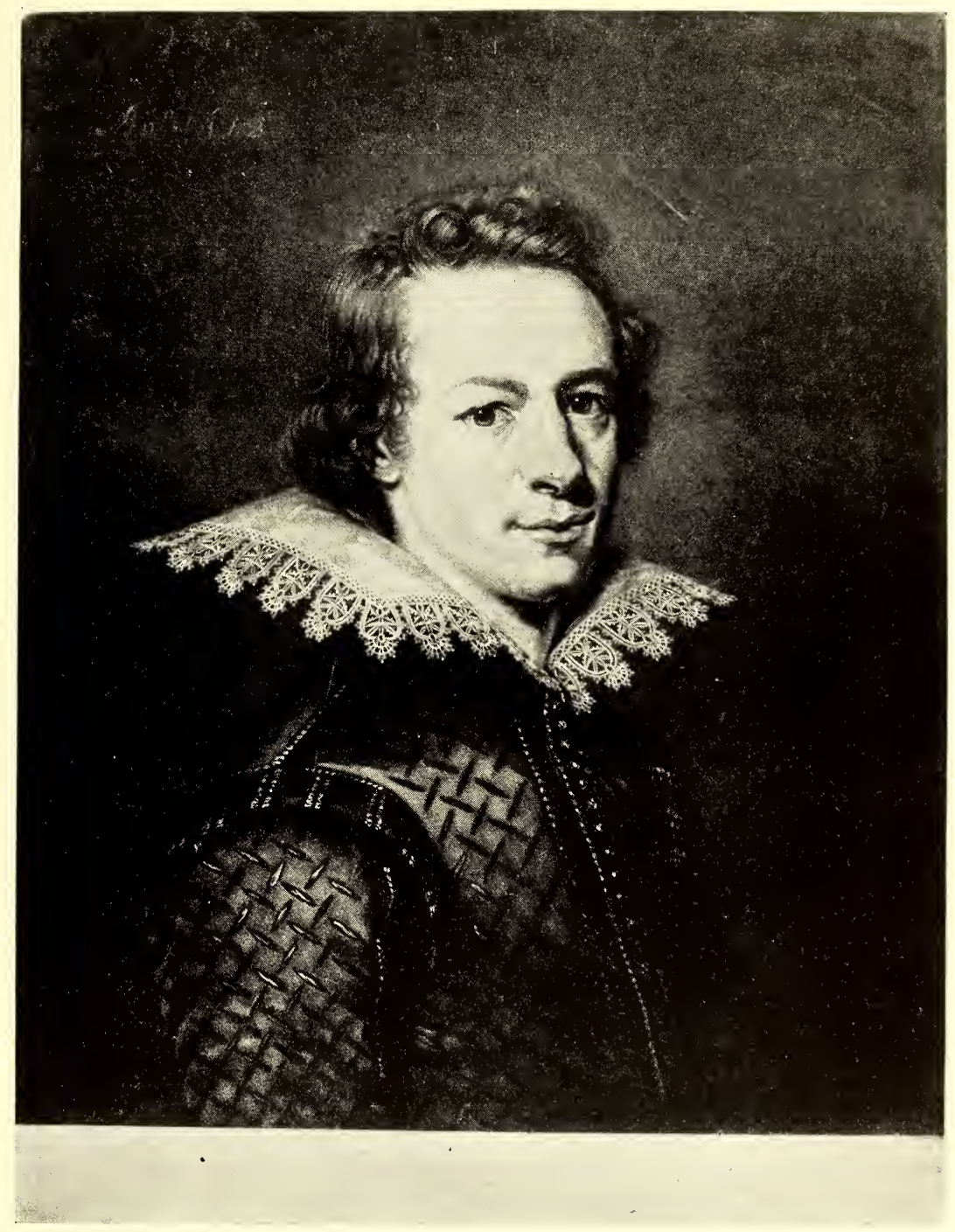

JOHN FINLAYSON. MEZZO'TINT

William Drumand

[No. 98] 
[No. 100-Continued]

state, with letters. Good impression. Surface and CONDITION PERFECT. Cut outside the plate-mark.

"Born in London, 1671; went on the stage; wrote several plays of which the "Careless Husband" is considered the best; the "Nonjuror" created a sensation at the time and procured him the place of Poet-Laureate in 1730. He was severely handled by Pope. Bromley calls the lady in the picture a Muse, but it is probably a portrait, perhaps that of his daughter Mrs. Charke."-J. c. smiтH.

FISHER, EDWARD

101. Mrs. Anne Oldfield. Mezzotint.

Smith, No. 49.

Engraved after the painting by Richardson. THIRD state, with the publisher's address. Good impression. Cut $1 / 8$ inch outside plate-mark on top and sides, trimmed inside plate-mark below, practically cutting off the publisher's address. Surface and condition good. A few thin spots.

\section{FISHER, EDWARD}

102. Lawrence Sterne. Mezzotint.

Smith, No. 56.

Engraved after the painting by Sir Joshua Reynolds. Third state, before the further retouch and the figures 76 at bottom to right. Fair impression. Surface good. Condition perfect. Margin $1 / 8$ inch all around. The best portrait of the author of "Tristan Shandy," and one of the most effective of all mezzotint portraits.

\section{PIERRE FOURDRINIER}

French engraver who flourished for thirty years in London. Engraved many plates for the embellishment of books, plays, and pamphlets. He died in London in 1758 .

\section{FOURDRINIER, PIERRE}

103. Jonathan SwlFt. Engraving.

Engraved after the painting by C. Jervas. Proof before all letters. Fine Clear impression, in perfeect condiTion. Cut on the plate-line. 


\section{First Session, Tuesday Evening, April 10th}

\section{PIERRE FREISLHEIN}

French engraver in color.

\section{FREISLHEIN, PIERRE}

104. Charles Henri, Comte D'Estaing. Engraving.

Aquatint engraving printed in colors after the artist's own painting. With the inscription and coat of arms. Fine impression, with engraved margin and register marks intact. Small mended tear on the right. Margin from $1 / 8$ to $1 / 2$ inch on top, bottom and left side; cut to plate-mark on right.

\section{CLAUDE FERDINAND GAILLARD}

Engraver and painter. Born in Paris, 1834; died in 1887. Entered the "Ecole des Beaux Arts," in 1850, and worked under Léon Cogniet. He won the Prix de Rome as an engraver in 1856.

\section{GAILLARD, CLAUDE FERDINAND}

105. The Man with the Pink. Engraving.

Beraldi, No. 25.

Engraved after the painting by Van Eyck. Completed state. Fine impression in perfect condition.

\section{GIORGIO GHISI}

Italian engraver. Born at Mantua in 1520. He was a pupil of Giulio Romano, and engraved many plates after Raphael and Michelangelo.

\section{GHISI, GIORGIO}

106. Raphael's Dream. Engraving.

Bartsch, No. $6 \%$.

Engraved after the design of Lucas Penni. Splendid ImPRESSION IN PERfECT Condition. Cut outside the plateline.

From the Debois, Durand, Firmin-Didot and Peoli collections.

This plate has also been called "The Melancholy of Michelangelo," from the fancied resemblance of the philosopher by the rock to that master. 


\section{JACOB GOLE}

Engraver in mezzotinto. Born, Amsterdam, 1660; died there, 1737.

\section{GOLE, JACOB}

10\%. Marie Sophie, Queex of Portugal. Mezzotint. Not in Smith.

Lettered impression. Fine impression. Surface and condition perfect. Cut on the plate-line.

\section{HENDRIK GOLTZIUS}

Born at Mühlbrecht, 1558; died at Haerlem, 1616.

"Among his own countrymen, Cort's breadth of style was best appreciated by Hendrick Goltzius, who came under the influence of his school in Rome. . The delight he takes in rendering curves, be they as bombastic as they will, is irresistible. . ."-HiND.

\section{GOLTZIUS, HENDRIK}

108. Holy Family. Engraving.

Bartsch, No. 20.

Engraved after his own design in 1593. Fine impression, in PERFECT Condtion. Margin $1 / 8$ inch all around.

One of a set of six plates, known as the "Masterpieces of Goltzius." They were executed in the style of each of the masters he wished to imitate, Dürer, Raphael, Van Leyden, etc. This one is in the manner of Barocci.

\section{GOLTZIUS, HENDRIK}

109. The Flagellation. Engraving.

Bartsch, No. 32.

Engraved in the manner of Lucas van Leyden. Fair impression, ix GooD condition. Cut outside plate-line.

\section{GOLTZIUS, HENDRIK}

110. Noel de la Farlle. Engraving.

Bartsch, No. 212.

The Wife of N. de la Faille. Engraving.

Bartsch, No. 213.

One signed on the plate with the monogram, the other 


\section{First Session, Tuesday Evening, A pril 10th}

[No. 110-Continued]

with the name. Superb mipressions, in perfect condiTION. One very small thin spot.

From the collections of Julian Marshall and H. S. Theobold.

Together, 2 pieces.

\section{CHARLES STORM VAN'S GRAVESANDE}

Contemporary Dutch etcher. Born at Breda in 1841; living at Brussels. Félicien Rops first suggested to him the use of the needle, which he used with such skill and application that he has now reached the position of Dean among Dutch etchers

\section{GRAVESANDE, CHARLES STORM VAN'S}

111. Beaching the Boat. Etching.

Signed remarque proof ox Holland paper, with full margins.

ON the Vecht. Etching.

Signed ARTIST'S PROOF ON JAPAN PAPER, with full margins.

Piers at Zeeburg. Etching.

Signed artist's proof ox HollaANd Paper, with full margins.

Together, 3 pieces.

\section{JOHN GREENWOOD}

Painter and mezzotint engraver. Born at Boston in 1729; died at Margate, 1792. In 1752 he emigrated to Surinam and thence to Holland, arriving in England in 1763. Here he exhibited engravings at the Incorporated Society of Artists from 1764 to 1776 , when he became an auctioneer.

\section{GREENWOOD, JOHN}

112. Portrait of an Old Max (Rembrandt's Father). Mezzotint.

Smith, No. 9.

Engraved after the painting by Rembrandt. First state, proof before all letters. Fine rich impression. In 
[No. 112-Continued]

perfect condition. Good surface. Margin $1 / 8$ inch all around.

Greenwood was one of the several artists born in America who emigrated to Europe to practice their craft. The original of the picture is in the "Metropolitan Museum of Art," New York.

[See Reproduction $]$

\section{JOSEPH GROZER}

English mezzotint engraver; born about 1755. He practised in London, and probably died before 1799 .

\section{GROZER, JOSEPH}

113. Mrs. H. Mackevzie and Child. Mezzotint.

Smith, No. $1 \%$.

Engraved after the painting by Sir Joshua Reynolds. Second state, with inscription. Fine impression. Fair surface. Good condition cut just outside plate-mark. Several slight mended places.

To this lady Walter Scott addressed the following lines in 1818,"And thou, gentle dame, who must bear to thy grief, For thy clan and thy country, the cares of a chief, Whom brief rolling moons in six changes have left, Of thy husband, and father, and brethern bereft; To thine ear of affection how sad is the hail That salutes thee the Heir of the line of Kintail."

\section{SIR FRANCIS SEYMOUR HADEN}

Eminent English etcher and surgeon. Born at London, 1848; died there in 1910. President of the "Royal Society of Painter Etchers."

"Seymour Haden is pre-eminently a landscape etcher, resembling, certainly in this respect, the greatest number of etchers. Whatever the landscape be, it is always, it seems, landscape of character and landscape that the artist has enjoyed."-FrEDerick wEDMore.

\section{HADEN, SIR FRANCIS SEYMOUR}

114. Sunset in Ireland. Etching.

Harrington, No. 51.

Etched in 1863. Signed on the plate, and in pencil,- 


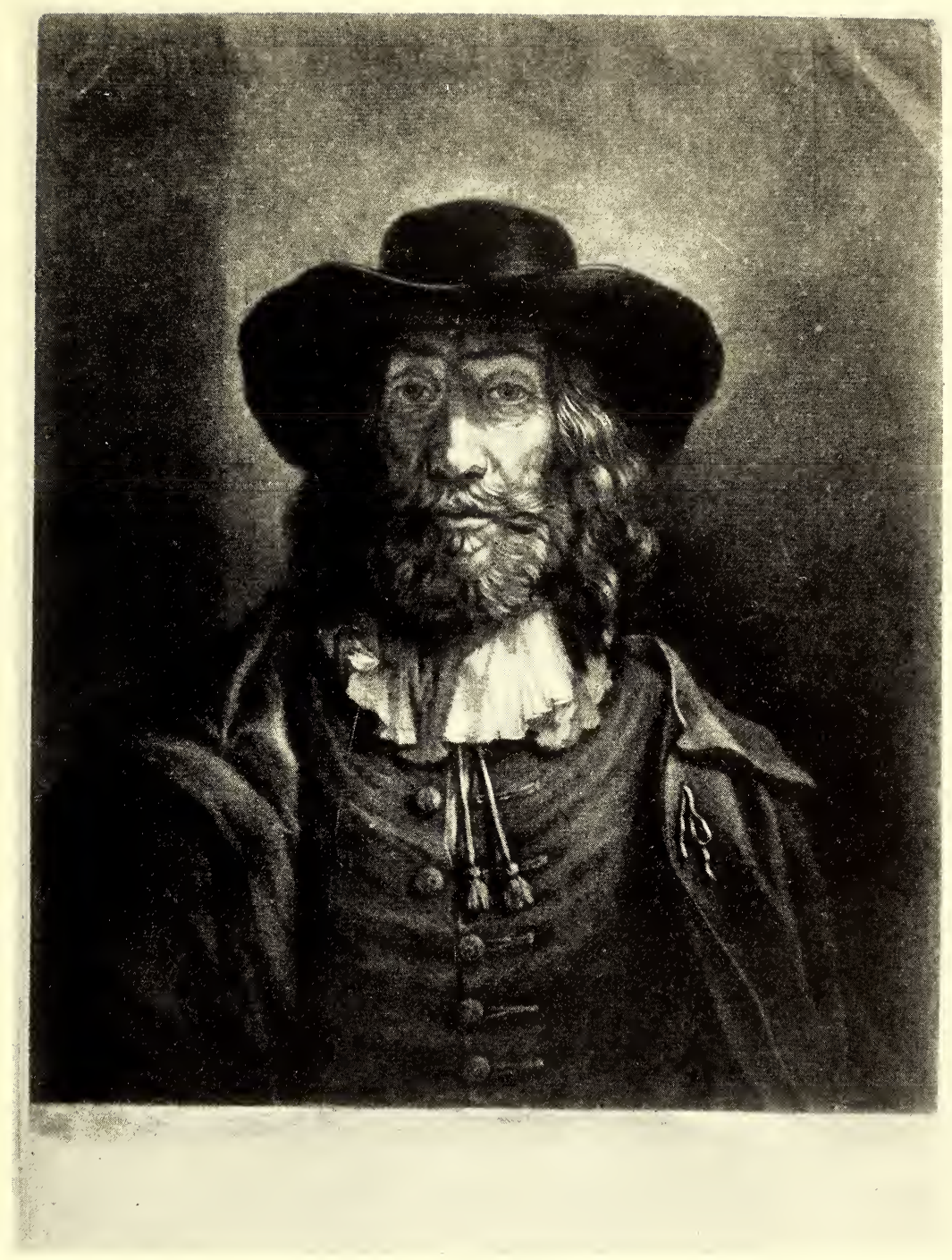

JOHN GREENWOOD. MEZZOTINT

Rembrandt's Father

[No. 112] 
[No. 114-Continued]

"Seymour Hayden." Full rich impression of the SeCond state. Ample margins. Very fine and rare.

"A Sunset in Ireland is Hayden's best work in dry-point, and it certainly deserves its reputation of one of its author's masterpieces. The quiet, peaceful sunset behind the dark masses of trees makes a plate of exquisite beauty. 'There are great differences in the various states, so that a choice among them is extremely difficult. The rich, dark, lateevening effect of the second state is quite as fine in its way as the lighter and more delicate early-evening effect of the earlier impressions."--ALEERTON CURTIS.

[See Reproduction]

\section{AXEL HERMAN HAIG}

Celebrated Swedish etcher. Born in 1835 and working in London. Famous for his etchings of architectural subjects. He was the teacher of Anders Zorn.

\section{HAIG, AXEL HERMAN}

115. Extrance to the Poet's Corner, Westuminster. Etching. Armstrong, No. 45.

Signed ARTIST's PRoOF.

Framed.

\section{HAIG, AXEL HERMAN}

116. The Fountain of St. George. Etching.

Armstrong, No. $4 \%$.

Signed artist's proof. IN PERfect condition and with 11/2 inches margins. Limited to 100 Proofs.

This fountain is at Rothenberg in Bavaria, one of the most mediæval of German mediæval towns.

\section{HAIG, AXEL HERMAN}

11\%. Waiting for the Ferry, Lübeck. Etching.

Armstrong, No. 48.

Signed Artist's proof. Limited to 250 proofs.

Framed. 


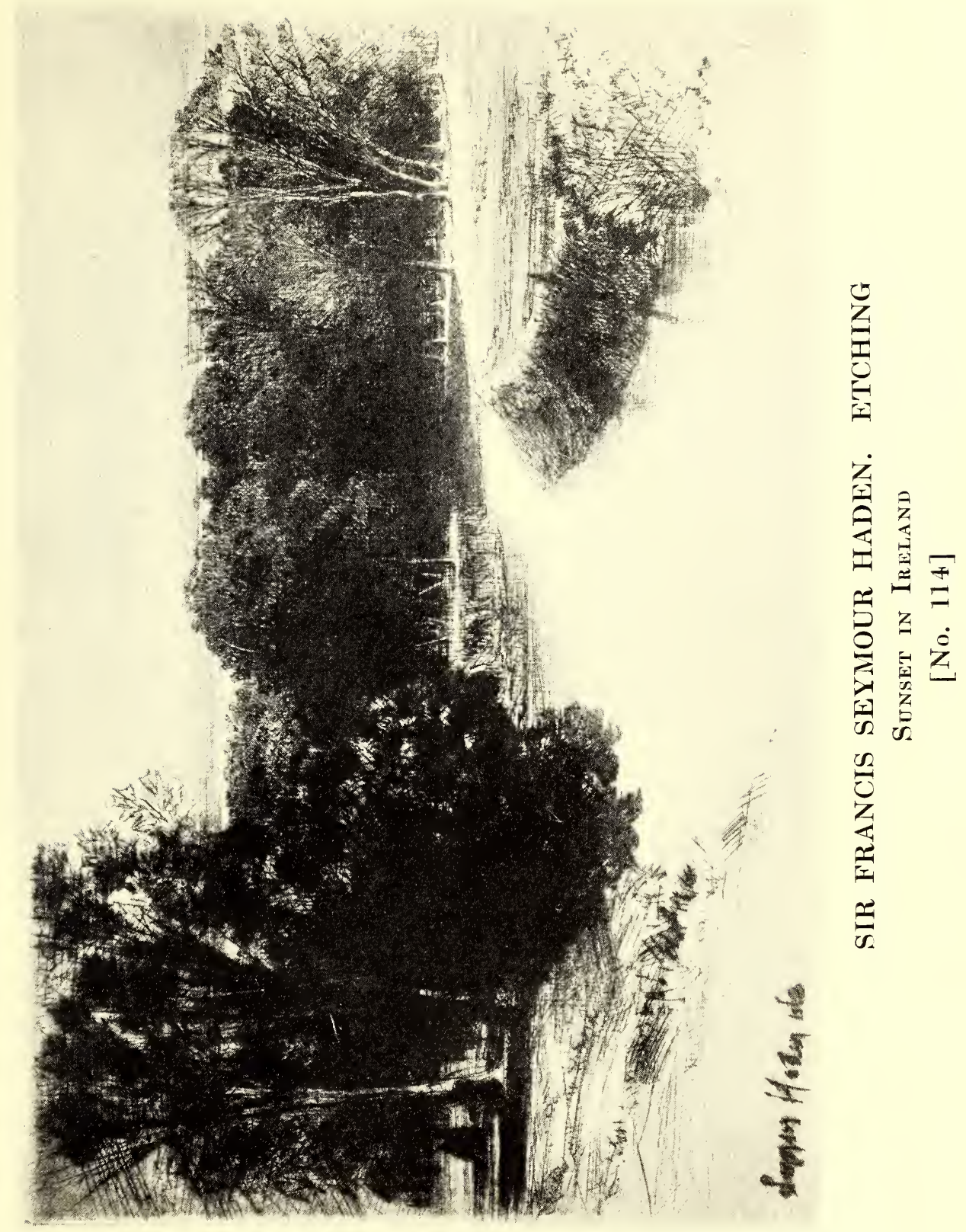




\section{First Session, Tuesday Evening, A pril 10th}

HAIG, AXEL HERMAN

118. Magdalen College, Oxford. Etching.

Armstrong, No. 52.

Signed ARTIST's PRoof. Limited to 500 proofs.

The well-known Magdalen Tower as seen from Addison's

Walk, Oxford.

Framed.

HAIG, AXEL HERMAN

119. Burgos Cathedral, Interior. Etching.

Armstrong, No. 65.

Signed ARTist's Proof. In good condition and with ample margins.

"This etching of the Interior of Burgos Cathedral may fairly be described as the best known and most highly valued of Mr. Haig's etchings of cathedral interiors."-E. A. ARMstrong.

HAIG, AXEL HERMAN

120. Extrance to the Mosque of Mohammed Bey, Cairo. Etching.

Armstrong, No. 81.

Signed artist's proof. Limited to 200 proofs.

Framed.

HAIG, AXEL HERMAN

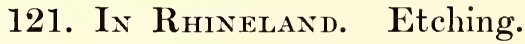

Armstrong, No. 83.

Signed ARTist's Proof. Limited to 200 proofs.

Framed.

\section{HAIG, AXEL HERMAN}

122. Durham Cathedral. Etching.

Armstrong, No. 99.

Signed artist's proof on imperial Japan PAPER, with full margin. Etched in 1893. Very slightly rubbed in one place on the margin.

It was Durham Cathedral that Dr. Johnson pronounced to be of "rocky solidity and indeterminate duration." 


\section{First Session, Tuesday Evening, A pril 10th}

HAIG, AXEL HERMAN

123. Tarragona Cathedral. Etching.

Armstrong, No. 116.

SigNed ARTIST's PROOF. Limited to 250 proofs.

Framed.

\section{HAIG, AXEL HERMAN}

124. Palencia. The Altar of Visitation. Etching. Armstrong, No. $11 \%$.

Signed artist's proof. Limited to 350 proofs.

Framed.

\section{WILLIAM HOLE}

English engraver who flourished about the year 1613. He was chiefly employed by the booksellers.

\section{HOLE, WILL}

125. Michael Drayton. Engraving.

Good impression with letters. Fair condition. Several thin places. Cut on the plate-mark. RARE.

\section{WENZEL HOLLAR}

Draughtsman and etcher. Born at Prague, July 13, 1607; died at London, May 28, 1677. Left Prague in 1627, studied in Frankfort under M. Merian, worked in Strasbourg from 1629 to 1633 .

HOLLAR, WENZEL

126. Albrect Dürer. Etching.

Parthey, No. 1390.

Etched after the painting by Albrecht Dürer. ONLY state. Good impression, in good condition. Cut on the plate-line. 
First Session, Tuesday Evening, April 10th

HOLLAR, WENZEL

12\%. William Dugdale. Etching.

Parthey, No. 1392.

Etched after the artist's own design. Only state. Splendid impression, in perfect condition. Margin 1 to 2 inches all around. RARE.

A fine portrait of the celebrated antiquarian.

HOLLAR, WENZEL

128. Charles II. Etching.

Parthey, No. 1442.

Etched after the painting by Sir Anthony Van Dyck. First state, before the words "Natus Ao. 1630," were included in the regular line. VERY FINE IMPRESSION IN PERFECT Condition. Cut just inside the plate-line.

HOLLAR, WENZEL

129. Charles II. Etching.

Parthey, No. 1442.

Etched after the painting by Sir Anthony Van Dyck.

Second state, before the address of Meyssens. Fine IMPRESSION IN PERFECT CONDITION. Cut just outside the plate-line.

From the Julian Marshall collection.

HOLLAR, WENZEL

130. Charles II. Etching.

Parthey, No. 1442.

Etched after the painting by Sir Anthony Van Dyck. Third state, before the address of Meyssens was effaced. Fine impression in perfect condition. Margin $1 / 2$ to $11 / 4$ inches all around.

From the Broadhurst collection. 


\section{First Session, Tuesday Evening, April 10th}

HOLLAR, WENZEL

131. William Oughtred. Etching.

Parthey, No. 1477.

Etched from life at Antwerp in 1646. Only state. Splendid impression in good condition. One or two slight thin places. Cut on the plate-mark.

From the collection of Seymour Haden. Haden in his lectures and writings always spoke very highly of Hollar and considered him one of the greatest etchers who ever lived. Oughtred the mathematician at Cambridge was born in 1573 and died in 1660 .

HOLLAR, WENZEL

132. Henry Howard, Earl of Surrey. Etching.

Parthey, No. 1509.

Etched after the painting by Hans Holbein. First State, Proof Before letter. Splendid impression in Perfect condition. Margin $1 / 8$ inch top and sides, cut just inside the plate-line at bottom. VERY FINE ANd RARE.

\section{HOLLAR, WENZEL}

133. The Dead Hare. Etching.

Parthey, No. 2058.

Etched after the painting by Peeter Boel. Oxcy state. Very fine Impression in perfect condition. Cut just outside the plate-mark.

\section{DANIEL HOPFER}

Worked at Augsburg from 1493 until 1536.

"Daniel Hopfer. . . was certainly one of the first, if not the earliest, of the German artists to practice etching in our sense of the word. He used it, like many another before him, for ornamenting armour and guns." -HIND

HOPFER, DAVID

134. Three Women Attacking a Demon. Engraving.

Bartsch, No. 7 .

Signed with the monogram,-_ $D$. $H$." VERY FINE IMPRESSION IN PERFECT CONDITION. 


\section{RICHARD HOUSTON}

Born in Dublin, 1722; died in London, 1775. He was apprenticed to Brooks, and thus became a fellow-pupil with MacArdell, whom at the outside of his career he was considered to rival, if not even surpass, in spirit and fire.

"His manner was bold and vigorous when his subjects required such treatment, as in the rugged pictures of Rembrandt."-ALFRED whitMan.

\section{HOUSTON, RICHARD}

135. John Bunyon. Mezzotint.

Smith, No. 18.

Engraved after the painting by T. Sadler. Only state, with letters. Good impression with $1 / 8$ inch margin all around.

\section{HOUSTON, RICHARD}

136. Voltaire. Mezzotint.

Smith, No. 119.

Engraved after the painting by L. Sel. Ondy state.

Good impression. Surface and condition very good. Margin 1/4 inch all around. Mounted down for framing.

\section{PETER ISSELBURG}

German engraver. Born at Cologne about 1580, was probably a pupil of Crispin de Passe. He was much employed by booksellers and died in Nuremberg in 1630 .

\section{ISSELBURG, PETER}

13\%. Henry VIII. Engraving.

Fine impression with inscription. Cut on the plate-mark and remargined.

James of England. Engraving.

Published by Peter Isselburg. Splendid impression in PERfect Condition. Full margins.

James of England. Engraving.

"Printed and sould by P. Stent." Good impression with inscription. Condition perfect. Cut on the plate-line. Together, 3 pieces. 


\section{RICHARDSON JACKSON}

Contemporary English mezzotint engraver of the Cousins school.

\section{JACKSON, RICHARDSON}

138. Lady Gertrude Fitzpatrick. Mezzotint.

Engraved after the painting by Sir Joshua Reynolds. First state, proof before all letters. Good impression in good condition. Margin 1 inch all around. Mounted down for framing.

\section{CHARLES JACQUE}

French painter and etcher. Born at Paris in 1813; died at Barbizon in 1894. His original etchings did not appear until about 1841.

\section{JACQUE, CHARLES}

139. Le Depart. Etching.

Signed on the plate,-“Ch. Jacque." First state proof before letters. Fine impression, on India paper with full margins.

Les Petites Vachères. Etching.

Signed on the plate-“Ch. Jacque." First state proof before letters. Fine impression on India paper with full margins. Mounted down for framing.

Together, 2 pieces.

\section{JOHN JONES}

John Jones was born probably after 1740. He practiced in London and was appointed engraver to the Prince of Wales and the Duke of York. His works are in stipple as well as in mezzotint, but it is on those in the latter manner that his reputation rests. He died in 1797.

\section{JONES, JOHN}

140. James Bosweli. Mezzotint.

Smith, No. 8.

Engraved after the painting by Sir Joshua Reynolds. First state, scratched letter proof. Splendid im- 


\section{First Session, Tuesday Evening, April 10th}

[No. 140-Continued]

Pression. Surface and condition very good. Margin cut on plate mark at top and sides, $1 / 4$ inch margin at bottom. Very fine and RARE.

The best portrait of the celebrated biographer.

"The Charles James Fox and the James Boswell are among the most powerful and desirable prints of Reynold's male prints."-Mr. c. SALAMAN.

JONES, JOHN

141. Black Monday, or the Departure for School. Mezzotint.

Not in Smith.

Engraved after the painting by W. R. Bigg. Open letter proof. Splendid impression. Surface and Condition perfect. Margins reinforced. A slight erasure in the inscription. Very fine aNd RaRe.

Companion piece to Dulce Domum.

\section{GEORGE KEATING}

Irish engraver. Born in 1762 , studied with W. Dickinson, and practised in London between 1794-1799 in mezzotint and stipple.

\section{KEATING, GEORGE}

142. Nurse and Children in the Fields. Mezzotint.

Not in Smith.

Engraved after the painting by George Morland. Lower margin cut to engraved surface and false plate-margin added from some uncleaned engraver's proof, surface and condition otherwise perfect. Good impression.

"But it is as an interpreter of Morland that Keating is seen at his best, Children playing at Soldiers being a delicious gem, while scarcely less admirable are The Angling Party and Nurse and Children in the Fields."- 


\section{First Session, Tuesday Evening, April 10th}

\section{LUCAS KILIAN}

Engraver. Born at Augsburg, 1579; died there, 163\%. Pupil of his stepfather, D. Custos. Member of a large and important family of engravers.

\section{KILIAN, LUCAS}

143. Albrecht Dürer. Engraving.

Engraved after the painting by Albrecht Dürer. Lettered impression in perfect condition.

Albrecht Dürer. Engraving.

Engraved by G. M. Preissler after the painting by Albrecht Dürer. Splendid impression, proof before all letters in perfect condition.

From the Artaria Collection.

'Together, 2 pieces.

\section{CHARLES KNIGHT}

Born in London, about 1743; died there about 1825.

\section{KNIGHT, CHARLES}

144. Blixd Max's Buff. Stipple Engraving.

Engraved after the painting by William Hamilton. Good impression. IN PERFECT CONDITION.

Framed.

\section{WILLIAM LANE}

Portrait painter. Born in 1746; died at Hammersmith, 1819. For some years he practised as a gem engraver, but afterwards devoted himself to portraits in crayons.

\section{LANE, WILLIAM}

145. Mrs. Abingtox. Stipple Engraving.

Engraved after the drawing by R. Cosway. Fine deliCate impression. Stippled letter proof. Condition PerFECT. Cut on the plate-line. 


\section{ROBERT LAURIE}

Mezzotint engraver and printseller. Born in London in 1740; died about 1804. In 1776 he received a premium from the "Society of Arts" for an invention in the aid of printing in color.

\section{LAURIE, ROBERT}

146. Mrs. Wrightex. Mezzotint.

Mr. Garrick. Mezzotint.

Smith, No. 1.

From the series of 12 actors engraved after R. Dighton. Fair impressions, in good condition. Margins 1/16 inch all around.

Together, 2 pieces.

\section{LAURIE, ROBERT}

14\%. Georgiana, Duchess of Devonshire. Mezzotint.

Smith, No. 17.

Engraved probably after the painting by Richard Cosway. First state, before any inscription. Very fine impression. Surface and condition perfect. Margin $1 / 4$ inch all around.

A similar print has been engraved by Bartolozzi from the design of Lady Diana Beauclerc.

\section{B. LE CLAIR}

French engraver of the early 19th century. Influenced by Bartolozzi.

\section{LE CLAIR, B.}

148. Lafayette. Stipple engraving.

Engraved after the painting by L. Barre. Proof Before title. Fine impression printed in sanguine. Condition very good. Original margins. 


\section{First Session, Tuesday Evening, A pril 10th}

\section{EDWARD LE DAVIS}

Painter and engraver. Born in Wales about 1640. He was articled as a pupil to Loggan, but not being treated to his satisfaction, he fled to France. In Paris he resumed the practice of his art. On his return he engraved some portraits and other subjects.

\section{LE DAVIS, EDWARD}

149. Louise, Duchess of Portsmouth. Engraving.

Engraved after the painting by Sir Peter Lely. Good impression, with letters. Fair condition, several thin places in the corners. Cut on plate-line.

\section{PIERRE LOMBAR'T}

French designer and engraver. Born at Paris, about 1620; where he died in 1681. He is said to have learned the principles of design under Simon Vouet

\section{LOMBART, PIERRE}

150. Јонn Donne. Engraving.

Fine impression, with inscription. Condition good. Cut on plate-line and remargined.

\section{MELCHIOR LORCH}

Danish painter and engraver. Born at Flensburg in 1527. He worked first with a goldsmith at Lübeck and later travelled much, even to Turkey, where he engraved the portrait of the Sultan. He died at Rome, probably about 1590 .

\section{LORCH, MELCHIOR}

151. Martin Luther. Engraving.

Engraved in 1548. Fine impression, in Perfect condTion. Cut just outside the plate-mark. 


\section{THOMAS GOFF LUPTON}

Mezzotint engraver. Born in London in 1791, studied under George Clint. In 1822 he received the gold Isis medal of the "Society of Arts" for his application of soft steel to the process of mezzotint engraving. He died in 1873 .

\section{LUPTON, THOMAS GOFF}

152. Fawcett and Kenble as Captain Copp and the King. Mezzotint. Not in Smith.

Engraved after the painting by Clint. Scratched Letter proof before title. Very fine impression. Surface and condition good. Slightly stained and folded. Margin $1 / 4$ inch all around.

\section{JAMES MCARDELL}

English mezzotint engraver. Born in Dublin, 1729; died in London, 1765. Pupil of John Brooks, with whom he came to London about 1747. One of the best of the earlier mezzotinters.

\section{MCARDELL, JAMES}

153. Samuel Richardson. Mezzotint.

Smith, No. 152.

Engraved after the painting by Joseph Highmore. Possibly an INTERMEDIATE STATE with the names of the artists but before the verses. One inch of the lower plate-margin lacking, a space which could hold 14 lines of verse only with much crowding. Impression fair, surface a little rubbed.

The best portrait of the author of "Pamela and Clarissa."

\section{MCARDELL, JAMES}

154. Horace Walpole. Mezzotint.

Smith, No. 186.

Engraved after the painting by Sir Joshua Reynolds. Second state, with inscription. Fine impressions. Surface and condition perfect. Margin 3/4 inch all around. A fine portrait of the celebrated critic and connoisseur. 


\section{First Session, Tuesday Evening, A pril 10th}

\section{MCARDELL, JAMES}

155. Girl with Flute. Mezzotint.

Not in Smith.

Engraved after the painting by I. Molenaar. Good impression with letters. Surface and condition practically perfect. Margin $1 / 4$ inch all around. Mounted down for framing.

\section{MCARDELL, JAMES}

156. Old Woman Reading. Mezzotint.

Not in Smith.

Engraved after the painting by Rembrandt. Proof Before title. Splendid impression. Surface fair. ConDition perfect. Margin $1 / 16$ inch all around.

\section{JOHANN AUGUST EDWARD MANDEL}

Born in Berlin, 1810; died there, 1882. The last of the great line-engravers.

\section{MANDEL, JOHANN AUGUST EDWARD}

15\%. Charles I. Engraving.

Apell, No. 33.

Engraved after the portrait by Sir Anthony Van Dyck.

First state, with the artist's name but before other let-

ters. Fine impression with fUll margins.

\section{MANDEL, JOHANN AUGUST EDWARD}

158. Raphael at the Age of 15. Engraving.

Apell, No. 36.

Engraved after the painting by Raphael. Proof ov

India paper, before the title. Splendid impression in perfect condition and in the original margins. Fine AND RARE.

With Mandel's blind stamp and from the collection of Carl Schloesser. 


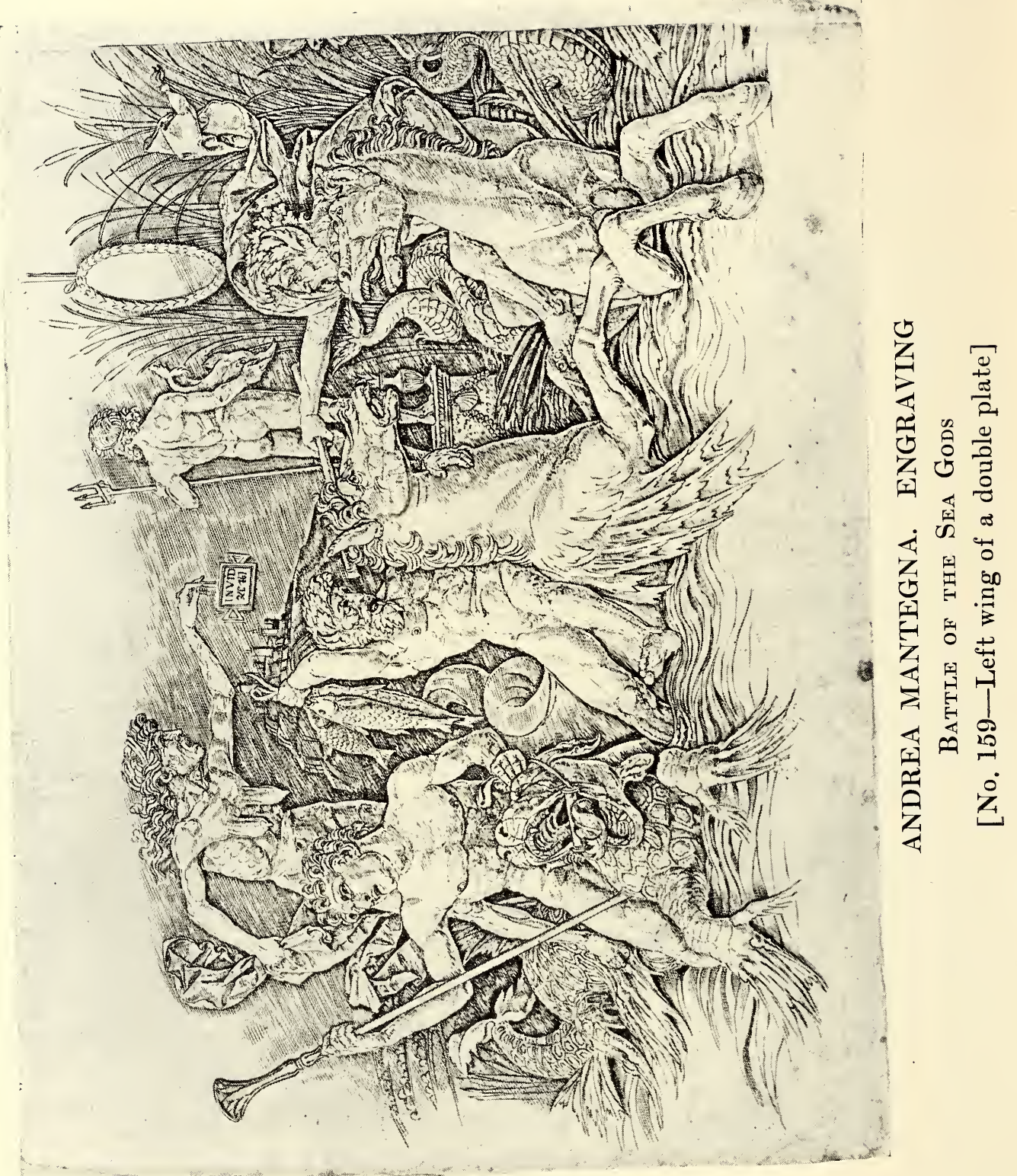




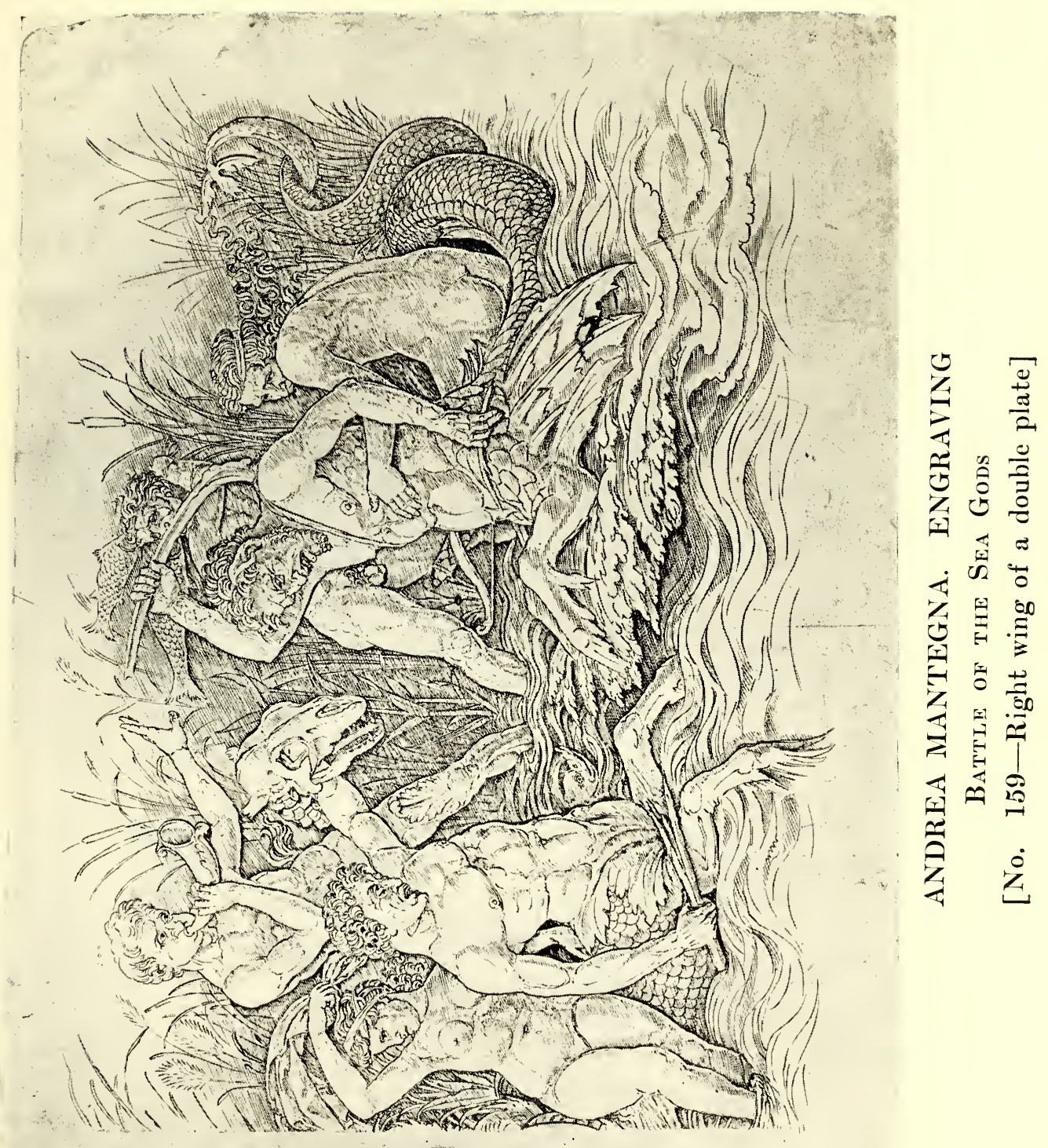




\section{ANDREA MANTEGNA}

Born at Vincenza, 1431; died at Mantua, 1506. In his work for the first time, engraving became monumental, and it is probable that he had a great effect upon Diirer. Mantegna's engravings remained the model for all subsequent artists in upper Italy until the time of Marcantonio Raimondi; that is to say, until the influence of the German School, and especially of Dürer's technique, gave the development of engraving in Italy a new direction.

\section{MANTEGNA, ANDREA}

159. The Battle of the Sea Gods. Engraving. Bartsch, No. 18.

The two portions of the frieze complete. Engraved after the artist's own design. Splendid impression printed with the grayish ink with which some of the finest impressions were printed. The left hand part is just the slightest shade more brilliant than the right hand portion, but one seldom if ever sees so perfectly matched a pair as this. In absolutely perfect Condition, SHOwing alL THE ACCIDENTAL SCRATCHES ON THE PLATE AND SHOWING ThE PLATE-MARK INTACT ON ALL sides. In some cases there are margins from $1 / 8$ to $3 / 8$ inches outside the platemark. Impressions in such immaCulate condition and PRESERVATION OCCUR SO RARELY AS TO BE ALMOST UNIQUE.

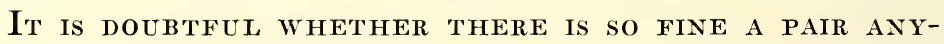
Where in the COUNTry. The impressions in one of the finest and best known collections of early Italian engravings, that of the "British Museum," are both of them cut. Extremely fine and of the UTMost rarity.

In the Albertina there is a drawing by Dürer after one part of this print which has the date 1494, and which shows that this engraving was made before that date. Each section is herein reproduced on a separate page, in order to show full plate-mark, and margins of same.

"The idea of portraying the unbridled physical joy of living, in contrast to the glorification of the ideal delights of the existence, in the pictures executed for Isabella's Studio, may have occurred to Mantegna. These are not the mighty gods of Olympus, but the inferior deities of Nature, of the earth and the sea, who acknowledge none of the higher obligations, and who display unchecked their wanton elemental nature, giving a loose rein to all the exuberance of their joy in life."-P. KRISTELlER,-Andrea Mantegna.

[See Reproductions of Both Sections] 


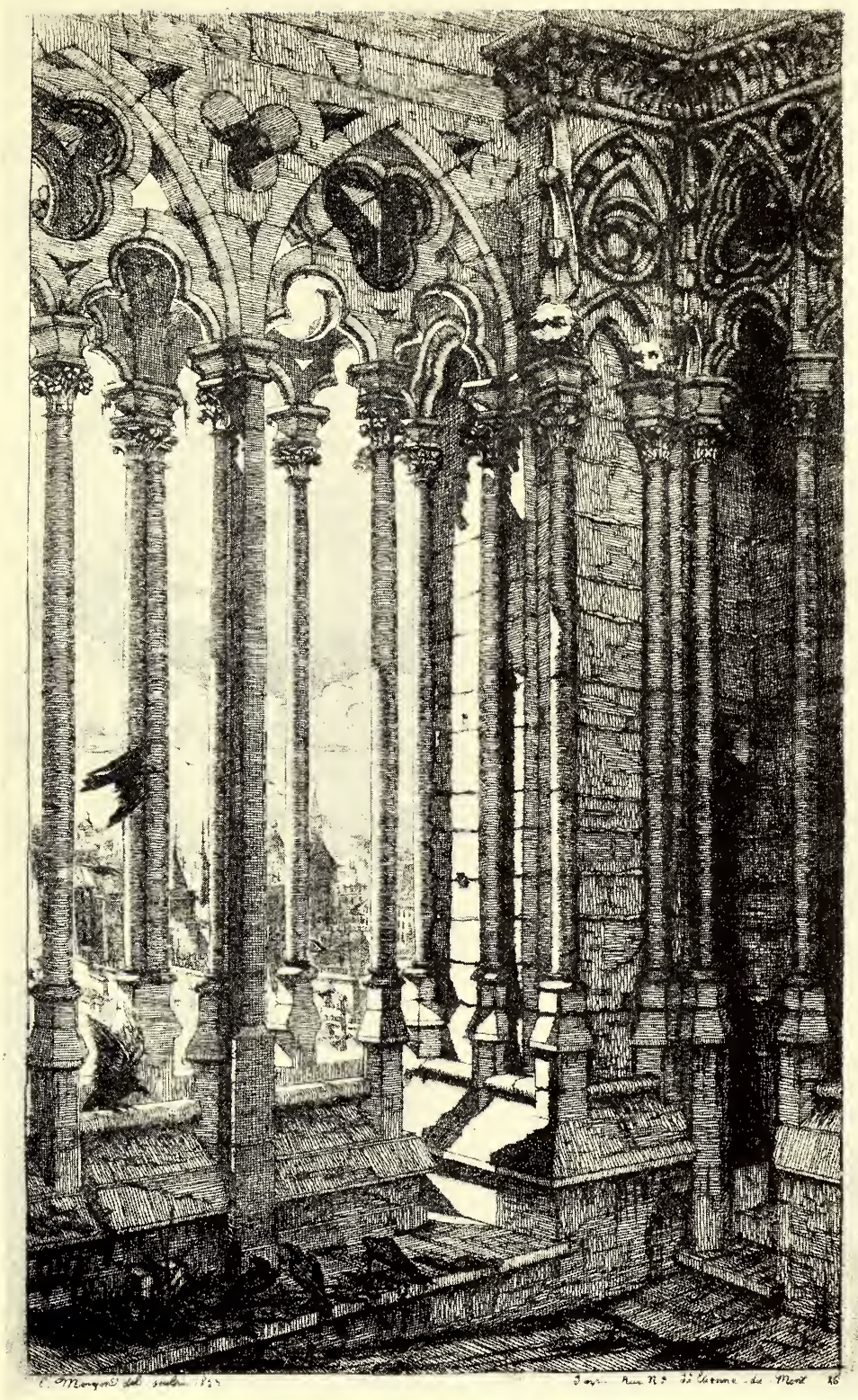

CHARLES MERYON. ETCHING

La Galerie, Notre Dame

[No. 161] 


\section{JEAN LOUIS ERNEST MEISSONIER}

Celebrated French painter, etcher, and vignettist. Born at Lyons in 1815; died at Paris in 1891.

"The several etchings which for him were only an intermezzo in his work, are among the most precious in the history of engraving."-BERALDI.

\section{MEISSONIER, JEAN LOUIS ERNEST}

160. Le Fumeur. Etching.

Beraldi, No. 13.

Signed on the plate,-_E. Meissonier." Regular impression on India paper with full margin.

\section{CHARLES MERYON}

Celebrated French etcher. Born in Paris in 1821; died there in 1868.

"But we must turn now to a great poet-etcher, one of the greatest masters that the copper-plate has ever known and one of the most tragic and piteous figures in the history of art. When Charles Meryon after his sea-wanderings and his failure as a painter, found his true vocation with needle and mordaunt, his strange weird genius, haunted by the mysterious beauty that the centuries had stamped upon Paris, expressed itself through an artistic record of her old buildings that was soundly while imaginatively picturesque, yet personally reflective to an extraordinary degree."-MaLcolm SALAMAN.

\section{MERYON, CHARLES}

161. La Galerie, Notre Dame. Etching. Delteil, No. 26.

Signed on the plate in the margin,- “C. Meryon del. sculp. 1853." Third state before the address was effaced and title added. Superb impression on papier VERDATRE PRINTED BY THE ARTIST. In perfect condition except for one or two slight pin-pricks. One inch margins all around. ExceEdingly fine and rare.

This view was described by Victor Hugo in "Notre Dame de Paris" in the chapter entitled "A Vol d'Oiseau."

\section{[See Reproduction $]$}




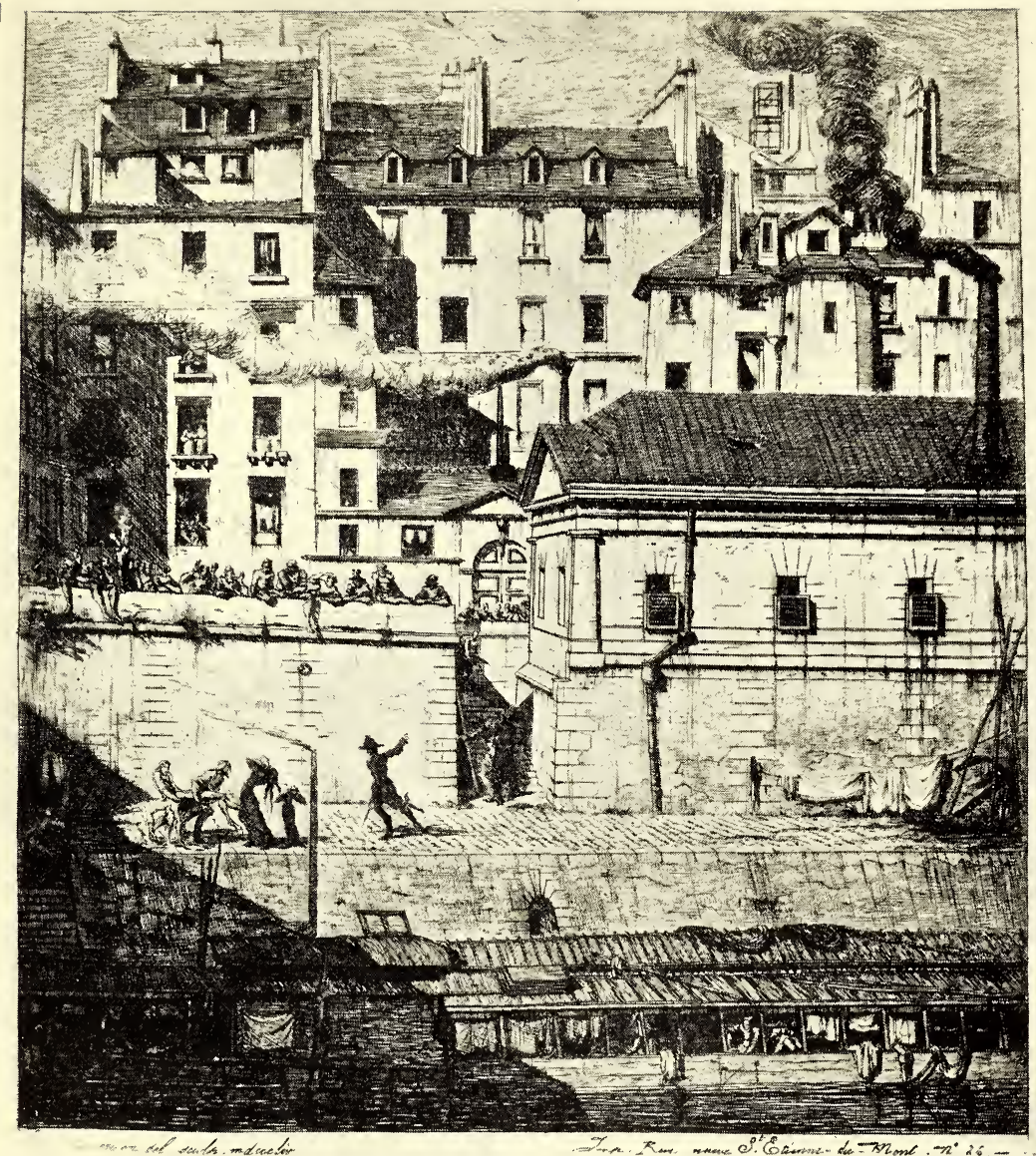

CHARLES MERYON. ETCHING

La Morgue

[No. 163] 
First Session, Tuesday Evening, A pril 10th

\section{MERYON, CHARLES}

162. I. Pompe, Notre Dame. Etching.

Delteil, No. 31.

Signed on the plate in the margin,- "C. Meryon ft." Sixth state, with the oblique lines on the clouds to the left but before the title in margin below. Splendid impression on papier verdatre. Printed by the artist. IN IMMaCulate Condition and With Full Margins. ExTREMELY FINE AND RARE.

Proofs printed on papier verdatre are considered especially desirable by Meryon collectors.

\section{MERYON, CHARLES}

163. La Morgue. Etching.

Delteil, No. 36.

Signed on the plate,-“C. Meryon del. sculp." Fourth state, before the title was added. Brilliant impression in brownish ink. Printed by Meryon. In Perfect Condition and with wide margin. VERY FINE AND RARE. Meryon's poem on this subject in W. A. Bradley's translation runs as follows:

"Come, view, ye passerby,

Where her poor children lie;

A mother charitable,

This Paris that you see

To them, at all times free,

Gives both a bed and table. . . ."

[See Reproduction] 


\section{JEAN FRANÇOIS MILLE'T}

Born in the little village of Gruchy, on the Norman coast, October 4, 1814. Died at Barbizon, January 20, 1875.

"A man who had given his whole life to etching only, who had never thought of painting, and had never cared for those effects proper to painting and not to etching, could not have been more truly and markedly a born etcher than Millet showed himself to be-few though were the plates and many though were the canvases he worked upon. To depend upon lines, not tones, for expression; to make every line 'tell,' and to use no more lines than are absolutely needed to tell exactly what he wants to say; to speak strongly, concisely, and to the point; to tell us much while saying little; to suggest rather than to elaborate, but to suggest in such a way that the meaning shall be very clear and individual and impressivethese are the things the true etcher tries to do. And these are the things that Millet did with a more magnificent power than any man, perhaps, since Rembrandt. Other modern etchings have more charm than hisnone have quite so much feeling. Others show more grace and delicacy of touch-none show more force or certainty, and none a more artistic "economy of means." -MRS. SCHUYLER VAN RENSSELAER.

\section{MILLET, JEAN FRANÇOIS}

164. Peasant with Wheelbarrow. Etching.

Delteil, No. 11.

Signed on the plate,-“J. F. Millet." Third state, with the bevelled plate but before the complete erasure of Delatre's address. Beautiful impression in WARM RICH Brownish ink. Proof printed by Delatre and espeCIALly MARKED BY HIM IN PENCIL,-“"tres belle Epreute Aug. Delatre." In Perfect condition and with full margin. VERY FINE AND RARE.

"A laborer, in a straw hat and a knitted waist-coat, is barrowing a load of manure through a gateway opening from the yard into the orchard. In the background is a well, shaded with shrubs and pendent boughs. Beyond the orchard gate are bee-hives; fruit trees dip and bend over the orchard wall; and over everything is the sense of a hot, still, drowsy summer afternoon."-w. E. HENLEY,-"Jean François Millet."

\section{MONOGRAMIS'T C. B.}

This master engraved in the style of D. Hopfer, and in view of the fact that the Hopfer mark is nearly always to be found in his plates, it is assumed that he was a member of the Hopfer family.

\section{MONOGRAMIST C. B.}

165. Charles V. and His Brother Ferdinand. Etching.

Bartsch, No. 3.

Splendid mpression in perfect condition. Cut outside plate line. Very fine and rare. 


\section{JOHANN GO'T'THARD VON MÜLLER}

Born at Bernhausen, near Stuttgart, 1747; died in Stuttgart, 1830. Pupil of J. G. Wille.

\section{MÜLLER, JOHANN GOTTHARD VON}

166. The Battle of Bunker Hill near Boston. Engraving. Engraved after the painting by John Trumbull. Impression with letters. Condition perfect. Margin $3 / 4$ to $1 / 2$ inches all around.

On the back of the picture (when it was framed) was written the following note by Mr. Purdy,-“Very fine impression, quite as good as a proof, late in the possession of the Trumbull family. Very rare. Dec. 16, '74.--J. H. P.”

\section{ELEANOR GWYN}

Born about 1650; died about 1690. An English actress and celebrated beauty; after she had achieved success as an actress, she became the mistress of Charles II. 'The subject of Peter Cunningham's "The Story of Nell Gwyn."

On account of the great interest in portraits of Nell Gwyn, it has been thought best to list the same, under this heading, rather than distribute them under the various engravers.

\section{NELL GWYN}

167. Nell Gwynne. Mezzotint.

Smith, No. 6.

Engraved by Peter Van Bleeck after the painting by Sir Peter Lely. Only state. Good impression. Surface and condition perfect. Margin $1 / 4$ to $1 / 2$ inch all around. RARE.

"This print is probably from a genuine picture of the personage, although it is different from any of the contemporary prints. The attitude has some resemblance in parts to Lady Mooreland and Catherine Sidley."-J. c. sмiтн.

\section{NELL GWYN}

168. Nell Gwyn. Mezzotint.

\section{Smith, No. 19.}

Published by R. Tompson. Fine impression, with inscription. Surface and condition fair. Mended spot in lower left corner. Cut on the plate-line. Together with 


\section{First Session, Tuesday Evening, A pril 10th}

[No. 168-Continued]

a modern reproduction of the same subject.

The inscription reads as follows:

"Had Paris seen her he had changed his suit And for this Hellen given the Golden fruit

The Subjects' wishes and the Sovereign's Joy

Who burns with better flames our second Troy.

Witt, beauty; goodness, and good humor too

Are more than any Venus else can shew."

Together, 2 pieces.

\section{NELL GWYN}

169. Madame Elleen Gwinn with Her Sons. Mezzotint.

Smith, No. 20.

Published by R. Tompson after the painting by Sir Peter Lely. Second state, with inscription. Fine impression. Surface and condition good. Margin 1/16 inch all around. RARE.

\section{NELL GWYN}

170. Nell Gwyn. Mezzotint.

Smith, Page 1657, No. 50.

Engraved by an unknown artist, similar to Tompson (Smith No. 19) but with dress on, and vase to right. Only state. Fine impression. Surface and condition perfect.

\section{NELL GWYN}

171. Eleanor Gwrnce. Stipple Engraving.

Engraved by John Ogborne after the painting by Sir Peter Lely. Splendid impression with letters. Condition very good. Cut just inside the plate-line. Verr FINE AND RARE. 
First Session, Tuesday Erening, A pril 10th

NELL GWYN

172. Nell Gwrnne, Her Two Sons axd Charles II. Mezzotint.

Not in Smith.

Engraved by Jan Verkolje after his own design. Good impression. Surface and condition fair. Several minor folds. Margin 1/16 inch all around.

\section{NELL GWYN}

173. Madam Gwin. Engraving.

Engraved by G. Valck after the painting by Sir Peter Lely. Fine impression with the inscription. Condition very good. Margin $1 / 8$ inch all around.

The inscription reads as follows,-

"The Sculptors part is done the feature's hitt of Madam Gwin, no Arte can shew her Witt."

\section{NELL GWYN}

174. Madam Elinora Gwrnne. Mezzotint.

Engraved by A. de Blois after the painting by Sir Peter Lely. Good impression with letters. Surface and condition fair. Margin $1 / 4$ inch all around.

From the Tiffin collection.

\section{NELL GWYN}

175. Madam Elinora Gwinne. Mezzotint.

Engraved by Gerard Valck, after the painting by Sir Peter Lely. Splendid impression with letters. Surface and condition perfect. Full margins.

\section{NELL GWYN}

176. Madam Elinora Gwynne. Engraving.

Engraved by Gerard Valck after the painting by $\mathbf{S}$.

Couper. Fine impression in perfect condition. Cut on the plate-line. RarE. 


\section{First Session, Tuesday Evening, April 10th}

\section{NELL GWYN}

17\%. Charles and James Beauclaire (Children of Nell Gwyn). Engraving.

Engraved by Robert White. Brilliant Impression with letters. Condition perfect. Cut on the plate-line.

From the collection of $\mathbf{F}$. Walker.

\section{NELL GWYN}

178. Maday Gwin. Engraving.

Contemporary engraving in a rather crude style by an unknown artist. Good impression in good condition. Cut on the plate-mark. Extremely rare.

\section{NELL GWYN}

179. Eleanor Gwynn. Mezzotint.

Smith, No. 60.

Engraved by Valentine Green after the painting by Sir Peter Lely. Second state, with inscription. Fine ImPressior. Surface fair. Condition good. Margin 1/4 inch all around.

\section{NELL GWYN}

180. Lady with Lamb. Mezzotint.

Smith, No. 191.

Engraved by James McArdell after the painting by Sir

Peter Lely. Second state. Good impression. Surface and condition fair. Slight mended tear on the margin. From an unidentified collection.

"Mentioned by Granger and Bromley as a portrait of Nell Gwynn, but it does not at all resemble her."-J. c. smitr.

\section{NELL GWYN}

181. Nell Gwrx and Charles II. Mezzotint.

Engraved by an unknown artist. Fair impression. Surface and condition good. Cut on the plate-line. 


\section{JOHN OGBORNE}

Born at London 1725; died in 1795. He was a scholar of Bartolozzi's, and engraved in the dotted manner. Several of the large plates for Boydell's "Shakespeare Galleries" are among his best work. In his later plates, line is combined with stipple.

OGBORNE, JOHN

182. Mrs. Jordan in the Character of the Romp. Stipple Engraving.

Engraved after the painting by George Romney. First state, with the word Romp in place of Country Girl. Splendid impression. Perfect condition. Cut just outside the plate-line. Very rare and fine.

\section{[See Reproduction $]$}

\section{DANIEL ORME}

Engraver and miniature painter. He worked about 1800 and exhibited many portraits in miniature at the "Royal Academy," between 1797 and 1801. He engraved in stipple many portraits of persons celebrated at the time.

ORME, DANIEL

183. Peasant Life. Stipple Engraving.

Five engravings of English peasant life. Colored BY hand. Fine condtion.

Framed.

\section{SAMUEL PALMER}

English watercolor painter and etcher. Born in 1805; died at Reigate in 1881.

"His romantic idealism not worthily carried on the sentiment which inspired much of Blake and all of Calvert."-A. м. HIND.

PALMER, SAMUEL

184. The Morning of Life. Etching.

Hardie, No. 10.

Signed on plate,-“S. Palmer.” Lettered impression, on India paper with full margins. Published by "The English Etching Club." 


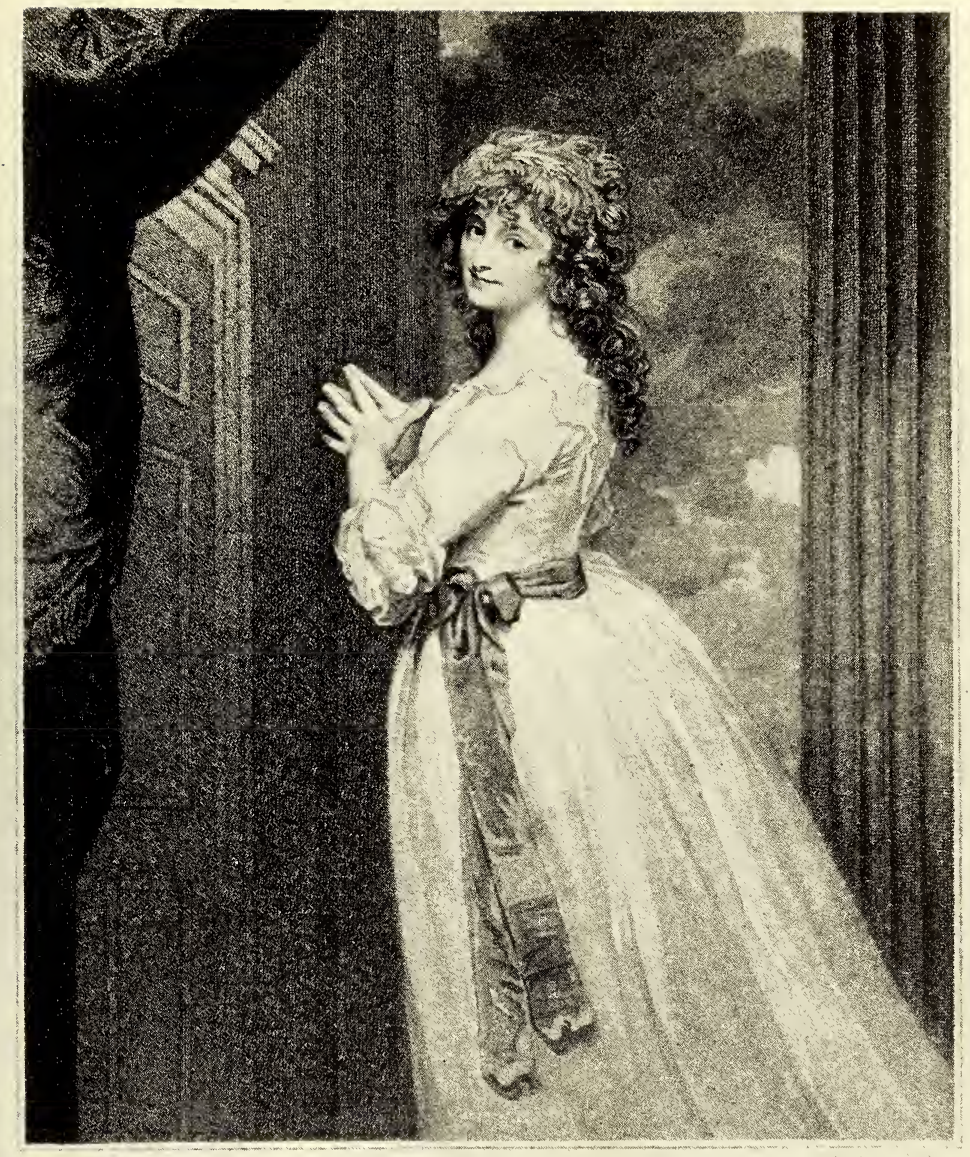

JOHN OGBORNE. STIPPLE ENGRAIING

Mrs. Jordan in the Character of the Romp

[No. 182] 


\section{WILLIAM PE'THER}

Born at Carlisle, 1731; died, 1795. Painted portraits and miniatures; studied mezzotinting and attained great excellence.

\section{PETHER, WILLIAM}

185. Man Smoking. Mezzotint.

Not in Smith.

Engraved after the painting by Metsu. Stippled Letter proof before title. Very fiNe impression. Surface nearly perfect, mended tear in upper margin and slight printing crack on the side. Margin $1 / 2$ inch all around.

[Also, by another engraver.]

Man in Hat and Cloak. Mezzotint.

Engraved by an unknown engraver, probably of the Dutch school. Proof before all Letters. Brilliant impressiox in perfect condition.

Together, 2 pieces.

\section{JOHANN THEOPHILUS PRES'TEL}

German painter and engraver. Born in Swabia, 1739; died at Frankfort, 1808. He travelled in Italy and then settled at Nüremberg where he married the engraver Maria Catharina Holl, who assisted him on some of his best plates.

\section{PRESTEL, JOHANN THEOPHILUS}

186. Allegory. Woodcut.

Chiaroscuro woodcut engraved on two blocks after the design by Cigoze(?) Proof before all Letters. Splendid impression in perfect condition. Cut outside the plate-mark. 


\section{MARC AN'TONIO RAIMONDI}

Born in Bologna about 1480; died there about 1530. Started work in the atelier of Francesco Francia. About 1505, he came under the strong influence of Diirer. From 1509 to 1510 , he seems to have been much under the influence of Lucas van Lyden. Shortly after going to Rome, he entered the studio of Raphael, with whose name his own is associated most closely in the history of engraving.

\section{RAIMONDI, MARC ANTONIO}

18\%. Alexander Placing Homer's Work in the Tomb of Darius. Engraving.

Bartsch, No. $20 \%$.

Engraved after the design of Raphael. Superb impression in practically perfect condition. Several thin spots and minor folds. Margin $1 / 4$ inch all around. VERY FINE.

"This print is one of the most perfect that Marc Antonio engraved after Raphael."-BARTSCH.

\section{RAIMONDI, MARC ANTONIO}

188. Cupids Dancing. Engraving.

Bartsch, No. $21 \%$.

Engraved after the design by Raphael. Signed on the plate,- “M. $A . F . "$ Splendid inipression with plateuine intact. A few thin places, otherwise in perfect condition. Extremely rare.

From the P. Gellatly collection.

\section{RAIMONDI, MARC ANTONIO}

189. Mount Parnassus. Engraving.

Bartsch, No. $24 \%$.

Signed on the plate with the monogram,-“M. A. F." Engraved after Raphael's fresco. VERY FINe CLEAR IMIpression in unusually good condition. A few small folds and mended spots. Very fine and rare.

"Raphael painted this subject in the palace of the Vatican, but this engraving was made from a drawing differing in several respects from the painting. It is one of the most beautiful of Marc Antonio's engravings and also one of the best known."-BARTsch. 


\section{RAIMONDI, MARC ANTONIO}

190. Venus et l'Amour. Engraving.

Bartsch, No. 311.

Engraved probably after a drawing by Raphael. SplenDID EARLY IMPRESSION in very good condition. Margin $1 / 4$ inch all around. One slight mended spot.

With two unidentified collectors' marks.

"This print is one of the best things that Marc Antonio has engraved after a drawing which is believed to be the work of Raphael." - BARTSCH.

\section{RAIMONDI, MARC ANTONIO}

191. La Sibylle. Engraving.

Engraved by an unknown engraver of the school of Marc Antonio. Splendid impression in practically perfect condition. One very slight thin place.

From the collections of Pierre Mariette 1704, Willets 1812, Sir Mark Sykes, and Mary Jane Morgan.

\section{PAUL RAJON}

Born at Dijon, 1844; died in Paris, 1888.

"He studied etching under Gaucherel and Flameng, and at the Salon of 1869 received a medal. In the following year, and again in 1875, he received medals for his etchings; and at the Universal Exposition of 1878, he was placed Hors Concours for his masterly portrait of Darwin."-H. BERALDI.

RAJON, PAUL

192. La Querelle Apaisée. Etching.

Beraldi, No. 19.

Etched after the painting by B. Vautier. Signed artist's PROOF. SPLENDID IMPRESSION IN PERFECT CONDITION.

RAJON, PAUL

193. Lady Crewe. Etching.

Beraldi, No. 100.

Etched after the painting by Humphrey. Signed artist's PROof. SPLENDId IMPRESSION IN PERFECT CONDITION. Extremely fine.

This plate was highly praised by Beraldi. 
RAJON, PAUL

194. Head of a Young Girl. Etching.

Signed ARtist's proof, printed in reddish ink on brownish paper. IN PERFECT CONDITION AND WITH FULL MARGINs.

A charming composition.

\section{REMBRAND'T VAN RIJN}

Celebrated Dutch painter and etcher. Born at Seyden in 1607; died at Amsterdam in 1669. Pupil of Swanenburch and Lastman, but largely self-taught.

"The opinion among etchers which enthrones Rembrandt as King of his craft is the most recent instance of perfect unanimity among people of all nationalities. As we all say that Phidias was the greatest sculptor, Homer the greatest epic poet, and Shakespeare, the greatest dramatist, so we are all agreed on the world wide supremacy of Rembrandt. In his own lines of work there is no one in all history to be compared with Rembrandt."-P. G. HAMERTON.

"The whole of Rembrandt is in his engraving-his mind, tendencies, imagination, reverie, good sense, chimeras, difficulties of rendering the impossible, realities in nothingness. It is the same craftsmanship, the same set purpose, the same carelessness and insistence, the same strangeness of style, the same desperate and sudden success achieved by expression."EUGÈNE FROMENTIN.

\section{REMBRANDT VAN RIJN}

195. Rembrandt and Saskia. Etching.

Bartsch, No. 19.

Signed on the plate,-“Rembrandt f. 1636." SEcond sтAтE, after the removal of the slipped-stroke over Saskia's right eyebrow. Fine impressions and in PERFECT Condition, with small margins.

From the Galichon and John Webster Collections.

\section{REMBRANDT VAN RIJN}

196. Rembrandt and Saskia. Etching.

Bartsch, No. 19.

Signed on the plate,-“Rembrandt f. 1636." SEcond state. Modern impression. Fair condition. Cut outside plate-mark all around. 
First Session, Tuesday Evening, A pril 10th

\section{REMBRANDT VAN RIJN}

19\%. The Triumph of Mordecai. Etching.

Bartsch, No. 40.

Unsigned. Etched about 1640. Only state. Splendid IMPRESSION WITH BURR. IN PERFECT CONDITION, with $1 / 8$ inch margin all around. A few small printer's hair-line folds, and a small skillfully mended spot near the top. Fine and rare.

"First dry-point, then finished with delicate biting; then strongly accented with dry-point. A delightful illustration of the story. Note the subtlety with which light and shadow are interchanged and yet kept broad, and how all the curves center in Mordecai's figure."c. J. Hownes, - "Notes on the Art of Rembrandt."

\section{REMBRANDT VAN RIJN}

198. Christ and the Tribute Money. Etching.

Bartsch, No. 68.

Unsigned. Etched about 1634. Second state. Good impression with small margin.

From the J. Peoli and Ambrose Firmin-Didot Collections.

\section{REMBRANDT VAN RIJN}

199. A View of Amsterdan. Etching.

Bartsch, No. 210.

Unsigned. Etched about 1640 or earlier. Fine IMPression on paper water-marked with a coat of arms and two lions. Margin 1/16 inch on top and side, cut on the plate-mark below. Ix perfect condition. The quality and immaculate condition of the paper adds greatly to the beauty of the impression. RARE.

From the De Paar and Ambrose Firmin-Didot Collections. 


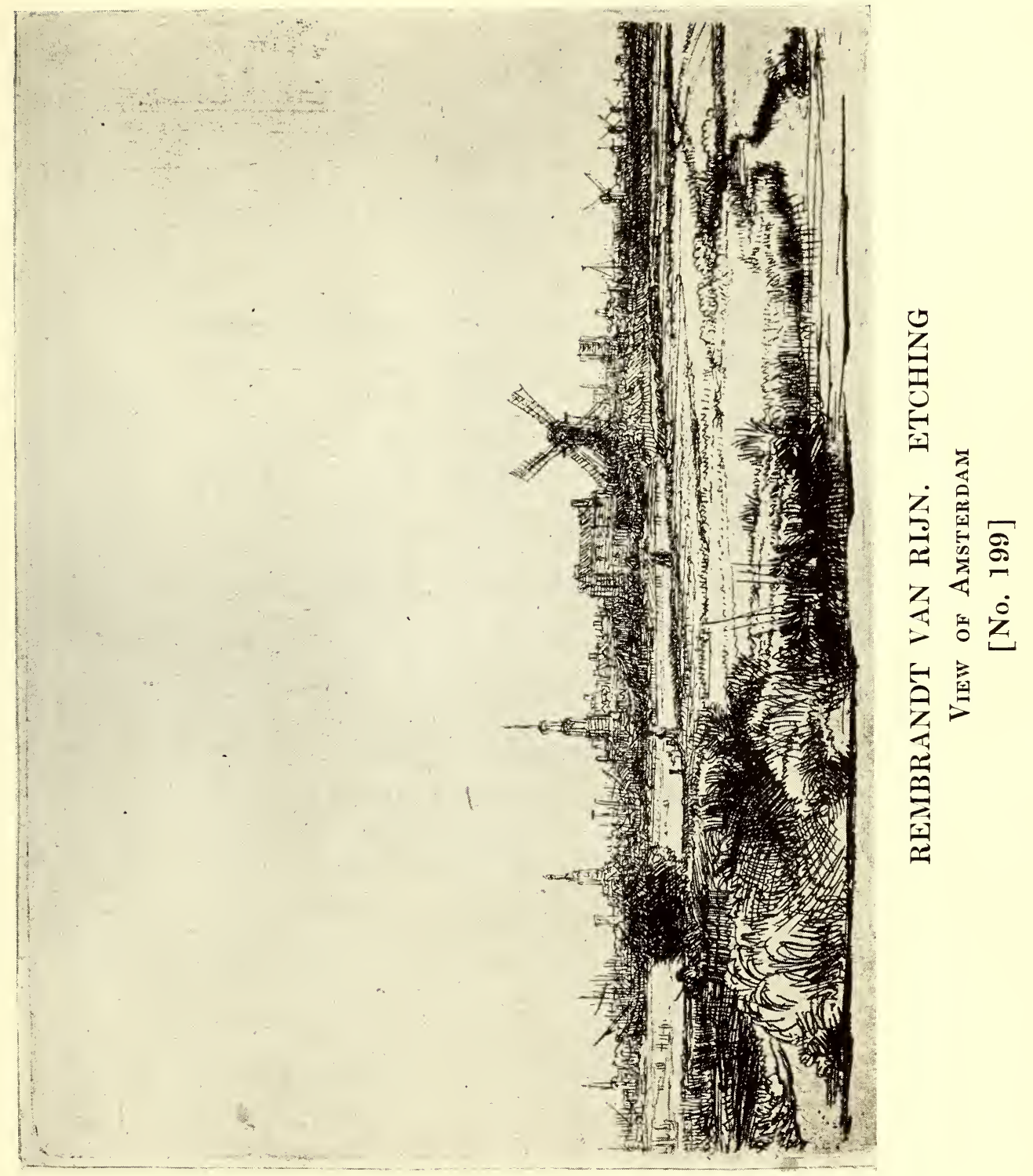





\section{At The American Art Galleries MADISON SQUARE SOUTH, NEW YORK \\ UNRESTRICTED PUBLIC SALE BY ORDER OF ALBERT W. PROSS, ESQ., AND THE NEW YORK TRUST COMPANY, AS EXECUTORS \\ Second Session, Numbers 200 to 302, inclusive}

WE DNESDAY EVENING, APRIL 11th, AT 8:00 O'CLOCK

\section{SAMUEL WILLIAM REYNOLDS}

Born in England, 1773; died at Bayswater, 1835. Pupil of C. H. Hodges.

\section{REYNOLDS, SAMUEL WILLIAM}

200. Garrick in the Character of Abel Drugger. Mezzotint. Whitman, No. 98.

Engraved after the painting by J. Zoffany. First state, before title and with the error in the artists' names, the name Sir Joshua Reynolds being pasted over by a slip containing the name "J. Zoffany." Splendid impression. Surface and condition good. Margin $1 / 4$ inch all around.

\section{REYNOLDS, SAMUEL WILLIAM}

201. Chapeau de Paille. Mezzotint.

Whitman, No. 442.

Engraved after the painting by Rubens. Fourth state. Good impression. Surface and condition fair. Mounted down. Margin 1 inch all around.

There is a manuscript note on an impression of this plate to the effect that "this Print was chiefly engraved by Coussins." 


\section{ALEXANDER HAY RITCHIE}

Scotch-American engraver. Born at Glasgow in 1822. He emigrated to America where he practiced his craft in line and mezzotint.

RITCHIE, ALEXANDER HAY

202. Jyo. Williams, Fourth Bishop of Connecticut. Engraving.

Mixed engraving after the painting by D. Huntington. Good impression with inscription. Signed in pencil by both painter and engraver. On India paper with full margin.

\section{CHRIS'TOFANO ROBE'T'TA}

Born in Florence, 1463, and worked until 1522.

"The prints signed with his name merit special attention. Drawn with unerring beauty and elegance, and engraved with a boldness and ease rare amongst the early Italians, they may sometimes be marred by timidity and inexperience, never by want of taste nor incorrectness of design."DUPLESSIS.

\section{ROBETTA, CHRISTOFANO}

203. The Adoration of the Magi. Engraving.

Bartsch, No. 6.

Signed at the plate,-_-“Robetta." Fine impression, slightly gray in places on heavy paper water-marked, "M within a shield." Folded across middle and with one or two slight thin spots, condition otherwise unusually fine. Margin 1/16 inch all around. RARE.

\section{THOMAS ROWLANDSON}

English artist. Noted as a caricaturist. Born in London, 1756; died in 1827.

Among his plates are the celebrated "Dr. Syntax" engravings.

\section{ROWLANDSON, THOMAS}

204. The Beau and the Belle. Drawing.

Original drawing with pen and watercolor wash. Signed, - "Rowlandson." 


\section{EGIDIUS SADELER}

Dutch engraver, born at Antwerp in 1575. He went to the court of Austria and worked in Prague, where he died in 1629.

\section{SADELER, EGIDIUS}

205. Head of ax Old Max. Engraving.

Engraved after the design by Albrecht Dürer. Good impression with letters. Is PERFECT CONDition and with $1 / 4$ inch margin all around.

\section{JOSEPH SAUNDERS}

English mezzotint engraver, flourished in London about 17\%2-1797.

\section{SAUNDERS, JOSEPH}

206. David Garrick as Steward of the Stratford Jubilee, 1769. Mezzotint.

Smith, No. 4 .

Engraved after the painting by B. Van der Gucht. SEcond state, with inscription. Good impression. Surface fair. Condition good. Cut on the plate-line.

\section{PE'TER SCHENK}

Painter, etcher, mezzotinter, and art publisher. Born at Elberfeld, 1645; worked at Amsterdam, where he died in 1715 .

\section{SCHENK, PETER}

20\%. The Prodigal Sox. Mezzotint.

Andresen, No. 1t.

Engraved after the painting by Geraers. Very fINE Impression. Surface and condition perfect. Margin $1 / 16$ inch all around. 


\title{
WILLIAM SHERWIN
}

Born in Wellington, Shropshire, about 1650, and flourished from 1670 to 1711 ; died about 1715 .

\section{SHERWIN, WILLIAM}

208. Daniel Defoe. Engraving.

Good impression with the inscription. IN PERFECT CONDition. Cut on the plate-mark.

The inscription reads as follows,-

"Here you may see an Honest Face. Arm'd Against Envy and Disgrace, Who Lives Respected still in Spite Of Those that Punish them yt. Write."

\section{JOHN SIMON}

\begin{abstract}
"The engraver who must be considered as almost the rival of John Smith was John Simon, who was born in Normandy about 1765, and after practicing line engraving at Paris, came to London as a refugee in the early years of the century. Upon reaching this country he seems to have devoted himself exclusively to mezzotint, and with such success that ere long he had gained a complete mastery over its technicalities. He contended with John Smith for premier position, and when the latter disagreed with Kneller, Simon succeeded him and engraved over forty plates from Kneller's pictures."-A. wirmman,-"Masters of Mezzotint."
\end{abstract}

SIMON, JOHN

209. Philip, Earl of Chesterfield. Mezzotint.

Smith, No. 38.

Engraved after the painting by W. Hoare. SEcond state, with letters. Fine impression. Surface good. Condition perfect. Margin $1 / 2$ inch all around.

A fine portrait of the celebrated author of the "Letters."

\section{SIMON, JOHN}

210. John Milton. Mezzotint.

Smith, No. 104.

Engraved after the painting by R. White. First state, before the change in the address. Fine impression. Surface and condition very good. A slight mended tear and a partial erasure in the inscription. Margin $1 / 4$ inch all around.

From the collection of Queen Victoria of England. 
Second Session, Wednesday Evening, April 11th

SIMON, JOHN

211. Sir Isaac Newton. Mezzotint.

Smith, No. 109.

Engraved after the painting by Sir Godfrey Kneller. Only state. Good impression. Surface and condition fair. Cut on the plate-mark.

SIMON, JOHN

212. Mrs. Anne Oldfield. Mezzotint.

Smith, No. 113.

Engraved after the painting by I. Richardson. THIRD state, before entire inscription was changed. Condition and surface good, a few slight mended tears. Cut just outside the plate-mark.

\section{SIMON, JOHN}

213. Alexander Pope. Mezzotint.

Smith, No. 125.

Engraved after the painting by M. Dahl. IndeTERMinate state. Lower margin trimmed $3 / 16$ inch inside lower plate-mark, thereby cutting off space where there may or may not have been an address. Surface and condition fair. Two cross folds.

\section{SIMON, JOHN}

214. Mathew Prior. Mezzotint.

Smith, No. $12 \%$.

Engraved after the painting by I. Richardson. First state, before Richardson's address. SPLENdid Impression. Surface and condition practically perfect. Margin 1/16 inch all around.

The best portrait of the poet. 


\section{JOHN SMITH}

Born, 1652; died, 1742 .

"Even in his own time the merits of this engraver were highly appreciated, and subsequent writers, as Walpole, have considered him one of the great improvers of art. He certainly excelled in brilliancy of effect, and was powerful, clear and correct in drawing."-chaloner smith.

SMITH, JOHN

215. Willian Congreve. Mezzotint.

Smith, No. 54.

Engraved after the painting by Sir Godfrey Kneller. Third state. Fair impression. Surface and condition very good. Margin $1 / 8$ inch all around.

"Born near Leeds, 1669. educated in Ireland; wrote many plays, amongst them, the Double Dealer, Mourning Bride, and Way of the World. His carriage was upset in the summer of 1728 at Bath, and this is supposed to have accelerated his death in January, 1729."J. c. SMITH.

\section{SMITH, JOHN}

216. Mary Beatrix, Queex of James II. Mezzotint. Smith, No. 171.

Engraved after the painting by $\mathrm{N}$. de Largillière. Finst state, before the modern imprint. Clear impression. Surface and condition perfect. Margin $1 / 4$ inch all around.

\section{SMITH, JOHN}

217. James, Duke of Ormond. Mezzotint.

Smith, No. 194.

Engraved after the painting by Sir Godfrey Kneller. Only state. Very fine impression. Surface and condition perfect. Margin $1 / 8$ inch all around.

\section{SMITH, JOHN}

218. Thomas, Earl of Penbroke. Mezzotint.

Smith, No. 198.

Engraved after the painting by W. Wissing. Secord state, before the modern imprint. Fine, Clear impression. Surface and condition perfect. Margin $1 / 4$ inch all around. 


\section{Second Session, Wednesday Evening, A pril 11th}

SMITH, JOHN

219. Alexander Pope. Mezzotint.

Smith, No. 203.

Engraved after the painting by Sir Godfrey Kneller.

Third state. Surface and condition perfect. Margin

1 to $1 \frac{1}{2}$ inches all around.

SMITH, JOHN

220. Richard Steele. Mezzotint.

Smith, No. 244.

Engraved after the painting by J. Richardson. Good Impression. Surface and condition very good. Margin $1 / 4$ to $3 / 4$ inch all around.

\section{SMITH, JOHN}

221. William Wycherley. Mezzotint.

Smith, No. 284.

Engraved after the painting by Sir Peter Lely. SEcond state, with inscription. Fine impression. Surface and condition perfect. Margin 1/16 inch all around.

This portrait, though painted when Wycherley was 28 years old, was prefixed to a volume of his poems published in his 64th year. The quotation from Virgil pathetically alluded to the difference between his appearance at the time this picture was painted and that at the period of the publication of the book.

\section{JOHN RAPHAEL SMITH}

Born at Derby, 1752; died at Doncaster, 1812.

"A very considerable number of his prints are from his own designs and pictures. . . The prints published by him between the years 1775 and 1787, are, nearly without exception, amongst the most admirable productions ever executed in mezzotint."-CHALONER sMrTH.

"Among all the engravers the art of mezzotint has produced, J. R. Smith is perhaps the most skilful and accomplished."-ALERED WHituan.

SMITH, JOHN RAPHAEL

222. Miss Carter. Mezzotint.

Smith, No. 34.

Engraved after the artist's own design. Undescribed state, with the address of Wm. Humphrey only. Goon mpression. Fine surface and condition. Margin 1/4 inch all around. 


\section{SMITH, JOHN RAPHAEL}

223. Flirtilla. Stipple Engraving.

Stippled engraving after the artist's own design. STIPPLED LETTER PROOF. VERY FINE IMPRESSION IN PERFECT condition. Cut just inside the plate-line all around. A charming subject.

\section{WILLIAM SMI'TH}

English etcher and engraver, flourished, perhaps, at London about 1824.

\section{SMITH, WILLIAM}

224. John Gay. Etching.

Smith, No. 1.

Engraved after the painting by Zinck. First state, scratched letter proof. Splendid impression. Surface and condition practically perfect. One or two slight pinpricks. Margin $1 / 8$ inch all around.

"Born near Barnstaple in 1688 apprenticed to a silk mercer in London, but quitted this employment, became known to Swift, Pope, and other literary persons, and devoted himself to poetry. In 1727 his famous "Beggar's Opera" met with the greatest success. He was patronized by the Duke and Duchess of Queensbury. He died in 1732, and was buried in Westminster Abbey."-J. c. sмiтh.

\section{SIR ROBER'T S'TRANGE}

Born in one of the Orkney Islands, 1723; died at London, 1792.

"Strange has a style of his own-rich and peculiarly adapted to the rendering of flesh tints."-THE GOLDEN AGE OF ENGRAving.

\section{STRANGE, SIR ROBERT}

225. The Children of Charles I. Engraving.

Engraved after the painting by Sir Anthony Van Dyck.

Regular impression with inscription. Margins intact.

Philip, Earl of Pembroke. Engraving.

Engraved by Peter Lombart after the painting by Sir Anthony Van Dyck. Impression with letters. Condition good. One or two pin-pricks. Margin 1/16 inch all around.

Together, 2 pieces. 


\section{JACQUES JOSEPH TISSO'T}

French painter and etcher. Born at Nantes in 1836. Lived for many years at London.

"Son oeuvre, un des plus importants de la gravure originale dans ces vingt dernières années."-BERALDI.

\section{TISSOT, JACQUES JOSEPH}

226. Miss N., or La Frileuse. Etching.

Beraldi, No. 19.

Proof on Holland Paper, signed and stamped by the artist. Fine impression in perfect condition. Original margins. Mounted down for framing.

Mavourneen. Etching.

Beraldi, No. 24.

Proof on Holland Paper, signed and stamped by the artist. Fine impression in perfect condition. Margin $2 \frac{1}{2}$ inches all around. Mounted down for framing. "Maitresse point-seche; morceau capital de l'oeuvre.'BERALDI.

The Portico of the National Gallery. Etching.

Beraldi, No. 32.

Proof on Holland Paper, signed and stamped by the artist. Fine impression in perfect conditon. Original margins.

Together, 3 pieces.

\section{P. W. TOMKINS}

"P. W. Tomkins (1760-1840), also the Queen's engraver, was, perhaps, the most gifted and refined exponent of Bartolozzi's method, but his originality proclaimed itself and his art had its individual charm. Bartolozzi himself generously said of him: 'He is my son in the art, he can do all I can in this way and I hope he will do more.' Contemporary life and art found him readily responsive, and his domestic and idyllic prints have extended their appeal from his own day to this."-M. c. salaman, - "Old Engravers of England."

TOMKINS, P. W.

22\%. Musidora. Engraving.

Stipple and his engraving after W. Hamilton. Printed IN COLOR and retouched largeley by hand. Lettered impression. Condition perfect. Ample margin. 


\section{Second Session, Wednesday Evening, A pril 11th}

TOMKINS, P. W.

228. Sкатing. Stipple Engraving.

Stipple engraving in color after the design by Hamilton. Touched up in color by hand. Good impression in perfect condition.

Cupids Around a Bonfire.

Stipple engraving, touched in color.

Framed.

Together, 2 pieces.

\section{CHARLES TURNER}

Charles Turner, one of the most eminent English engravers, was born at Woodstock in 1773. He entered the "Academy" in 1795 and at first worked for Boydell in Bartolozzi's style. Afterwards he turned his attention to mezzotint. He was particularly successful as an interpreter of the painter, Turner, for whom he engraved twenty-three numbers of the Liber Studiorum. In 1828, having already been appointed mezzotint engraver in ordinary to the King, he was elected associate engraver of the Royal Academy. He died in London in 1857.

\section{TURNER, CHARLES}

229. London from Greenwich. Mezzotint.

Rawlinson, No. 26.

Engraved in mezzotint by Charles Turner over THE original etching by J. M. W. Turner. First state. SplenDID IMPRESsion. Surface and condition perfect. With original margins.

"I have already alluded to this distant view of London delightful alike in Mr. Fawkes' brown picture and in the print which is taken with little alteration from it. In both we are attracted by the pleasant knolls and grassy slopes of the park in front, by the gleaming reaches of river beyond with white sails dotted all about, and by the fine rendering of the great city on the horizon, its very smoke made to enhance its beauty."-w. G. RAwLINSox.

\section{TURNER, CHARLES}

230. Washington Irving. Mezzotint.

Whitman, No. 275.

Engraved after the painting by G. Stuart Newton. UNdescribed trial proof before the first state. Proof Before all letters. Brilliant impression. Surface and condition good. Plate lines strengthened. Margin 1 to 2 inches all around. 
Second Session, Wednesday Evening, A pril 11th

\section{TURNER, CHARLES}

231. Charles I. as Prince. Mezzotint.

Whitman, No. $\$ 70$.

Engraved after the painting by Delaram. First state.

Proof before all Letters. Very fine impression.

Surface and condition perfect. Margin $1 / 4$ to 1 inch all around.

\section{UNKNOWN ENGRAVERS}

\section{UNKNOWN ENGRAVER}

232. Mrs. Clive as Phillida. Mezzotint.

Smith, No. 19 (page 1682).

Exgrayer's proof before all letters. Superb imPression. Perfect surface and condition. Margin 1/4 inch all around. Unique print; Chaloner Smith mentions but one known impression, and that one clipped.

"The workmanship of this print is admirable, the style of Van Bleeck has some slight resemblance to it."-J. chaloner smitr.

\section{[See Reproduction]}

\section{UNKNOWN ENGRAVER}

233. Oliver Cromwell. Mezzotint.

Smith, page 1684, No. 26.

Engraved after the painting by Sir Peter Lely. Finst state, before the change of address. VERY FINE Impression. Surface and condition very good. Cut on the plate-line and margin reinforced. Extremely rare. Only three impressions of this state known.

"The execution of this plate is much superior in delicacy and effect to the prints engraved by J. Sympson, but possibly it may have been done by him."-J. c. smith.

\section{UNKNOWN ENGRAVER}

234. Thomas Otway. Mezzotint.

Smith, page 1668, No. 95.

Engraved after the painting by Sir Peter Lely. SEcond 


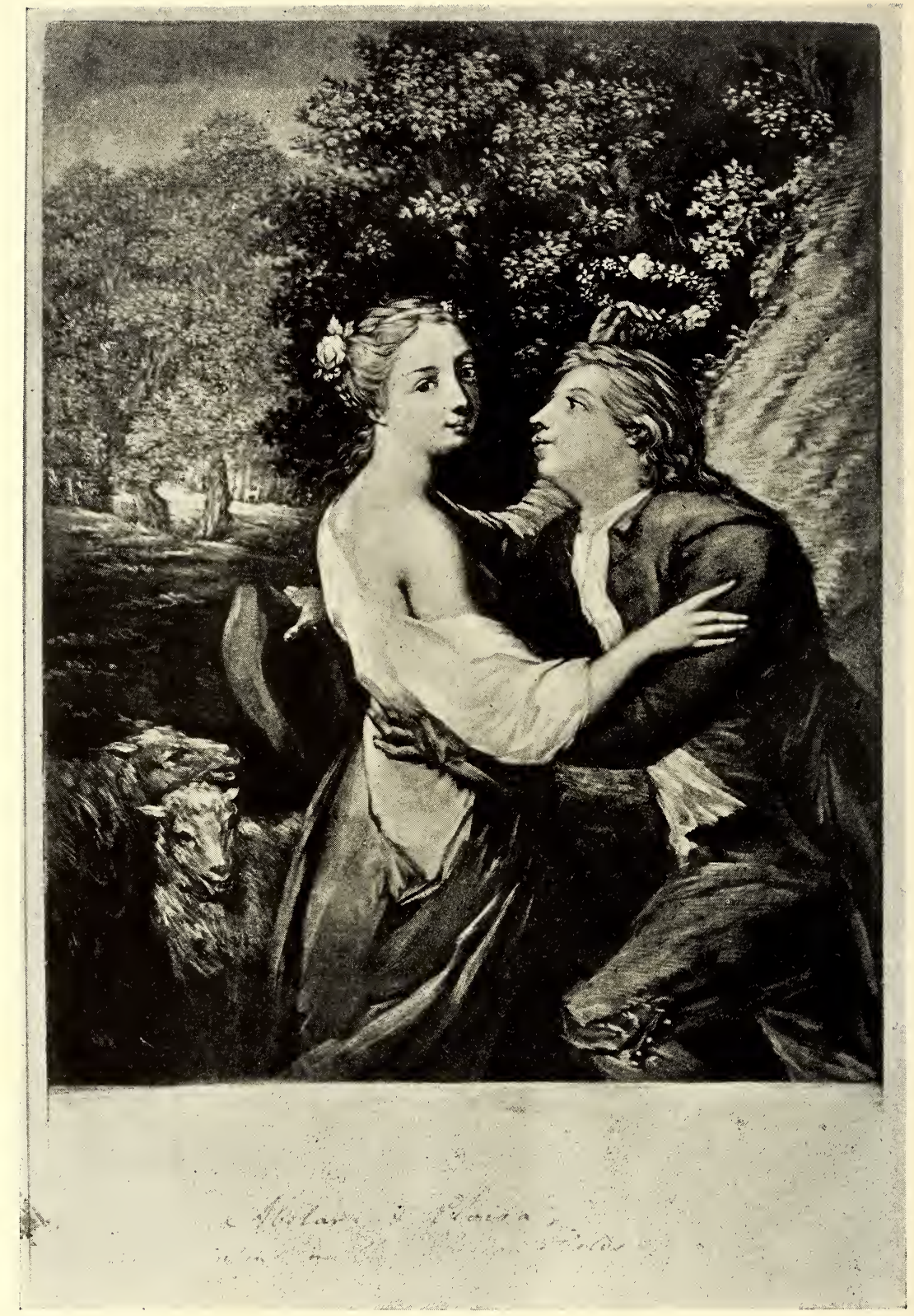

UNKNOWN ENGRAVER. MEZZOTINT

Mrs. Clive as Phillida

[No. 232] 
Second Session, Wednesday Evening, A pril 11th

[No. 234-Continued]

state, before the address was changed. Good impression. Surface and condition fair. New margin added in places.

"Born in Sussex, 16.51; first tried the stage, but not succeeding in it, devoted himself to writing for it; amongst his plays were the great favorites, the Orphan, and Venice Preserved. He died in a very distressed state in 1685."- - c. c. sмrтH.

\section{UNKNOWN ENGRAVER}

235. JANe Shore. Stipple Engraving.

SCratched letter proof before title and artist's name.

Splendid impression, in perfect condition. Margin $1 / 16$ inch all around.

\section{UNKNOWN ENGRAVER}

236. J J S Shore. Mezzotint.

Not in Smith.

Engraved probably by Sir Christopher Wren. Proof, merely with title of personage. Good impression. Condition perfect, except for one small mended spot. ExTREMELY RARE.

\section{UNKNOWN ENGRAVER}

237. Charles I, with Henrietta and Children. Mezzotint. Smith, page 1652, No. 20.

Engraved after the painting by Sir Anthony van Dyck. Only state. Good impression in perfect condition. From the collection of John Barnard.

\section{UNKNOWN ENGRAVER}

238. William Shakespeare. Mezzotint.

Engraved by an unknown artist after the Chandos portrait. Perhaps a copy of the Cousins mezzotint, inasmuch as it is almost the same size. Proof before letters on India paper. Surface and condition perfect. With margins. 
Second Session, Wednesday Evening, A pril 11th

UNKNOWN ENGRAVER

239. Francis Bacon. Engraving.

Engraved by an unknown artist, probably after the print by Simon de Passe. Splendid impression in perfect Condition. Margin $3 / 4$ inch all around. Very fine and RARE.

From the Ambrose Firmin-Didot collection.

\section{UNKNOWN ENGRAVER}

240. Sir Thomas Killigrew. Engraving.

Engraved by an unknown hand, probably in imitation of Abraham Bosse's portrait. Fair impression, in fair condition. The inscription, in twenty-four lines, beginning "Foole that I was who had so faire a State," has a very pointed moral.

\section{UNKNOWN ENGRAVER}

241. Portrait of a German Prince. Engraving.

Unfinished trial proof with the design for the border drawn upon the margin, perhaps by the artist. Engraved by an unknown artist, perhaps Kilian. Fine impression IN PERFECT CONDITION.

From the Ambrose Firmin-Didot and Julian Marshall collections.

\section{UNKNOWN ENGRAVER}

242. Adam and Eve. Engraving.

Proof before all letters. Splendid impression in PERFECT CONDITION.

Framed.

\section{UNKNCWN ENGRAVER}

243. Portrait of a Man. Mezzotint.

Proof before all letters. Fine impression. Surface and condition perfect. Margin $1 / 4$ to 1 inch all around. 
Second Session, Wednesday Evening, A pril 11th

\section{UNKNOWN ENGRAVER}

244. Samuel Butler. Mezzotint.

Not in Smith.

Engraved after the painting by Sir Peter Lely. Pub-

lished by Thos. Bowles. Good impression. Surface and condition fair. Mended printing crack at top. Margin $1 / 4$ to 1 inch all around.

Kitty (Clive) Fleecing the Old Jew. Mezzotint.

Published by Carrington Bowles. Lettered impression.

Fair surface and condition.

Together, 2 pieces.

\section{UNKNOWN ENGRAVER}

245. Thomas, Archbishop of Canterbury. Mezzotint.

Published by E. Cooper. Fair impression, in Perfect condition. Margin $1 / 8$ inch all around.

William Wrcherley. Mezzotint.

Published by John Bowles. Good impression, In PERfect condition. Margin $3 / 4$ inch all around.

Together, 2 pieces.

\section{UNKNOWN ENGRAVER}

246. Rochester and His Mistress. Mezzotint.

Proof before all letters. Very fine impression, in Perfect Condtion. Margin $1 / 4$ inch all around.

The Mouse Trap. Mezzotint.

Engraved by M. Verkolje after the painting by Gerard Douw. Good impression, cut on the plate-line.

Together, 2 pieces.

\section{UNKNOWN ENGRAVER}

24\%. Queen Elizabeth. Engraving.

Published by Paul de la Honne. Very fine impression, in perfect condition. Margin 1/16 inch all around.

Queen Elizabeth. Engraving.

By an unknown artist. Oval, with motto, "Posui Deum adiutorem meum." Fair impression, in good condition. 
[No. 247-Continued]

Queen Eluzabeth in Parliamente Engraving.

Fine impression, with inscription.

Together, 3 pieces.

\section{UNKNOWN ENGRAVER}

248. Robert Devereux, Earl of Essex. Engraving.

Published by Compton Holland. Good impression, with inscription. Condition perfect. Margin $1 / 4$ inch all around.

From the John Young Collection.

Arbella Stewart. Engraving.

Engraved by I. W. Set. Good impression, with inscription. Condition perfect. Cut outside plate-line. Together, 2 pieces.

\section{WALLERAN'T VAILLAN'T}

Dutch engraver. Born at Lille in 1623; died at Amsterdam, 1677. He was the friend and plate printer of Prince Rupert, reputed inventor of the process of mezzotint, and he was one of the first to work in the medium. Vaillant was one of the first to practice the new art of mezzotint engraving.

\section{VAILLANT, WALLERANT}

249. Reading a Letter. Mezzotint.

Wessely, No. 183.

Engraved after the painting by Gerars. Undescribed first state, before the engraver's name. Good impression. Fair surface. Perfect condition. Cut just outside the plate-mark. Fine and rare.

\section{VAILLANT, WALLERANT}

250. Charles II. When a Boy. Mezzotint.

Signed on the plate,- “ $W$. Vaillant fec. eb exc." Fine impression. Surface good. Condition perfect. Cut just outside the plate-mark. 


\section{GERARD VALCK}

Dutch engraver. Born at Amsterdam about 1626; died there, 1720. He was first a servant to Blooteling, but having married his master's sister, was instructed in engraving, and taken into partnership.

\section{VALCK, GERARD}

251. William III. of Orange. Engraving.

Signed on the plate,-_"Gravé par Gerard Valck." Рвоон before title. SPlendid impression in practically perfect condition. Cut on plate-line.

\section{VALCK, GERARD}

252. Ortance Manchini, Duchess of Mazarin. Engraving. Engraved after the painting by Sir Peter Lely. Signed on the plate,-“G. Valck sculp. et excud. 1678." Fine impression in perfect condition. Cut on the plate-line and remargined.

\section{VALCK, GERARD}

253. Ortance Manchini, Duchess of Mazarin. Engraving. Engraved after the painting by Sir Peter Lely. Proof before all Letters. Superb impression in perfect condition. Margin $1 / 16$ inch all around.

From the collection of Alfred Hubert and another unknown to Fagan.

\section{PIETER VAN BLEECK}

Dutch painter and engraver, son of a portrait painter, was at the Hague in 1695 . He went to London in 1723, where he was much employed, and died there in $\mathbf{1 7 6 4 .}$

\section{VAN BLEECK, PIETER}

254. Portrait of a Man in Dark Cloak and Hat. Mezzotint. Not in Smith.

Proof before all Letters. Rich impression in PerFECT Condition except for one small thin spot. Margin $1 / 8$ inch all around. 
Second Session, Wednesday Evening, A pril 11th

\section{CORNELIS VAN DALEN}

Engraver at Antwerp. Born about 1620. Pupil of his father and Cornelis Visscher.

\section{VAN DALEN, CORNELIS}

255. Pietro Aretino. Engraving.

Andresen, No. 8.

Engraved after the painting by Titian. First state, PROOF beFore all Letters. SPlendid impression IN Perfect condition. Margin one inch all around. Very FINE.

VAN DALEN, CORNELIS

256. Giorgio Barbarello (Giorgione da Castelfanco). Engraving.

Andresen, No. 10.

Engraved after the painting by Titian. First state, Proof before all LetTers. Splendid impressionperfect condition. Margin one inch all around. Fine. From the collection of F. W. Klever.

VAN DALEN, CORNELIS

25\%. Sebastiano del Piombo. Engraving.

Andresen, No. 11.

Engraved after the painting by Tintoretto. First state, PROOF Before ALL LETters. SPlendid impression iN PERfECT CONDition. Cut just inside the plate-mark. Fine.

VAN DALEN, CORNELIS

258. Boccacio.

Le Blanc, No. 22.

Engraved after the painting by Titian. Proof before all letters. Superb impression in perfect condition. Margin 1/4 inch all around. Mounted down for framing. 


\section{CRISPIN VAN DE PASSE, THE ELDER}

Dutch line engraver. Born in 1540; died at Utrecht, 1629. He was a pupil of Coornhaert and worked in Holland, France, and England.

\section{VAN DE PASSE, CRISPIN, THE ELDER}

259. Queen Elizabeth. Engraving.

Engraved after the design by Isaac Olivier. Fine imPression in very good condition. Cut on the plate-line. VERY RARE.

From the Collections of William Esdaile and E. G. Kennedy.

\section{VAN DE PASSE, CRISPIN, THE ELDER}

260. Elizabeth of England. Engraving.

Splendid impression with inscription. Condition immaculate. Margin $1 \frac{1}{2}$ to 3 inches all around. VERY FIne.

From the Brooke and St. John Dent Collections.

Elizabeth of England. Engraving.

Engraved by an unknown artist. Oval picture with the motto "Posi u Deum Adiutorem meum." Good impression, in good condition.

From the Capt. Donnadieu Collection.

Together, 2 pieces.

\section{SIMON VAN DE PASSE}

Dutch line engraver. Born in Cologne in 1574; died, 1644. He was son and pupil of Crispin, the elder, and worked in France, Germany, England, and Denmark.

\section{VAN DE PASSE, SIMON}

261. Robert Sidney, Viscount Lisle. Engraving.

Splendid impression with inscription. First state.

Condition very good. Cut on the plate-mark. VErY FINE AND RARE.

On the back of the print is written,-_From Strawberry Hill," implying, perhaps, that it was formerly in the possession of Horace Walpole. 
Second Session, Wednesday Evening, A pril 11th

VAN DE PASSE, SIMON

262. Henry, Earl of Southampton. Engraving.

Splendid impression with inscription. Condition practically perfect. A few slight thin places. Fine and RARE.

From the collection of Joseph Crawhall.

Henry, Earl of Southampton, patron of Shakespeare, was born in 1573 and died in 1624 .

VAN DE PASSE, SIMON

263. Maria, Infanta of Spain. Engraving.

Very fine impression with inscription. Condition PerFECT. Cut on the plate-line.

The Princess Wilhelmina. Engraving.

Printed by Crispin de Passe. Good impression with inscription. Condition perfect. Cut outside platemark on side, and inside at top and bottom.

Together, 2 pieces.

VAN DE PASSE, SIMON

264. Edward Somerset, Earl of Worcester. Engraving.

Fine impression with inscription. Condition perfect. Cut on the plate-line.

Pope Clement VIII. Engraving.

Fine impression with letter. Condition perfect. Margin $1 / 4$ inch all around.

Francis Bacon. Engraving.

Fine impression with inscription. Condition perfect.

Margin 1/16 inch all around.

Together, 3 pieces. 
Second Session, Wednesday Evening, April 11th

\section{JOHN VANDERVAAR'T}

Born at Haerlem, 1647, went to England in 1674. Practised as a painter with Wyck and Wissing, afterwards produced very excellent pictures. He was one of the early engravers in mezzotinto. He died in 1721.

\section{VANDERVAART, JOHN}

265. Sir Thomas Killigrew. Mezzotint.

Smith, No. 4.

Engraved after the painting by W. Wissing. FIrst state, before the publisher's name was changed. Splendid impression. Surface and condition perfect. Cut outside plate-mark.

"Born 1611; page of honor to Charles I and groom of the bedchamber to Charles II, whom he accompanied in exile. He was the author of several plays and possessed uncommon wit and humor. He died in 1682."-J. c. sMIтH.

\section{LUCAS VAN LEYDEN}

Born in Leyden in 1494; died in 1533. His engravings rank with those of Marc Antonio and Albert Dürer.

\section{VAN LEYDEN, LUCAS}

266. Adam and Eve. Engraving.

Bartsch, No. 11.

Signed on the plate with the monogram,-“ “L." Engraved after his own design in 1510. Fine impression, on paper watermarked with "The Serpent." Cut slightly inside the plate-mark at the top. Margins reinforced. Condition otherwise perfect.

From the collection of Louis Galichon.

\section{ADRIAEN VAN OS'TADE}

Dutch painter and etcher. Born at Haerlem in 1610; died there in 1685 . Studied with Frans Hals and was influenced by Rembrandt.

"Ostade treats the technique of etching in a curious painter-like manner. He avoids the distinct line and the definite contour, he expresses the modelling with masses of uneven little strokes and shows his figure, well lighted against a dark background."-KRISTELLER, in "Küpferstich und Holzschnitt."

\section{VAN OSTADE, ADRIAEN}

267. Rustic Courtship. Etching.

Bartsch, No. 11.

Fine impression of the state after the S. of Ostade was 
[No. 267-Continued]

written with a Latin letter. Condrtion perfect. Margin $1 / 8$ inch all around.

From the collection of the Duke of Buccleugh.

\section{PAUL VAN SOMER}

Engraver, born at Amsterdam in 1649. After working for some time in Paris he came to England, where he settled and died in 1694 . He etched, engraved, and was one of the first to practice mezzotint.

\section{VAN SOMER, PAUL}

268. Hortense, Duchess of Mazarin. Mezzotint.

Smith, No. 7.

Splendid impression. Surface and condition fair. Cut on the plate-line. VerY rare.

\section{VAN SOMER, PAUL}

269. Louise, Duchess of Portsmouth. Mezzotint.

Smith, No. 14.

Engraved after the painting by Sir Peter Lely. First state, proof before all letters. Splendid impression. Surface and condition perfect. Cut just outside plate-mark. Very fine.

Louise Renée de Queronalle was of a noble family in Brit$\operatorname{tany}$. She attracted the attention of Charles II. and was brought to Whitehall (with the connivance of the Duke of Buckingham and others who wished to supplant the Duchess of Cleveland), and appointed maid-of-honor to the Queen. In 1672 she had a son by Charles, and in $\mathbf{1 6 7 3}$ was created Duchess of Portsmouth. Her power over Charles only ceased with his life and her extravagance was boundless. Much of the popularity of Nell Gwyn while mistress to the king was attributable to the aversion caused by her rival, the Duchess of Portsmouth. 


\section{LUCAS VAN UDEN}

Lucas van Uden, of the School of Flanders, was born at Antwerp in 1595 . He was the son of a painter, who was his first master and whom he very quickly surpassed.

"Van Uden has a delicate touch, and his foliage a great deal of movement. His landscapes usually show a great extent of country, with clear skies and distances. . . .

"The prints which this painter has left us and which are usually landscape subjects have all the qualities of his pictures. The exact number of his plates has not been determined. It is the rarest thing in the world to find any considerable number of them together. The greatest collections contain only about twenty or at the most thirty pieces."-BARTsCH.

\section{VAN UDEN, LUCAS}

2\%0. Landscape. Etching.

Bartsch, No. 5 .

Signed on the plate,_-"Lucas Van Uden fecit." Fine IMPRESSION IN PERFECT CONDITION.

From the Gawet and Rechberger collections.

Laxdscape. Etching.

Bartsch, No. 19.

Unsigned. First state, before the number. Fine imPrEssion in very good condition. One slight mended tear.

Together, 2 pieces.

\section{AGOS'TINO VENEZIANO}

Italian engraver, born at Venice in 1490. He was a pupil of G. Campagnola, but afterwards formed his style on that of Dürer and Marcantonio. He died at Rome about 1540 .

\section{VENEZIANO, AGOSTINO}

2\%1. The Death of Axanias. Engraving.

Bartsch, No. 42.

Engraved after the design by Raphael. Good impression, is Perfect condition. Cut just outside the plate-line. From the M. M. Sykes, W. Esdail, J. Thorel and A. Firmin-Didot collections.

Together with a late impression from the same plate, and the engraving, "La Bataille an Bouclier sur la Lance," by Caraglio after Raphael (Bartsch, No. 59), in a late impression.

Together, 3 pieces. 
Second Session, Wednesday Evening, A pril 11th

\section{JAN VERKOLJE}

Dutch engraver. Born at Amsterdam in 1650; died, 1693. He worked mostly at Delft, where he produced mezzotints.

VERKOLJE, JAN

272. The Duchess of Grafton. Mezzotint.

Smith, No. 1.

Engraved after the painting by Sir Peter Lely. First state, before the name, P. Lely, was erased. RICH Impression. Fine surface and condition. One or two slight printer's folds. Cut on the plate-line and margins strengthened. Of the utmost rarity; Smith speaks of only one in existence.

\section{GEORGE VERTUE}

English historical engraver and mezzotinter. Born, 1684; died at London, 1756. Devoted his life to antiquarian researches.

\section{VERTUE, GEORGE}

273. Geoffrey Chaucer. Engraving.

Engraved in 1717. Good Impression. Margin 1/16 to $1 / 8$ inches. Mounted down for framing. VERY RARE.

\section{VERTUE, GEORGE}

274. Alexande B Pope. Engraving.

Signed on the plate,-“Geo. Vertue sculpsit." Brilliant IMPRESSION IN PERFECT CONDITION. Margin $1 / 8$ inch all around.

Abraham Cowley. Engraving.

Engraved after the painting by Sir Peter Lely. Goov impression with letters. IN PERFEct condition. Cut on the plate-mark.

Together, 2 pieces. 


\section{W. VINCEN'T}

An excellent English mezzotint engraver, worked in London in the latter part of the 17th century. His plates are frequently from his own designs.

VINCENT, W.

275. Mrs. Bracegirdle in the Indian Queen. Mezzotint.

Smith, No. 1.

Published by J. Smith. Only state. Fine impression. Surface and condition perfect. Margin 1/16 inch all around. VERY RARE.

The play of the Indian Queen was written by Sir Howard and Dryden and met with great success.

VINCENT, W.

276. Mrs. Bracegirdle. Mezzotint.

Smith, No. 2.

Engraver's proof before the title, The Indian Queen. Fine impression in perfect condition. Cut perhaps inside plate-mark. Excessively rare, only one other impression known to Smith.

\section{CORNELIS VISSCHER}

One of the most eminent engravers, whose plates rank among the best productions of the graver. Born, about 1629; died, 1658. Pupil of Pieter Soutman.

\section{VISSCHER, CORNELIS}

277. Cornelis Visscher. Engraving.

Smith, No. 84.

Engraved after his own design and signed on the plate,-

"Corn. Vischer fecit An. 1649." Second state, with the graver effaced. VERY FiNE IMPRESSION IN PERFECT CONDition. Margin 1/16 inch all around. 


\section{VISSCHER, CORNELIS}

278. Lieven van Coppenol. Engraving.

Smith, No. 93.

Engraved from life. Fine impression with inscription. Third state, before the date 1658 was effaced. Margin cut slightly inside the plate-mark. It is interesting to compare this with Rembrandt's etching of the same subject.

From the collections of Pierre Mariette, 1698, and J. Burleigh James.

\section{VISSCHER, CORNELIS}

279. Head of an Old Woman. Etching.

Smith, No. 129.

Signed on the plate,-“Cornelius de Vesscher ad vivum delineant et fecit aqua forte." Good IMPRESSION IN PERFECT condition. Cut on the plate-line.

Tradition has it that this is a portrait of Visscher's mother.

\section{JAN VISSCHER}

Dutch engraver. Brother of Cornelis Visscher. Born at Amsterdam in 1636, where he lived in 1692.

\section{VISSCHER, JAN}

280. Portrait of ax Old Woman (Visscher's Mother?). Etching Etched after the design by Cornelis Visscher. Splendid impression in PERFECT Condition. Cut outside the plate-mark.

From the collection of the engraver Jean Georges Wille, and bearing his autograph,-“J. G. Wille 1761." 


\section{LUCAS VORS'TERMAN}

Flemish engraver. Born in Antwerp in 1578; died about 1656. He first studied painting under Rubens and was advised by him to take up the practice of engraving. This he did with such success that he became one of the leading engravers of the Rubens school.

\section{VORSTERMAN, LUCAS}

281. Joannes Waverius. Engraving.

Engraved after the painting by Hans Holbein. Very fine impression with letters. Perfect condition. Margin 1/2 inch all around.

\section{VORSTERMAN, LUCAS}

282. Thomas Howard, Duke of Norfolk. Engraving.

Engraved after the painting by Hans Holbein. Third state. Splendid impression. Perfect condition. Margin 1/16 inch all around. Of unusual quality.

From the collections of $\mathrm{T}$. Huber and Ambrose FirminDidot.

\section{WILLIAM WALKER}

Scotch engraver. Born in Midlothian in 1793; died in 186\%. Studied under John Mitchell, Woolnoth and Thomas Lupton. He published his own plates.

\section{WALKER, WILLIAM}

283. Sir Walter Scott. Engraving.

Engraved after the painting by Raeburn. Proof, with coat-of-arms, but before all letters. Splendid impression on INdia paper with full margins. Very fine AND RARE.

The engraver commissioned the painter to make this portrait of Scott. 


\section{JAMES WATSON}

"James Watson, born at Dublin about 1740, also learned from McArdell the true pictorial way of mezzotint, which, with facile craftsmanship, enabled him to become very early in his career one of Reynolds's most faithful and frequent interpreters (it is curious to note that Watson was selected to engrave Reynolds's portraits of mothers with their children). His touch was delicate rather than vigorous, and his sense of tone was keen for rich as for simple harmonies. An assiduous worker, he was so scrupulous as to the quality of his work, that if it did not satisfy him he would destroy the plate and start a fresh one. Consistency of quality therefore stamped the numerous plates of James Watson, as prosperity brightened his home, till he died in the very prime of his powers; but in nothing was he happier than in his gifted daughter Caroline, who holds among the stipple engravers as distinguished a place as her father does among mezzotinters."-м. c. salanan, Old English Mezzotints.

WATSON, JAMES

284. Frances, Lady Bridges. Mezzotint.

Smith, No. 14.

Engraved after the painting by F. Cotes. State indeterminate. Trimmed to engraved surface, and new lower margin added. Very fine impression. Surface good.

WATSON, JAMES

285. Samuel Johnsor. Mezzotint.

Smith, No. 82.

Engraved after the painting by Sir Joshua Reynolds. First state, before the title and the address. Splendid IMPREssion. Surface and condition practically perfect. Margin $1 / 8$ inch all around. VERY FINE AND RARE.

"This is also a highly characteristic and remarkable portrait"J. c. SMITH.

Johnson did not relish Reynolds painting him as extremely nearsighted, and said to Boswell,-_"Sir, he may paint himself as deaf as he chooses, but I will not go down to posterity as Blinking Sam.”

\section{[See Reproduction]}




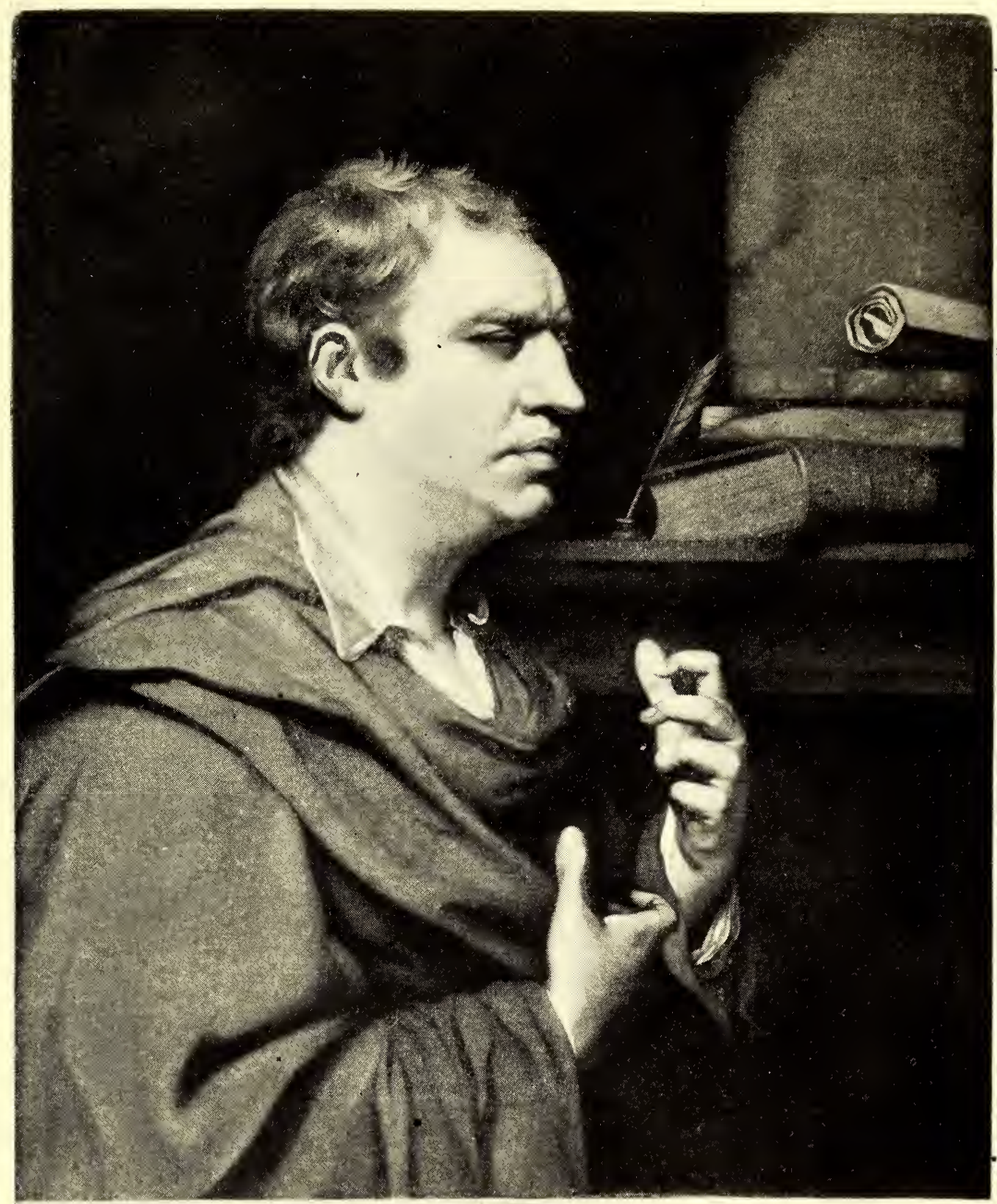

JAMES WATSON. MEZZO'TINT

Samuel Johnson

[No. 285] 


\section{THOMAS WATSON}

Mezzotint engraver. Born in London in 1743; died at Bristol, 1781. Apprenticed to an engraver on plate. For a time he kept a printshop in partnership with W. Dickinson. His name is one of the most distinguished of the English mezzotint engravers.

\section{WATSON, THOMAS}

286. Frances, Duchess of Richmond. Mezzotint. Smith, No. 5.

Engraved after the painting by Sir Peter Lely. SEcond state, before the name of the personage. VERY FINE IMPression. Surface and condition very good. Margin $1 / 16$ inch all around. Number three of a set of six "Beauties of Windsor," painted by Sir Peter Lely.

"Daughter of Walter Stewart; appointed maid of honor to Queen Catherine in 1663. Her wonderful loveliness seriously captivated Charles II and many others, amongst them Rotier, the medallist, who came over to cut the die for the new carriage and exhibited her head on the reverse as Britannia. She, however, eloped with the Duke of Richmond and I.ennox in 1667 .

"About two years after her marriage she was attacked by small-pox and recovered with difficulty. . . The King frequently visited her after her marriage, but merely in courtesy; . . . The Duchess appears to have divided the latter part of her life between cards and cats and died in 1702."- -

\section{JOHN WAT'TS}

An English mezzotint engraver who practised in London from 1770 to 1786. He was probably also a printseller.

WATTS, JOHN

287. Nathaniel Lee ('The Mad Poet). Mezzotint. Smith, No. 5.

Engraved after the painting by Dobson. ONLy state. Good impression. Surface and condition good. Margin cut just inside plate-line, and print completely laid down. 


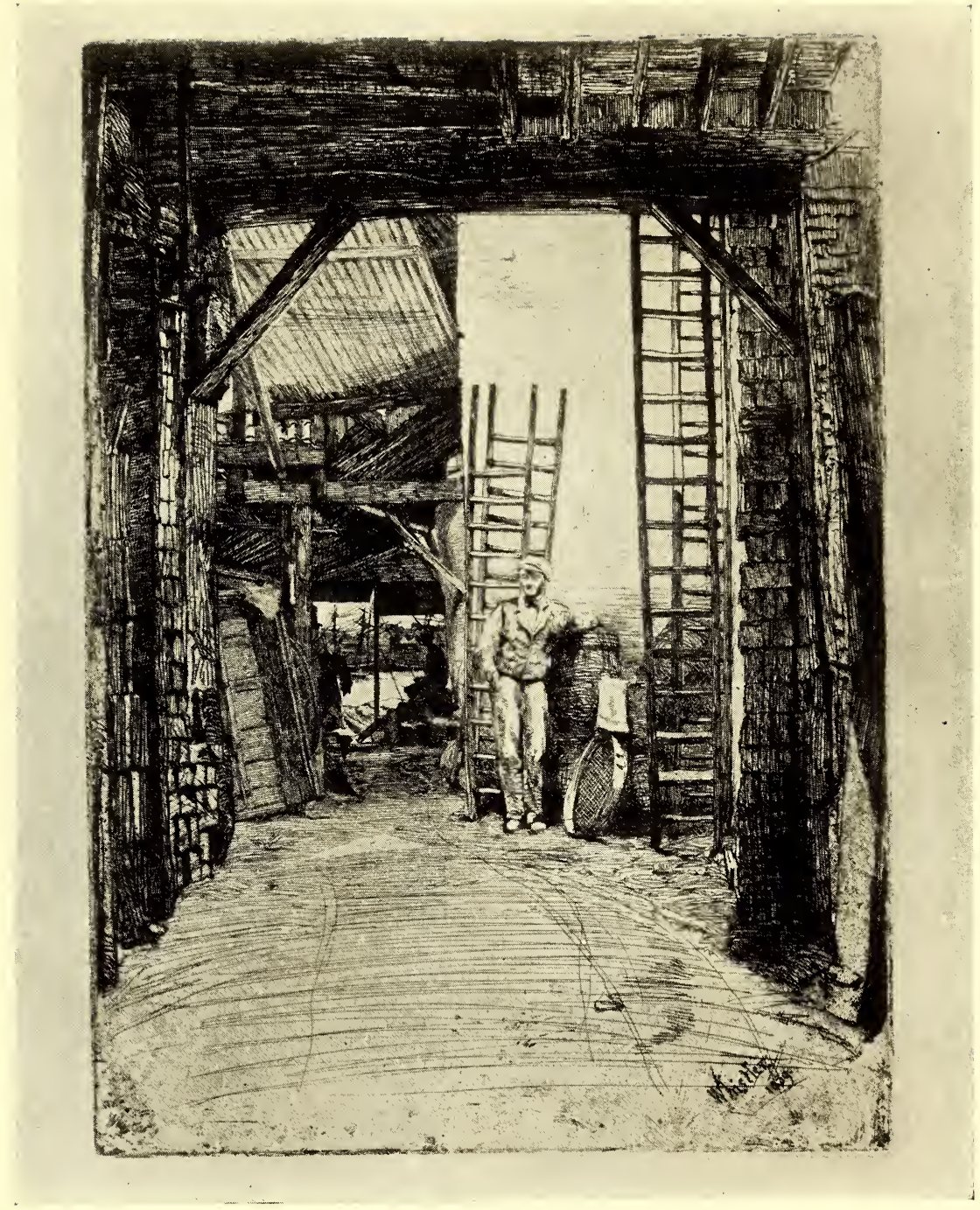

JAMES ABBO'TT MCNEILL WHISTLER. E'TCHING The Limeburner

[No. 288] 
Second Session, Wednesday Evening, A pril 11th

\section{JAMES ABBO'T'T MCNEILL WHISTLER}

Celebrated American painter and etcher. Born in Lowell, Mass., in 1834, died at London in 1903.

"With the master-etchers of the world-Meryon's equal in some respects, and, in some respects, Rembrandt's-there stands James Whistler. Connoisseurs in France and England, in America, Holland, Bavaria, concede this now."-FREDERICK WEDMORE.

"All his work is alike perfect. It has only been produced under different circumstances and is an attempt to render different effects or situations. Therefore the methods vary, but the results are always the same-great. The greatest, most perfect, as a whole, that any etcher has ever accomplished."-JOSEPH PENNELI.

\section{WHISTLER, JAMES ABBOTT McNEILL}

288. The Limeburner. Etching.

Kennedy, No. 46.

Signed on the plate,-“Whistler 1859." Finst state, before the light perpendicular lines to the right of the figure. Soft mellow impression. Condition very good. Surface of paper slightly broken by printing cracks. One inch margin all around. VERY FINE AND RARE.

One of the most beautiful of Whistler's plates and probably the earliest example of a system of composition which became very characteristic of him-that of a vista seen through a frame. Later examples of it are: The Traghetto, The Beggars, Doorway and Vine, San Biagio, and perhaps the last and frankest expression of all, The Garden. In these plates the foreground and middle distance are treated as an elaborate frame, for the most part in shadow, through which is seen a small and unusually brilliantly lighted distance."-FREDERICK KEPPELL.

\section{[See Reproduction]}

\section{WHISTLER, JAMES ABBOTT MCNEILL}

289. Rotherhithe. Etching.

Kennedy, No. 66.

Signed on the plate,-Whistler 1860." Second state, before additional lines on the figure and the bow of the boat. Superb impression on thin Japan paper. Margin $1 / 4$ inch all around. Exceedingly fine.

"This plate was made on the balcony of the Angel Inn, still standing on the south side of the river at Cherry Gardens. Rotherhithe is in the extreme distance. From this balcony also, the oils, Wapping, and The Thames in Ice, were painted. A scratch across the sky is in some prints. Whistler told me this was caused by a brick from the chimney being repaired falling behind him and making him jump so that he scratched the plate with his needle from top to bottom." JOSEPII PENNELL.

\section{[See Reproduction]}




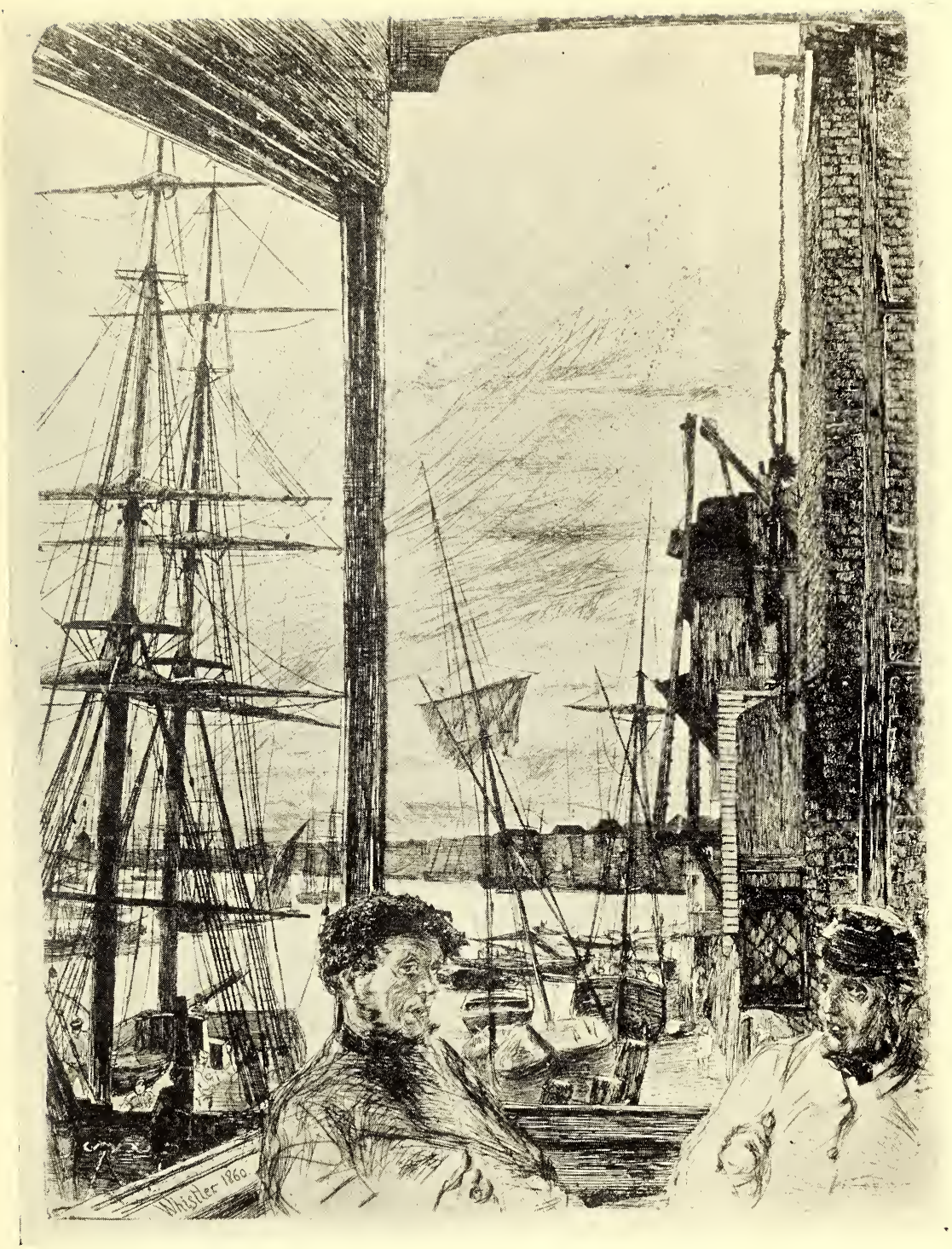

JAMES ABBOTT MCNEILL WHISTLER. E'TCHING Rotherhithe

[No. 289] 


\section{WHISTLER, JAMES ABBOTT McNEILL}

290. Battersea Bridge. Etching.

Kennedy, No. $17 \%$.

Signed on the plate and in pencil with the "Butterfly." Fourth state before the smaller butterfly was put in. IMPRESSION PRINTED BY WhISTER HIMSELF AND SO SIGNed BY HIM WITH A CAREFULLY DRAWN "BUTTERFLY" AND THE word "Imp." A very slight fold in the center. VERY RARE AND FINE.

"Il se mit tout simplement à reproduire à l'eau-forte les scenes que les rives de la Tamise mettaient sous ses yeux. En haut de la rivière, les vieux ponts de Putney et de Battersea, les appontements et les magasins ou se déchargent les marchandises, l'enfilade des allèges et des gabares à sec sur la rive; plus bas, vers le port maritime, les navires amarrés le long des docks ou les bateaux de peche apportant le poisson au grand marché de Billingsgate. Chose singulière! les bords de la Tamise ainsi reproduits frappèrent d'abord le public anglais, par un coté d'imprévu et de nouveaute. Les artistes anglais avaient négligé d'abaisser les yeux sur cet aspect familier des choses; le Londres, bati et affairé àait été méconnu comme vulgaire et prosaique."-THÉODORE DURET,-“Whistler et son Wurre."

\section{[See Reproduction $]$}

\section{ROBER'T WHI'TE}

Born in London, 1615; died at Bloomsbury, 1704. Pupil of David Loggan.

\section{WHITE, ROBERT}

291. John, Earl of Rochester. Engraving.

Engraving after the painting by Sir Peter Lely. Fine IMPREssion With LeTters. In perfect condition. One inch margin all around.

\section{JEROME WIERIX}

Born at Antwerp or Amsterdam, 1551; died in 1619. He is supposed to have learned the art of engraving from his brother $J a n$, whose style he followed so exactly that it is difficult to distinguish their work.

\section{WIERIX, JEROME}

292. Henry III. of France. Engraving.

Signed on the plate,-“Ieronimus W. fe." SPlendid ImPREssion in PERFECT Condition. Cut outside platemark. VERY FINE AND RARE.

\section{[See Reproduction $]$}




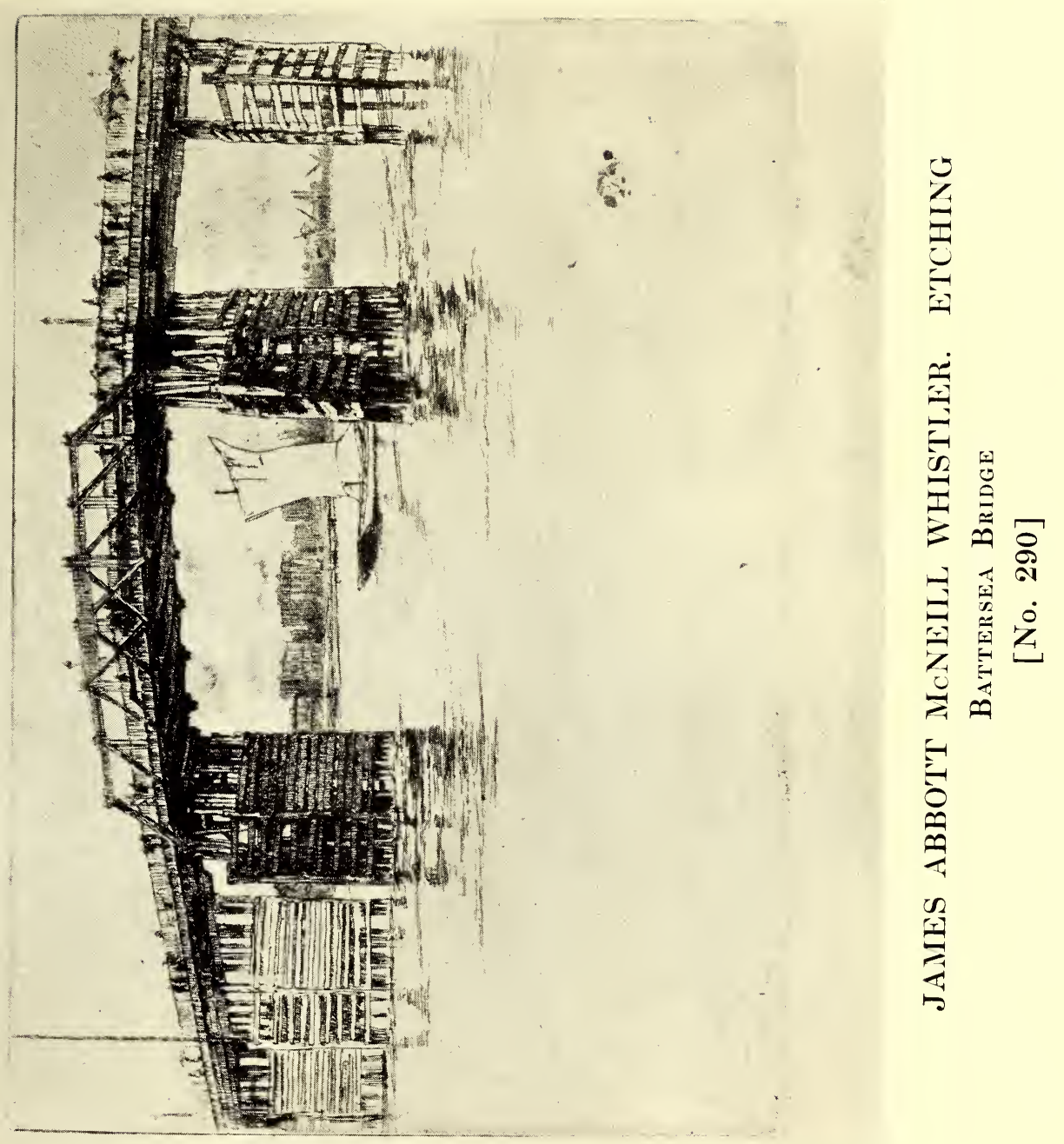




\section{SIR DAVID WILKIE}

Scotch painter and etcher. Born at Cults in 1785; died in 1841. He early displayed his talent for portraiture and painting and by rapid degrees became one of the most distinguished painters of his day. At the death of Sir Thos. Lawrence he was appointed Painter in Ordinary to the King.

\section{WILKIE, DAVID}

293. Readivg the Will. Etching.

Laing, No. 6.

Signed on the plate,- “ $D W$ 1819." Fine impression on India Paper. Condition perfect. Margin $1 / 2$ inch all around.

Cottage Exterior. Etching.

Laing, No. 4.

Signed on the plate,- “ $D W$ 1820." Fine impression on India Paper. Condition perfect. Margin $1 / 8$ to $3 / 4$ inch all around.

Together, 2 pieces.

WILKIE, DAVID

294. Moṭher ANd Child. Etching.

Laing, No. 9.

Signed on the plate,-“ $D W$ 1820." IMpression on INDIA PAPER, with full margins.

The Lost Receipt. Dry-point.

Laing, No. $\%$.

Remarque proof on India paper with full margins. IN PERFECT CONDITION.

Together, 2 pieces.

\section{JEAN GEORGES WILLE}

Born near Koenigsberg, 1714-1715; died at Paris, 1808.

"His prints bear dates from 1738 to 1790 , after which time he became blind. He was the teacher of Bervic, J. V. von Müller, Tardieu, and other eminent engravers."-w. o. CHAPIN.

\section{WILLE, JEAN GEORGES}

295. La Soeur de la Femme de Normandie. Engraving.

Le Blanc, No. 72 .

Engraved after the painting by his son, P. A. Wille. Proof before all letters. Brilliant impression in Perfect condition. Margin $1 / 8$ inch all around. Very FINE. 


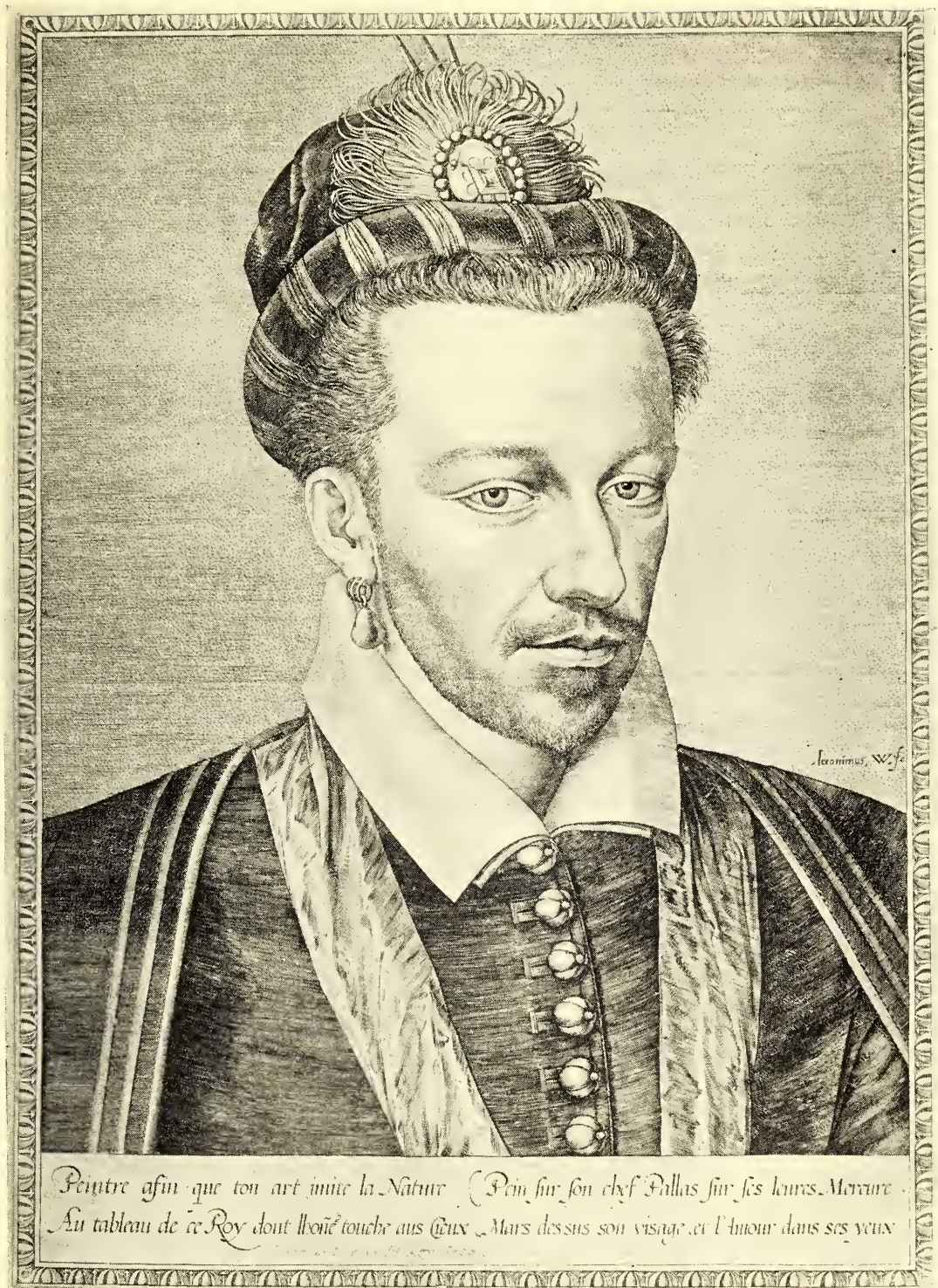

JEROME WIERIX. ENGRAVING

Henry III. of France

[No. 292] 
Second Session, Wednesday Evening, April 11th

\section{ROGER (OR ROBER'T) WILLIAMS}

Mezzotint engraver, a native of Wales, flourished about 1700-1715. He is stated to have studied under Theodorus Freres.

\section{WILLIAMS, ROGER (or ROBERT)}

296. Charles II. Mezzotint.

Smith, No. 12.

Engraved after the painting by Sir Peter Lely. Secord state, with inscription. Verr fine impression. Surface very good. Condition perfect. Margin $1 / 4$ inch all around.

\section{'THOMAS WOOLNO'TH}

English mezzotint engraver. Born 1785; died after 1836. He engraved many theatrical portraits.

\section{WOOLNOTH, THOMAS}

297. R. Heber, Bishop of Calcutta. Mezzotint.

Engraved after the painting by Phillips. EArLY TRIAL Proof, not completely inked. SPLENdid impression in PERFECT CONDITION.

\section{THOMAS WORLIDGE}

English painter and etcher. Born in 1700; died at Hammersmith, 1766. He abandoned painting and devoted himself to etching, adopting a style modelled on that of Rembrandt.

WORLIDGE, THOMAS

298. Ninon de Lenclos. Etching.

Engraved after the painting formerly in the possession of the Countess of Sandwich. Proof Before ALL LETters. In perfect condition. Cut on the plate-line.

\section{WILLIAM LIONEL WYLLIE}

Contemporary English etcher. Born, 1851. His etchings are chiefly boating and fishing scenes.

\section{WYLLIE, WILLIAM LIONEL}

299. Holland. Etching.

Signed ARTist's Proof on Holland paper. Mounted down for framing. Full margins. 


\section{JOHN YOUNG}

"Another of J. R. Smith's distinguished pupils was John Young, who was, however, senior to the Wards, having been born in 1755 . He was a man of high attainments and sterling character, with a fine pictorial sense in his treatment of copper. Engraver on mezzotint to the Prince of Wales, from 1789 he succeeded Valentine Green as keeper of the British Institution."-м. с. SALAman,-“The Old Engravers of England."

\section{YOUNG, JOHN}

300. Robert Bloomfield. Mezzotint.

Smith, No. 8.

Engraved probably after the painting by J. Rising. First state, undescribed by Smith. Proof before all letters. Splendid impression. Surface and condition perfect. Margin $1 / 2$ inch all around. Very fine and rare.

"Born at Honington, 1766; worked on a farm, and afterward became a shoemaker, his poem of the Farmer's Boy was long finding a publisher, but on its appearance met with great success. He died at Sheffield, 1823."- - c. c. sмiтн.

\section{RENIER NOOMS (CALLED ZEEMAN)}

1623-1663.

"Zeeman was par excellence the etcher of ships as Potter was of horses. In his youth he was a sailor, as his name implies, and his love for the sea is apparent everywhere in his works. Zeeman worked at Berlin, London, and Paris, as well as at Amsterdam. He was in Paris about the middle of the seventeenth century and painted a number of views of the city, among them his fine view of Old Louvre."-w. o. chapin,-_Masterpieces of Engraving."

\section{ZEEMAN, RENIER NOOMS (CALLED)}

301. Marine. Etching.

Bartsch, No. 110.

First state, before the name. Fine impression. Slightly folded. Margin $1 / 16$ inch all around. Fine AND RARE.

One of a set of 12 etchings. From two collections unknown to Fagan. 
Second Session, Wednesday Evening, April 11th

\section{WILLEM DE ZWART}

Contemporary Dutch etcher. Many of his etchings are published by E. J. Van Wisselingh, of Amsterdam.

ZWART, WILLIAM DE

302. The Barges, Evenisg. Etching.

Signed in ink on the margin,-—“ $W$ de Zwart." Proof on JAPAN PAPER, with margins.

Sleeping Woman. Etching.

Signed in ink on the margin,-_ "W de Zwart." Proof on HEAVY JAPAN PAPER, with ample margins.

Together, 2 pieces.

Immediately at the close of this sale will be sold three small but choice collections of etchings and engravings by Whistler, Haden, Dürer, Rembrandt van Rijn and other Masters.

AMERICAN ART ASSOCIATION,

Managers.

THOMAS E. KIRBY,

Auctioneer. 


\section{FOR INHERITANCE TAX}

AND OTHER PURPOSES

\section{The AMERICAN Art Association}

IS EXCEPTIONALLY WELL EQUIPPED

TO FURNISH

\section{INTELLIGENT APPRAISEMENTS}

OF

\section{ART AND LITERARY PROPERTY}

JEWELS AND PERSONAL EFFECTS OF EVERY DESCRIPTION

IN CASES WHERE

\section{PUBLIC SALES ARE EFFECTED}

A NOMINAL CHARGE ONLY WILL BE MADE

THE AMERICAN ART ASSOCIATION

MADISON SQUARE SOUTH NEW YORK

TELEPHONE, 3346 GRAMERCY 
COMPOSITION, PRESSWORK

AND BINDING BY

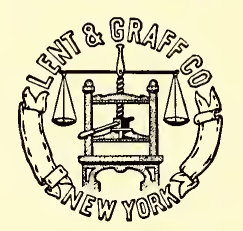



